\title{
The Unmaking of the Black Blue-Collar Middle Class
}

\author{
William Lazonick, Philip Moss and Joshua Weitz*
}

\author{
Working Paper No. 159
}

May $20^{\text {th }}, 2021$

\begin{abstract}
In the decade after the Civil Rights Act of 1964, African Americans made historic gains in accessing employment opportunities in racially integrated workplaces in U.S. business firms and government agencies. In the previous working papers in this series, we have shown that in the 1960s and 1970s, Blacks without college degrees were gaining access to the American middle class by moving into well-paid unionized jobs in capital-intensive mass production industries. At that time, major U.S. companies paid these blue-collar workers middle-class wages, offered stable employment, and provided employees with health and retirement benefits. Of particular importance to Blacks was the opening up to them of unionized semiskilled operative and skilled craft jobs, for which in a number of industries, and particularly those in the automobile and electronic manufacturing sectors, there was strong demand. In addition, by the end of the 1970s, buoyed by affirmative action and the growth of public-service employment, Blacks were

\footnotetext{
${ }^{\dagger}$ The authors are grateful to the Institute for New Economic Thinking for funding this project and to Thomas Ferguson for many insightful comments. Samantha Gable and Wynn Tucker provided research assistance.

${ }^{*}$ William Lazonick is emeritus professor of economics, University of Massachusetts Lowell, and president of the Academic-Industry Research Network; Philip Moss is emeritus professor of economics, University of Massachusetts Lowell, and a research associate at the Academic-Industry Research Network; Joshua Weitz is a Ph.D. candidate in political science at Brown University and a research associate at the Academic-Industry Research Network.
} 
experiencing upward mobility through employment in government agencies at local, state, and federal levels as well as in civil-society organizations, largely funded by government, to operate social and community development programs aimed at urban areas where Blacks lived.

By the end of the 1970s, there was an emergent blue-collar Black middle class in the United States. Most of these workers had no more than high-school educations but had sufficient earnings and benefits to provide their families with economic security, including realistic expectations that their children would have the opportunity to move up the economic ladder to join the ranks of the college-educated white-collar middle class. That is what had happened for whites in the postWorld War II decades, and given the momentum provided by the dominant position of the United States in global manufacturing and the nation's equal employment opportunity legislation, there was every reason to believe that Blacks would experience intergenerational upward mobility along a similar education-and-employment career path.

That did not happen. Overall, the 1980s and 1990s were decades of economic growth in the United States. For the emerging blue-collar Black middle class, however, the experience was of job loss, economic insecurity, and downward mobility. As the twentieth century ended and the twenty-first century began, moreover, it became apparent that this downward spiral was not confined to Blacks. Whites with only high-school educations also saw their blue-collar employment opportunities disappear, accompanied by lower wages, fewer benefits, and less security for those who continued to find employment in these jobs. The distress experienced by white Americans with the decline of the blue-collar middle class follows the downward trajectory that has adversely affected the socioeconomic positions of the much more vulnerable blue-collar Black middle class from the early 1980s.

In this paper, we document when, how, and why the unmaking of the blue-collar Black middle class occurred and intergenerational upward mobility of Blacks to the college-educated middle class was stifled. We focus on blue-collar layoffs and manufacturing-plant closings in an important sector for Black employment, the automobile industry from the early 1980s. We then document the adverse impact on Blacks that has occurred in government-sector employment in a financialized economy in which the dominant ideology is that concentration of income among the richest households promotes productive investment, with government spending only impeding that objective. Reduction of taxes primarily on the wealthy and the corporate sector, the ascendancy of political and economic beliefs that celebrate the efficiency and dynamism of "free market" business enterprise, and the denigration of the idea that government can solve social problems all combined to shrink government budgets, diminish regulatory enforcement, and scuttle initiatives that previously provided greater opportunity for African Americans in the government and civilsociety sectors.

\section{https://doi.org/10.36687/inetwp159}

JEL codes: D2, D3, G3, J0, L2, L6, N8, O3, P1

Key words: African American, employment relations, equal employment opportunity, unions, blue-collar, employment mobility, automobile industry, government employment, massincarceration industries. 


\section{From upward mobility to downward mobility}

In the decade after the Civil Rights Act of 1964, African Americans made historic gains in accessing employment opportunities in racially integrated workplaces in U.S. business firms and government agencies. Some of these employment opportunities were in professional, technical, and administrative occupations, for which higher education was a required qualification. Many were in white-collar clerical and sales positions, for which a higher education was not necessarily demanded. Most of the increased opportunities were in blue-collar craft (or skilled) and operative (or semiskilled) occupations, which demanded no more than a high-school diploma.

In the 1970s, a large portion of the Black population faced persistent poverty as residents of the "inner cities" to which they or their ancestors had migrated from the rural South over the previous half century. In the postwar decades, however, many Blacks found a pathway out of poverty by securing steady blue-collar employment in the burgeoning mass-production factories characteristic of the era. The construction of the U.S. government-funded interstate highway system from the late 1950s enabled industrial corporations to locate their production facilities in suburban areas. As large numbers of Blacks secured jobs in these suburban plants, they vacated the inner cities and took up residence closer by.

Coming into the 1960s, Blacks continue to face considerable discrimination in these workplaces, confined to the lowest-paid and least desirable unskilled jobs. Their employment was often made insecure through the denial to them of the seniority rights - first hired, last fired - that protected their white counterparts, who dominated the better-paid semiskilled and skilled occupations. During the 1960s and into the 1970s, however, under pressure from strong demand for massproduction labor and civil-rights legislation, the employment opportunities of blue-collar Blacks improved markedly. Particularly in workplaces of major corporations, in which union bargaining secured members stable employment, rising real earnings, health coverage, and defined-benefit pensions, blue-collar workers-including rising proportions of Blacks-could attain a living standard that placed them at the lower levels of America's broad and deep middle class.

As we documented in the previous working paper of our "Fifty Years After" project, in the 1970s, the lower level of that emerging Black middle class included millions of blue-collar workers, both male and female, in unionized business establishments. ${ }^{1}$ The widespread availability to Blacks of these employment opportunities, on what was approaching an equal footing with whites, created a foundation for upward intergenerational socioeconomic mobility from high-school-educated bluecollar worker to college-educated white-collar worker - a trajectory that from the 1940s the families of white Americans had followed into the nation's upper middle class.

\footnotetext{
${ }^{1}$ For the project, "Fifty Years After: Black Employment in the United States Under the Equal Employment Opportunity Commission," carried out by the Academic-Industry Research Network in collaboration with the Institute for New Economic Thinking, see William Lazonick, Philip Moss, and Joshua Weitz, "How the Disappearance of Unionized Jobs Obliterated an Emergent Black Middle Class,” Institute for New Economic Thinking Working Paper No. 1255, June 15, 2021, at https://www.ineteconomics.org/research/research-papers/how-the-disappearance-of-unionized-jobs-obliterated-an-emergentblack-middle-class. For a summary of the employment progress for Black in the 1960s and 1970s, see Joshua Weitz, William Lazonick, and Philip Moss, "Employment Mobility and the Belated Emergence of the Black Middle Class," Institute for New Economic Thinking Working Paper No. 143, January 2, 2021, pp. 26-33, at https://www.ineteconomics.org/research/researchpapers/employment-mobility-and-the-belated-emergence-of-the-black-middle-class.
} 
This unprecedented upward socioeconomic mobility for Blacks in the decade after the Civil Rights Act of 1964 is the core observation that animates the analysis of William Julius Wilson in his book, The Declining Significance of Race: Blacks and Changing American Institutions, first published in 1978. Wilson contends that the racial integration of the nation's major places of employment in the 1960s and first half of the 1970s dramatically reduced the importance of race in determining socioeconomic status in the United States. ${ }^{2}$ The drivers of this progress in race relations were the civil rights movement, symbolized by the creation in 1965 of the U.S. Equal Employment Opportunity Commission (EEOC), and a strong demand for semiskilled and skilled labor in the nation's mass-production industries. The 1960s was also a decade in which immigration to the United States was at a record low. Millions of African Americans with no more than high-school educations were able to secure unionized blue-collar employment with good wages and benefits at the major mass-producing corporations.

At the same time, the offspring of many white blue-collar workers were taking advantage of relatively inexpensive higher education, especially in the public-university system, to make the intergenerational transition to college-educated white-collar employment opportunities. Increasing numbers of African Americans were also becoming college educated, and occupations and workplaces that required higher education were becoming more integrated. But, given the history of employment segregation and discrimination that Blacks had experienced since the end of slavery a century earlier, the most important socioeconomic progress that African Americans attained in the decade after the Civil Rights Act of 1964 was by means of expanded employment as blue-collar workers.

In a book, The New Black Middle Class, published in 1987, Bart Landry, like Wilson, sees the remarkable economic progress of Blacks in the 1960s as a potential foundation for sustained upward socioeconomic mobility for African Americans. ${ }^{3}$ Landry argues that, unlike the old Black middle class, which was created within largely segregated African American communities, the new Black middle class emerged within an increasingly integrated society. He recognizes that, previously, a major constraint on upward intergenerational socioeconomic mobility for the Black middle-class family was " $\mathrm{t}]$ he inability to pass on its position to its offspring that characterized the old black middle class." He observes that, in 1962, only 1 in 10 Black middle-class males came from the middle-class families, compared to 4 in 10 of whites. "By contrast," Landry argues, "the new black middle class was one with greatly enhanced opportunities, giving new meaning to middle-class origins for blacks." ${ }^{5}$

Landry posits that the socioeconomic segregation of African Americans "might have continued indefinitely had it not been for the development of two simultaneous and powerful forces within American society: prosperity and the civil rights movement. The chance simultaneous occurrence of these two factors created the necessary conditions for the emergence of a new black middle class." As he reiterates the basic proposition: "The uniqueness of the 1960s lay in the fact that

\footnotetext{
${ }^{2}$ William Julius Wilson, The Declining Significance of Race: Blacks and Changing American Institutions, University of Chicago Press, 1978.

${ }^{3}$ Bart Landry, The New Black Middle Class, University of California Press, 1987.

${ }^{4}$ Ibid., p. 88 .

${ }^{5}$ Ibid., p. 87.

${ }^{6}$ Ibid., p. 70 (emphasis in original).
} 
prosperity and the civil rights movement, culminating in equal employment opportunity laws, coincided. This was not the case in the 1950s or the 1970s."7

From this perspective, both Landry and Wilson recognize the precariousness of the upward socioeconomic mobility that African Americans had achieved by the 1970s. Landry, whose book was published almost a decade later than Wilson's The Declining Significance of Race, witnesses that vulnerability play out in the double-dip recessions of 1980-1982, which "dashed the optimism felt in 1976 by black and white alike....In the sobering postrecession climate of the mid-1980s, there is little talk about reaching the best imaginable life in the next five years." ${ }^{8}$ By the mid-1980s, Blacks had left the "fast lane" of upward mobility to find themselves "caught up in an economic traffic jam instead."9 The conclusion to Landry's book is decidedly pessimistic:

The schism in the economy between the white-collar service sector and the bluecollar productive and unskilled service sectors is deep and structural. Growth at the middle-class level no longer implies a corresponding decline in the number of unskilled workers and underclass individuals. The emergence of the black middle class, then, is a hopeful sign in the history of blacks in America. It is not a sign that all is well. ${ }^{10}$

In The Declining Significance of Race, Wilson argues that the marked progress in the upward socioeconomic mobility of African Americans in the 1960s was the result of

the shifts in the economy leading to a segmented labor structure have resulted in blacks either being isolated in the low-wage labor market and being concentrated in nonunionized, low-paying, basically undesirable jobs that nobody really wants or readily accepts, or being part of the higher-paying corporate and government industry labor market and thus being protected by powerful unions which effectively control job competition or have rigorous prerequisites that eliminate the poorly trained and educated regardless of race. ${ }^{11}$

Given this labor-market segmentation, Wilson, observing trends in the early 1970s, is not sanguine about the continued movement of poor Blacks out of the inner cities. As he puts it:

Although the changes in the black occupational structure since 1940 quite clearly show a consistent pattern of job upgrading, there are firm indications, as I have emphasized, that in the period of modern industrialization, the chances of continued economic improvement for the black poor are rapidly decreasing....[T]he effects of the advanced industrial, segmented labor market can be gauged by examining the rapid increase in the educational level of workers in the lower-paying occupations (unskilled laborers, service workers, semiskilled operatives) in which blacks are heavily concentrated. This means that persons with only a high school education or less may be increasingly consigned to the most

\footnotetext{
${ }^{7}$ Ibid., p. 73.

${ }^{8}$ Ibid. p. 230.

${ }^{9}$ Ibid., p. 233.

${ }^{10}$ Ibid.

${ }^{11}$ Wilson, The Declining Significance of Race, p. 110.
} 
inferior jobs. There is already an indication that the movement of blacks out of lower-paying to higher-paying jobs has slowed considerably in the 1970 s...[T]he rate of black occupational upgrading from 1970 to 1974 is considerably below that of 1964 to $1970 .{ }^{12}$

Wilson notes the disturbing facts that "female heads of poor black households increased from 56 percent in 1970 to 67 percent in 1974, and 75 percent of poor black female-headed families received some or all of their income from public assistance in $1973 .{ }^{13}$

In When Work Disappears: The World of the New Urban Poor, published in 1996, Wilson analyzes the actual unfolding of the pessimistic prognosis for Black upward mobility that he had perceived two decades earlier. ${ }^{14} \mathrm{He}$ lays the blame on the disappearance of blue-collar employment opportunities in unionized mass-production jobs that had enabled high-school-educated Blacks to climb to the lower rungs of the American middle class. "Of the changes in the economy that have adversely affected low-skilled African-American workers," Wilson argues, "perhaps the most significant have been those in the manufacturing sector." ${ }^{15}$ He observes that "[e]ven the low-skilled workers who are consistently employed face problems of economic advancement. Job laddersopportunities for promotion within firms - have eroded, and many less-skilled workers stagnate in dead-end, low-paying positions." 16

In the declining U.S. mass-production system, Wilson continues, "plenty of blue-collar jobs were available to workers with little formal education. Today, most of the new jobs of workers with limited education and experience are in the service sector, which hires relatively more women." 17 The drop in unionization rates translates into "shrinking wages and nonwage compensation for less skilled workers." 18 Wilson cites data that show a dramatic fall in the proportion of employed Black males ages 20-29 working in manufacturing industries from about 38 percent in 1973 to 20 percent in 1987, while those of this demographic group working in the retail trade and service jobs, in which annual earnings were 25-30 percent less than in manufacturing, rose from 17 percent to 27 percent and 10 percent to 21 percent, respectively, over these 14 years.

In this paper, we analyze this transition from upward to downward socioeconomic mobility for high-school-educated African Americans from the 1980s. In the previous papers in this series, we have shown that in the 1960s and 1970s, Blacks without college degrees were gaining access to the American middle class by moving into well-paid unionized jobs in capital-intensive mass production industries. At that time, major U.S. companies paid these blue-collar workers middleclass wages, offered stable employment, and provided employees with health and retirement benefits. Of particular importance to Blacks was the opening up to them of unionized semiskilled operative and skilled craft jobs, for which in a number of industries, and particularly those in the automobile and electronic manufacturing sectors, there was strong demand. While total employment in the steel sector had been declining from the 1960s, in the 1970s it was still a source

\footnotetext{
${ }^{12}$ Ibid., pp. 129-130.

${ }^{13}$ Ibid, pp. 130, 132.

${ }^{14}$ William Julius Wilson, When Work Disappears: The World of the New Urban Poor, Alfred A, Knopf, 1996. See especially Chapter 2: Societal Changes and Vulnerable Neighborhoods.

${ }^{15}$ Ibid, p. 29.

${ }^{16}$ Ibid, p. 25.

${ }^{17}$ Ibid., pp. 26-27.

${ }^{18}$ Ibid., p. 28.
} 
of well-paid unionized blue-collar jobs to which Blacks increasingly had access. In addition, and of considerable importance, by the end of the 1970s, buoyed by affirmative action and the growth of public-service employment, Blacks were experiencing upward mobility through employment in government agencies at local, state, and federal levels as well as in civil-society organizations, largely funded by government, to operate social and community development programs aimed at urban areas where Blacks lived.

As a result, by the end of the 1970s, there was an emergent blue-collar Black middle class in the United States. Most of these workers had no more than high-school educations but had sufficient earnings and benefits to provide their families with economic security, including realistic expectations that over the coming decades their children would have the opportunity to move up the economic ladder to join the ranks of the college-educated white-collar middle class. That is what had happened for whites in the post-World War II decades, and given the momentum provided by the dominant position of the United States in global manufacturing and the nation's equal employment opportunity legislation, there was every reason to believe that Blacks would now experience intergenerational upward mobility along a similar education-and-employment career path.

That did not happen. Overall, the 1980s and 1990s were decades of economic growth in the United States. For the emerging blue-collar Black middle class, however, the experience was job loss, economic insecurity, and downward mobility. As the twentieth century ended and the twenty-first century began, moreover, it became apparent that this downward spiral was not confined to Blacks. Whites with only high-school educations also saw their blue-collar employment opportunities disappear, accompanied by lower wages, fewer benefits, and less security for those who continued to find employment in these jobs. ${ }^{19}$ The distress experienced by white Americans with the decline of the blue-collar middle class follows the downward trajectory that has adversely affected the socioeconomic positions of the much more vulnerable blue-collar Black middle class from the early 1980 s.

In this paper, we document when, how, and why the unmaking of the blue-collar Black middle class occurred and intergenerational upward mobility of Blacks to the college-educated middle class was stifled. We focus on blue-collar layoffs and manufacturing-plant closings in, as an important sector for Black employment, the automobile industry from the early 1980s. We then document the adverse impact on Blacks that has occurred in government-sector employment in a financialized economy in which the dominant ideology is that concentration of income among the richest households promotes productive investment, with government spending only impeding that objective. Reduction of taxes primarily on the wealthy and the corporate sector, the ascendancy of political and economic beliefs that celebrate the efficiency and dynamism of "free market" business enterprise, and the denigration of the idea that government can solve social problems all

\footnotetext{
${ }^{19}$ Brian C. Thiede and Shannon M. Monnat, "The Great Recession and America's Geography of Unemployment," Demographic Research, 30, Article 35, 2016: 891-928; Susan B. Glasser and Glenn Thrush, "What's going on with America's white people?" Politico, September/October 2016, at https://www.politico.com/magazine/story/2016/09/problems-white-peopleamerica-society-class-race-214227; Brian Alexander, Glass House: The 1\% Economy and the Shattering of the All-American Town, St. Martin's Press, 2017; Anne Case and Angus Deaton, "Mortality and Morbidity in the $21^{\text {st }}$ Century," and "Comments and Discussion," Brookings Papers on Economic Activity, Spring 2017: 397-476; Raj Chetty, David Grusky, Maximilian Hell, Nathanial Hendren, Robert Manduca, and Jimmy Narang, "The Fading American Dream: Trends in Absolute Income Mobility since 1940," Science, 356, 6336, 2017: 398-406; William Lazonick, "Book review of Glass House: the 1\% and the Shattering of the All-American Town," Industrial and Labor Relations Review, 70, 5, 2017: 1285-1287.
} 
combined to shrink government budgets, diminish regulatory enforcement, and scuttle initiatives that previously provided greater opportunity for African Americans in the government and civilsociety sectors.

\section{Employment and earnings of Blacks in the 1960s and 1970s}

As a prelude to our analysis of the unmaking of the Black blue-collar middle class from the 1980s, let us review the employment and earnings progress that African Americans made in various broad occupational categories in the 1960s and 1970s. The eleven occupational categories in Table IV.1 are ranked, generally, from top to bottom by, in descending order, by educational requirements and earnings potential. In the middle is the "Operatives, including Transport" category, which has by far the most Blacks employed in 1970 .

The quality of these operative positions, in terms of employment security, job ladders, wage levels, and types of benefits, varied significantly by industry value-added, company productivity, and inhouse employment relations. As shown in the data in Table IV.2 on median annual earnings by broad occupational category in 1969 for family heads in the U.S. labor force (including all races), operative pay was significantly higher than laborer pay, especially in the 25-34 and 55-64 age brackets. Depending on the distribution of operative earnings around the median, the employment circumstances of any given operative might have provided annual earnings high enough for "middle class" status. Alternatively, a particular operative job may have entailed much lower annual earnings, typical of the "working class."

Of course, the class labels are unimportant except insofar as they signify different levels of employment security (e.g., union-protected seniority), career opportunity (e.g., the possibility for transitioning from a semiskilled operative job to a skilled craft job), and earnings potential (e.g., the difference between being an operative in a low-productivity garment factory or a highproductivity automobile factory). The key point is that, under propitious conditions, employment as a semiskilled operative circa 1970 offered a good standard of living to a member of the U.S. labor force. Blacks were far more likely to benefit from those propitious conditions at the end of the 1960 s than had been the case a decade earlier. 
Table IV.1: Blacks in the U.S. labor force by occupational category, 1960-2019

\begin{tabular}{|c|c|c|c|c|c|c|c|}
\hline \multirow[b]{2}{*}{ Occupation } & \multicolumn{7}{|c|}{ Number of Blacks in Occupational Category (000s) } \\
\hline & 1960 & 1970 & 1980 & 1989 & 2000 & 2010 & 2019 \\
\hline Total Black employment & 6,941 & 8,445 & 10,890 & 11,958 & 15,313 & 15,532 & 19,381 \\
\hline Managers and Administrators & 180 & 296 & 566 & 846 & 1,503 & 2,105 & 2,266 \\
\hline Professional and Technical & 332 & 768 & 1,383 & 1,373 & 2,328 & 2,834 & 3,910 \\
\hline Sales & 104 & 177 & 316 & 900 & 1,438 & 1,508 & 1,745 \\
\hline Clerical & 506 & 1,115 & 2,004 & 2,099 & 2,564 & 2,256 & 2,579 \\
\hline Craft & 416 & 692 & 1,045 & 1,092 & 1,191 & 821 & 1,047 \\
\hline Operatives, including Transport & 1,413 & 2,001 & 2,113 & 1,918 & 1,993 & 2,254 & 3,148 \\
\hline Nonfarm laboresr & 949 & 870 & 751 & 802 & 833 & 725 & 104 \\
\hline Private household & 984 & 650 & 348 & 219 & 118 & 660 & 856 \\
\hline Service, except Private household & 1,212 & 1,545 & 2,167 & 2,518 & 3,186 & 2,365 & 3,653 \\
\hline Farmers and Farm managers & 222 & 84 & 33 & 10 & 10 & 1 & 1 \\
\hline \multirow[t]{2}{*}{ Farm laborera and supervisors } & 623 & 245 & 163 & 182 & 150 & 4 & 43 \\
\hline & \multicolumn{7}{|c|}{ Blacks as a Percentage of Occupational Category } \\
\hline Occupation & 1960 & 1970 & 1980 & 1989 & 2000 & 2010 & 2019 \\
\hline Blacks as \% of all employees & 10.5 & 10.7 & 11.2 & 9.3 & 10.2 & 9.4 & 12.3 \\
\hline Managers and Administrators & 2.6 & 3.6 & 5.2 & 5.7 & 7.6 & 8.1 & 8.4 \\
\hline Professional and Technical & 4.5 & 6.9 & 8.9 & 7.2 & 9.1 & 9.2 & 10.5 \\
\hline Sales & 2.5 & 3.6 & 5.1 & 6.4 & 8.8 & 9.8 & 11.2 \\
\hline Clerical & 5.2 & 8.1 & 11.1 & 11.4 & 13.7 & 12.5 & 14.5 \\
\hline Craft & 4.9 & 6.8 & 8.3 & 7.9 & 8.0 & 6.8 & 7.9 \\
\hline Operatives, including Transport & 11.8 & 14.4 & 15.3 & 14.6 & 15.5 & 13.9 & 16.9 \\
\hline Nonfarm laborers & 26.8 & 23.2 & 16.8 & 16.4 & 15.3 & 13.6 & 8.2 \\
\hline Private household & 49.6 & 41.6 & 33.5 & 25.1 & 14.9 & 18.2 & 19.9 \\
\hline Service, except Private household & 20.1 & 19.0 & 18.2 & 17.2 & 18.2 & 14.8 & 17.1 \\
\hline Farmers and Farm managers & 8.1 & 4.8 & 2.2 & 0.8 & 0.9 & 0.6 & 1.2 \\
\hline \multirow[t]{2}{*}{ Farm laborers and supervisors } & 26.1 & 17.9 & 13.6 & 9.2 & 7.1 & 0.6 & 3.9 \\
\hline & \multicolumn{7}{|c|}{ Percentage of All Black Employees in Occupational Category } \\
\hline Occupation & 1960 & 1970 & 1980 & 1989 & 2000 & 2010 & 2019 \\
\hline All Black employees & 100.0 & 100.0 & 100.0 & 100.0 & 100.0 & 100.0 & 100.0 \\
\hline Managers and Administrators & 2.6 & 3.5 & 5.2 & 7.1 & 9.8 & 14.0 & 11.7 \\
\hline Professional and Technical & 4.8 & 9.1 & 12.7 & 11.5 & 15.2 & 18.9 & 20.2 \\
\hline Sales & 1.5 & 2.1 & 2.9 & 7.5 & 9.4 & 10.0 & 9.0 \\
\hline Clerical & 7.3 & 13.2 & 18.4 & 17.5 & 16.8 & 15.0 & 13.3 \\
\hline Craft & 6.0 & 8.2 & 9.6 & 9.1 & 7.8 & 5.5 & 5.4 \\
\hline Operatives, including Transport & 20.4 & 23.7 & 19.4 & 16.0 & 13.0 & 15.0 & 16.3 \\
\hline Nonfarm laborers & 13.7 & 10.3 & 6.9 & 6.7 & 5.5 & 1.4 & 0.5 \\
\hline Private household & 14.2 & 7.7 & 3.2 & 1.8 & 0.8 & 4.4 & 4.4 \\
\hline Service, except Private household & 17.5 & 18.3 & 19.9 & 21.0 & 20.9 & 15.8 & 18.9 \\
\hline Farmers and Farm managers & 3.2 & 1.0 & 0.3 & 0.1 & 0.1 & 0.0 & 0.0 \\
\hline Farm laborers and supervisors & 9.0 & 2.9 & 1.5 & 1.5 & 1.0 & 0.0 & 0.2 \\
\hline
\end{tabular}

Source: United States Census Bureau, Statistical Abstract of the United States, various years, at https://www.census.gov/library/publications/time-series/statistical_abstracts.html.

Notes: In 1960 and 1970, the data for "Black" employees are essentially "non-white" employees, whereas from 1980, the data are for Blacks only. The Census occupational codes were changed substantially in 2003. The numbers and percentages for 2010 and 2019 involve an effort to cross walk the 2010 and 2019 occupational categories to the pre-2003 categories. For 2010 , the data for nonfarm laborers are specifically employees in "building and grounds cleaning and maintenance operations," which was the only occupational subcategory that was not allocated to the broad occupational categories 
other than "nonfarm laborers" in the table. Percentages in cells for some years do not add to 100.0 because of rounding errors. We are grateful to Wynn Tucker for research assistance in compiling this table.

Table IV.2: Median annual earnings in 1969 of heads of families by age cohort and occupational group

\begin{tabular}{|l|r|r|r|r|r|}
\hline \multirow{2}{*}{ Occupational category } & \multicolumn{5}{|c|}{ Median annual earnings by age group } \\
\cline { 2 - 6 } & $\mathbf{2 0 - 2 4}$ & $\mathbf{2 5 - 3 4}$ & $\mathbf{3 5 - 4 4}$ & $\mathbf{4 5 - 5 4}$ & $\mathbf{5 5 - 6 4}$ \\
\hline Professional and managerial & 6,805 & 10,458 & 12,443 & 12,356 & 11,165 \\
\hline Clerical and sales & 6,709 & 8,713 & 9,374 & 8,760 & 8,188 \\
\hline Craft & 7,171 & 8,809 & 9,262 & 9,394 & 8,881 \\
\hline Operative & 6,649 & 7,876 & 7,922 & 7,646 & 7,420 \\
\hline Laborer & 6,273 & 6,728 & 6,932 & 6,756 & 6,071 \\
\hline & \multicolumn{5}{|c|}{ Indices of earnings by age group (Laborers=100) } \\
\hline Professional and managerial & 108 & 155 & 180 & 183 & 184 \\
\hline Clerical and sales & 107 & 130 & 135 & 130 & 135 \\
\hline Craft & 114 & 131 & 134 & 139 & 146 \\
\hline Operative & 106 & 117 & 114 & 113 & 122 \\
\hline Laborer & 100 & 100 & 100 & 100 & 100 \\
\hline
\end{tabular}

Source: Robert L. Stein and Janice Neipert Hedges, "Blue-Collar/White-Collar Pay Trends: Earnings and Family Income," Monthly Labor Review, 94, 6, 1971: 13-24, at p.17.

Table IV.3, taken from the same Monthly Labor Review article as Table IV.2, shows changes in the median annual real income (in 1969 dollars) by broad occupational category from 1959 to 1969 for both family heads and families. For family heads, the largest percentage income gains were for the 35-44 age cohort. For families, which can include earners in addition to the family head, the percentage gains of the 35-44 age cohort were still highest but those of the 45-54 age cohort were close behind (and higher for those families defined as "laborer"). For family heads, the absolute income levels in the clerical and sales, operative, and laborer categories were lower for the 45-54 cohort than for the 35-44 cohort, whereas for families the absolute income levels were substantially higher in all the occupational categories for the 45-54 cohort than for the 35-44 cohort. These data indicate both upward socioeconomic mobility (as measured by income) and the increased importance of dual-income families in the U.S. economy over the decade.

Especially for blue-collar workers, the conditions of employment and earnings could differ markedly between men and women. In the 1960s and 1970s, females became much more present in the U.S. paid labor force. The ratio of Black women to Black men in the civilian labor force was 0.68 in 1960, 0.82 in 1970, and 0.96 in 1980 (see Table IV .4). Black females made enormous gains in access to clerical work, while the most important gains for Black men were in craft and operative occupations. Black females also had substantial numbers of jobs in semiskilled operative employment but were barely represented in craft occupations.

In a survey article on Black women in the labor force from 1960 to 2000, Cecilia Conrad finds that "Black women have made enormous economic progress in the past four decades. The median earnings of black women who were year-round full-time workers increased by 53 percent between 
1960 and 1970, by 23 percent between 1970 and 1980, but by less than 10 percent between 1980 and 1990 and between 1990 and 2000."20

Table IV.3: Median annual income in 1969 and percent change from 1959 of family heads and families by age cohort and occupational group

\begin{tabular}{|c|c|c|c|c|}
\hline \multirow[b]{2}{*}{ Age cohort and major occupational group } & \multicolumn{2}{|c|}{ Income of family head } & \multicolumn{2}{|c|}{ Income of family } \\
\hline & $\begin{array}{c}\text { Median } \\
\text { income in } \\
1969\end{array}$ & 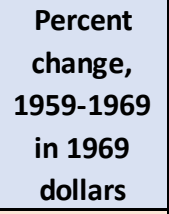 & $\begin{array}{c}\text { Median } \\
\text { income in } \\
1969 \\
\end{array}$ & $\begin{array}{c}\text { Percent } \\
\text { change, } \\
1959-1969 \\
\text { in } 1969 \\
\text { dollars } \\
\end{array}$ \\
\hline \multicolumn{5}{|l|}{ 25-34 in 1959, 35-44 in 1969} \\
\hline Professional and managerial & 12,652 & 53 & 14,658 & 61 \\
\hline Clerical and sales & 9,487 & 40 & 12,263 & 60 \\
\hline Craft & 9,363 & 31 & 11,402 & 45 \\
\hline Operative & 8,043 & 26 & 10,044 & 46 \\
\hline Laborer & 7,068 & 35 & 8,705 & 48 \\
\hline \multicolumn{5}{|l|}{ 35-44 in 1959, 45-54 in 1969} \\
\hline Professional and managerial & 12,913 & 37 & 16,408 & 56 \\
\hline Clerical and sales & 9,205 & 23 & 13,462 & 52 \\
\hline Craft & 9,607 & 23 & 12,455 & 41 \\
\hline Operative & 7,794 & 17 & 10,821 & 43 \\
\hline Laborer & 6,872 & 28 & 9,250 & 54 \\
\hline \multicolumn{5}{|l|}{ 45-54 in 1959, 55-64 in 1969} \\
\hline Professional and managerial & 11,661 & 20 & 15,751 & 34 \\
\hline Clerical and sales & 8,685 & 20 & 11,852 & 25 \\
\hline Craft & 9,107 & 26 & 11,179 & 28 \\
\hline Operative & 7,688 & 21 & 10,084 & 23 \\
\hline Laborer & 6,338 & 11 & 8,605 & 29 \\
\hline
\end{tabular}

Source: Stein and Hedges, "Blue-Collar/White-Collar Pay Trends," p.18.

${ }^{20}$ Cecilia A. Conrad, "Changes in the Labor Market Status of Black Women, 1960-2000," in Cecilia A. Conrad, John Whitehead, Patrick Mason, and James Stewart, eds. African Americans in the U.S. Economy, Rowman \& Littlefield, 2005: 157-162, at p. 157. 
Table IV.4: Black male and female shares of employment in census occupational groups, 1960,1970 , and 1980

\begin{tabular}{|l|r|r|r|r|r|r|r|}
\hline \multirow{2}{*}{\multicolumn{1}{c|}{ Occupation }} & \multicolumn{3}{c|}{ Male } & \multicolumn{4}{c|}{ Female } \\
\cline { 2 - 7 } & 1960 & 1970 & 1980 & 1960 & 1970 & 1980 \\
\hline Number of employees (000s) & 3,337 & 4,052 & 5,326 & 2,260 & 3,310 & 5,125 \\
\hline & \multicolumn{3}{|c|}{ Percentage of All Blacks in Occupational Category } \\
\hline All Black employees & 100.0 & 100.0 & 100.0 & 100.0 & 100.0 & 100.0 \\
\hline Managers and Administrators & 1.9 & 3.0 & 5.4 & 1.1 & 1.5 & 4.5 \\
\hline Professional and Technical & 3.4 & 5.8 & 7.4 & 7.7 & 11.3 & 14.4 \\
\hline Sales & 1.4 & 2.0 & 3.9 & 1.6 & 2.5 & 6.5 \\
\hline Clerical & 5.4 & 8.1 & 9.0 & 8.1 & 20.7 & 25.2 \\
\hline Craft & 10.7 & 15.3 & 15.5 & 0.7 & 1.4 & 2.4 \\
\hline Operatives, including Transport & 26.6 & 29.6 & 26.0 & 13.7 & 16.5 & 14.0 \\
\hline Nonfarm laborers & 22.3 & 15.8 & 12.3 & 1.1 & 1.5 & 3.2 \\
\hline Private household & 0.8 & 0.4 & 0.2 & 39.3 & 17.9 & 4.8 \\
\hline Service, except Private household & 15.2 & 15.6 & 16.9 & 23.0 & 25.5 & 24.5 \\
\hline Farmers and Farm managers & 4.6 & 0.9 & 0.5 & 0.7 & 0.2 & 0.1 \\
\hline Farm laborers and supervisors & 7.7 & 3.5 & 3.0 & 3.1 & 1.1 & 0.6 \\
\hline
\end{tabular}

Source: Lloyd Hogan and Harry Harris, "The Occupational-Industrial Structure of Black Employment in the United States," Review of Black Political Economy, 6, 1, 1975: 8-28, at p. 9; U.S. Census Bureau, Statistical Abstract of the United States, 1984, Government Printing Office, 1984, p.416.

As Black women accessed these employment opportunities in the 1960s and 1970s, however, there was a major increase in Black mother-only families. ${ }^{21}$ In 1968 almost 30 percent of Black children, 18 years of age and under, were living in mother-only families compared with about eight percent for whites. By 1980 the Black proportion had shot up to about 42 percent and in 1983, after the recessions of 1980-1982, to over 50 percent. It rose to as high as 54 percent in the early 1990s and then fell back to about 50 percent in $2000 .{ }^{22}$

Conrad and co-author Mary King observe that, circa 2000, "[o]ver half of African American children live in families headed by a single mother, and over 46 percent of these children are poor."

As early as 1968 , black children were roughly three times more likely to live in mother-only families than were white children. The percentage of black children living in mother-only families increased dramatically into the 1980s then leveled off. Since 1995, the percentage of black children living in families maintained by women is nearly twice the percentage of Latino children and three times the percentage of white children. ${ }^{23}$

Given the association of female-headed households with children living in poverty, we should note that the sharp increase in single-mother families among Blacks occurred in the 1960s and 1970s, when, as Conrad documents, Black women made their greatest economic gains. These findings suggest that the rise of Black female-headed households in these decades may have been, in large part, the result of the advances in equal employment opportunity for both women and Blacks prior

\footnotetext{
${ }^{21}$ Cecilia A. Conrad and Mary C. King, "Single-Mother Families in the Black Community: Economic Context and Policies," in Conrad et al., African Americans in the U.S. Economy, Rowman \& Littlefield, 2005: 163-174.

${ }^{22}$ Ibid., p. 164.

${ }^{23}$ Ibid., p. 163.
} 
to the 1980s. Conrad and King cite a study by William Julius Wilson and Kathryn Neckerman that argues that the increase among Blacks of families with a single mother was the result of the decline of the supply of marriageable Black men. ${ }^{24}$ Yet, as we have seen, Black men also experienced considerable socioeconomic progress in the 1960s and 1970s. Indeed, Conrad and King cite an article by Robert G. Wood that finds that in the 1970s changes in the supply of marriageable men accounted for only 3-4 percent of the decline in the marriage rate. ${ }^{25}$

Whether for male or female, a college education became increasingly important for upward mobility in the postwar decades. In first half of the 1970s, however, there was an oversupply of college-educated members of the U.S. labor force, ${ }^{26}$ while a high-school education was sufficient, although even then not always necessary, for entry into most of the higher-quality clerical and operative jobs that had become available to Black women and men. When these jobs provided stable employment years on end-and possibly for one's working life, Blacks found their living standards significantly improved. As documented in our previous working paper in this series, ${ }^{27}$ of particular importance to the upward socioeconomic mobility of Blacks in these decades was their entry into semiskilled blue-collar unionized employment in leading mass-production companies in automobiles, tires, electrical machinery, consumer electronics, and steel.

Table IV .5 shows improvements in Black-white annual and weekly earnings ratios in the 1960s by level of education and labor-force experience. For each work-experience cohort for elementary, high-school, and college graduates, the data show the ratios in 1970 compared to what they would have been a decade earlier. For example, in 1970, high-school graduates with 16-20 years of work experience had annual earnings that were 73.1 percent of whites in the same cohort, up from 67.6 percent in 1960, when members of this cohort had 6-10 years of work experience.

\footnotetext{
${ }^{24}$ Ibid., p. 168, citing William Julius Wilson and Kathryn Neckerman, "Poverty and Family Structure: The Widening Gap between Evidence and Public Policy Issues," in Sheldon Danziger and Daniel Weinberg, eds., Fighting Poverty: What Works and What Doesn't, Harvard University Press: 232-259.

${ }^{25}$ Conrad and King, "Single-Mother Families," p. 168, citing Robert G. Wood, "Marriage Rates and Marriageable Men: A Test of the Wilson Hypothesis," Journal of Human Resources, 5, 20, 1995: 163-193. See also David Ellwood and Jonathan Crane, "Family Change Among Black Americans: What Do We Know?" Journal of Economic Perspectives, 4, 4, 1990 : 65-84.

${ }^{26}$ Richard B. Freeman, The Overeducated American, Academic Press, 1976.

${ }^{27}$ Weitz et al. "Employment Mobility."
} 


\section{Table IV.5. Black-white earnings ratios by level of education and cohort labor-force experience, 1960 and 1970}

\begin{tabular}{|r|r|r|r|r|}
\hline & \multicolumn{2}{|c|}{$\begin{array}{c}\text { Average annual } \\
\text { earnings }\end{array}$} & \multicolumn{2}{c|}{$\begin{array}{c}\text { Average weekly } \\
\text { earnings }\end{array}$} \\
\hline $\begin{array}{c}\text { Cohort } \\
\text { experience } \\
\text { as of } 1970\end{array}$ & 1970 & 1960 & 1970 & 1960 \\
\hline \multicolumn{5}{|c|}{ Elementary School Graduates (8 years completed) } \\
\hline 1 to 5 & 0.835 & -- & 0.865 & -- \\
\hline 6 to 10 & 0.779 & -- & 0.802 & -- \\
\hline 11 to 15 & 0.708 & 0.673 & 0.737 & 0.703 \\
\hline 16 to 20 & 0.710 & 0.688 & 0.717 & 0.713 \\
\hline 21 to 30 & 0.749 & 0.671 & 0.763 & 0.708 \\
\hline 31 to 40 & 0.721 & 0.719 & 0.740 & 0.741 \\
\hline
\end{tabular}

High School Graduates (12 years completed)

\begin{tabular}{|r|r|r|r|c|}
\hline 1 to 5 & 0.775 & -- & 0.806 & -- \\
\hline 6 to 10 & 0.769 & -- & 0.791 & -- \\
\hline 11 to 15 & 0.729 & 0.654 & 0.749 & 0.714 \\
\hline 16 to 20 & 0.731 & 0.676 & 0.750 & 0.714 \\
\hline 21 to 30 & 0.678 & 0.655 & 0.698 & 0.685 \\
\hline 31 to 40 & 0.675 & 0.623 & 0.690 & 0.648 \\
\hline College Graduates $(16$ years completed) \\
\hline 1 to 5 & 0.716 & -- & 0.775 & -- \\
\hline 6 to 10 & 0.647 & -- & 0.692 & -- \\
\hline 11 to 15 & 0.662 & 0.618 & 0.688 & 0.655 \\
\hline 16 to 20 & 0.654 & 0.559 & 0.675 & 0.582 \\
\hline 21 to 30 & 0.519 & 0.446 & 0.557 & 0.470 \\
\hline 31 to 40 & 0.504 & 0.389 & 0.522 & 0.421 \\
\hline
\end{tabular}

Source: James P. Smith and Finis R. Welch,

"Black-White Male Wage Ratios:

1960-70," American Economic

Review, 67, 3, 1977: 323-338, at p.

324.

Apart from college graduates with 21-30 years of experience in 1970, the closing of the Blackwhite earnings gap was greater for annual earnings than for weekly earnings, implying that Blacks who had more steady work year-round gained more ground toward income equality with whites over the decade. Comparing the same experience cohort across the three educational levels, the annual earnings gap was lowest among the least educated and least experienced members of the labor force in 1979, except for the 11-15 years of experience cohort of high-school graduates compared with elementary school.

While the rate of Black economic advancement was much slower in the 1970s than in the 1960s, there was significant progress, helping to maintain the movement toward equal employment opportunity for Blacks, including the promise of upward intergenerational socioeconomic mobility 
for African American families. Table IV.6 shows the percentage increases in earnings by race for the various broad occupational categories from 1973 to 1980 and changes in the Black/white earnings ratio. The rate of increase of Black earnings outpaced those of whites in the sales and two operative categories (as well as farmworkers, but Blacks had become a very small proportion of farm labor force). Of greatest importance to the reversal of economic fortunes that the turn of the decade would bring, Blacks continued to close the earnings gap in the operative categories, which remained the most numerous occupations through which Blacks with no more than a high-school education could hope to enter the American middle class.

Table IV.6. Percentage earnings increases of Black and whites and Black-white earnings ratios by occupational category, 1973 and 1980

\begin{tabular}{|l|r|r|r|r|}
\hline & \multicolumn{2}{|c|}{ Percent increase in } & \multicolumn{2}{c|}{ Black/white } \\
\hline \multicolumn{1}{|c|}{ Occupation } & Black & \multicolumn{1}{c|}{ White } & \multicolumn{1}{c|}{1973} & 1980 \\
\hline Managers and administrators & 42.4 & 58.2 & 87.9 & 79.1 \\
\hline Professional and technical & 58.3 & 57.5 & 89.7 & 90.2 \\
\hline Sales & 76.9 & 64.0 & 71.3 & 77.0 \\
\hline Clerical & 47.5 & 63.6 & 107.8 & 97.2 \\
\hline Craft & 61.7 & 66.5 & 84.8 & 82.3 \\
\hline Operative, except transport & 77.4 & 70.4 & 85.2 & 88.7 \\
\hline Tranport equipment operative & 89.9 & 63.6 & 73.3 & 95.1 \\
\hline Nonfarm laborer & 58.0 & 56.6 & 83.2 & 83.9 \\
\hline Private household worker & 123.5 & 157.6 & 154.5 & 133.1 \\
\hline Other service worker & 67.0 & 64.3 & 92.0 & 93.3 \\
\hline Farmworker & 73.7 & 67.3 & 75.2 & 78.1 \\
\hline
\end{tabular}

Source: Diane Nilsen Westcott, "Blacks in the 1970's: Did They Scale the Job Ladder?" Monthly Labor Review, 105, 6, 1982: 29-38, at p. 37.

\section{Rationalization in the 1980s and beyond}

From the late 1970s, in industries that had been central to U.S. innovation, employment, and growth, U.S. corporations faced formidable Japanese competition. ${ }^{28}$ The Japanese challenge came in industries such as automobiles, consumer electronics, machine tools, steel, and microelectronics in which the United States was a world leader. The critical source of Japan's competitive advantage over the United States was "organizational integration": through the hierarchical integration of shop-floor workers and the functional integration of technical specialists into processes of organizational learning, the Japanese perfected, and outcompeted, the U.S. "Old Economy" business model that underpinned U.S. post-World War II industrial leadership. ${ }^{29}$

The Old Economy business model had provided a large measure of stable and equitable growth that benefited both blue-collar and white-collar male workers in the United States in the postWorld War II decades. Yet, even though unionized blue-collar workers had a high degree of job security in this era, they had historically been excluded from the processes of organizational learning within the corporation, reflecting a uniquely American hierarchical segmentation between

28 William Lazonick, "Innovative Business Models and Varieties of Capitalism: Financialization of the US Corporation," Business History Review, 84, 4, 2010: 675-702.

29 William Lazonick, "Organizational Learning and International Competition," in Jonathan Michie and John Grieve Smith, eds., Globalization, Growth, and Governance, Oxford University Press, 1998: 204-238 
"management" and "labor." ${ }^{30}$ Faced by Japanese competition, this exclusion of shop-floor workers from the processes of organizational learning proved to be the Achilles heel of U.S. manufacturing.

An institutional pillar of Japan's economic development in the last half of the twentieth century was permanent salaried employment for male workers at both the blue-collar and white-collar levels. ${ }^{31}$ The prime source of Japanese competitive advantage was the extension of organizational learning - which is the essence of innovative enterprise - from the managerial structure populated by college-educated professional, technical, and administrative employees to shop-floor production workers, with no more than high-school educations, so that both groups working together could contribute to productivity improvements. Complementing this hierarchical integration of the learning of white-collar and blue-collar workers was the collaboration of Japanese technical specialists in solving productivity problems in manufacturing. The functional integration of their skills and efforts contrasted with the relatively high degree of functional segmentation of technical specialists in the United States. ${ }^{32}$ In sum, it was a more hierarchically and functionally integrated system of organizational learning that from the 1970s enabled Japanese manufacturers to outcompete U.S. manufacturers in a range of industries in which U.S. companies had previously been world leaders.

The particular impacts of Japanese competition varied markedly across U.S. industries. It virtually wiped out the U.S.-based consumer-electronics industry. For example, in 1981 RCA, with 119,000 employees, was one of the leading consumer-electronics companies in the world and the $44^{\text {th }}$ largest U.S. industrial company by revenues. ${ }^{33}$ By 1986 General Electric had taken over RCA and had sold it off in pieces. During the 1980s, U.S. automobile manufacturers attempted to learn from the Japanese, but three decades later the U.S. companies were still producing lower-quality, highercost cars and, not surprisingly, had lost significant market share. ${ }^{34}$ In the machine-tool industry, the overwhelming success of the Japanese against the major U.S. companies was followed in the 1990s by the emergence of export-oriented, small- and medium-sized enterprises producing for specialized niche markets. ${ }^{35}$ In the steel industry, the innovative response of the United States was the emergence of minimills, using electric arc furnaces and scrap metal, as distinct from the traditional vertically integrated mills that converted iron ore into crude steel before making finished products. In the 1980s, the minimills only had the technological capability to manufacture long products such as bars and rails, but, led by Nucor, the introduction of compact stripproduction technology in 1989 enabled the minimills to compete with integrated mills in flat products such as plates and sheets as well..$^{36}$

30 See William Lazonick, Competitive Advantage on the Shop Floor, Harvard University Press, 1990.

31 William Lazonick, "The Institutional Triad and Japanese Development" [translated into Japanese] in Glenn Hook and Akira Kudo, eds., The Contemporary Japanese Enterprise, Yukikaku Publishing, 2005, Volume 1: 55-82.

32 Kim B. Clark and Takahiro Fujimoto, Product Development Performance: Strategy, Organization, and Management in the World Auto Industry, Harvard Business School Press, 1991; Lazonick, "Organizational Learning"; Lazonick, "Innovative Business Models."

33 Alfred D. Chandler, Jr., Inventing the Electronic Century: The Epic Story of the Consumer Electronics and Computer Industries, Free Press, 2001, pp. 13-49.

34 Michaela D. Platzer and Glennon J. Harrison, "The U.S. Automotive Industry: National and State Trends in Manufacturing Employment," Congressional Research Service, R40746, 2009, at http://digitalcommons.ilr.cornell.edu/key_workplace/666.

35 Ronald V. Kalafsky and Alan D. MacPherson, "The Competitive Characteristics of U.S. Manufacturers in the Machine Tool Industry," Small Business Economics, 19, 4, 2002: 354-369.

36 Frank Giarratani, Gene Gruver, and Randall Jackson, "Clusters, Agglomeration, and Economic Development Potential: Empirical Evidence Based on the Advent of Slab Casting by U.S. Steel Minimills," Economic Development Quarterly, 21, 2, 2007: $148-164$. 
The most perilous, but ultimately successful, U.S. response to Japanese competition was in the semiconductor industry. By the middle of the 1980s, the Japanese had used their integrated skill bases to lower defects and raise yields in the production of memory integrated circuits, transforming one of the most revolutionary technologies in history into mass-produced goods known as "commodity chips." This development forced major U.S. semiconductor companies to retreat from the memory segment of the market, with Intel, a key U.S. chip company, facing the possibility of bankruptcy in the process. ${ }^{37}$

Since 1981, however, Intel had been producing microprocessors for the IBM PC and its clones, and on this basis emerged by the beginning of the 1990s as the world's leading chip manufacturer. More generally, during the 1980s, as the Japanese (and then the South Koreans) were taking over the memory-chip market, U.S. companies became world leaders in the production of logic integrated circuits, where value was added through chip design rather than manufacturing yield, the area in which the Japanese now excelled. Indeed, relying on the Intel microprocessor and the Microsoft operating system, the rapid emergence of the IBM PC as the industry "open systems"or "Wintel" - standard in the years after its launch in 1981 was the technological basis for the rise of a "New Economy business model," characterized by employment relations that were, as we detail below, rationalized, marketized, and globalized. ${ }^{38}$

The adverse impact on U.S. employment of Japanese competition in consumer electronics, automobiles, steel, and machine tools became particularly harsh in the double-dip recession of 1980-1982 when large numbers of blue-collar jobs permanently disappeared from U.S. industry. ${ }^{39}$ Previously, in a more stable competitive environment, U.S. manufacturing companies would lay off workers with the least seniority in a downturn and re-employ them when economic conditions improved. In the beginning of the 1980s, however, it became commonplace for companies to shutter whole plants. ${ }^{40}$ From 1980 to 1985 , employment in the U.S. economy increased from 104.5 million to 107.2 million workers, or by 2.6 percent. But employment of operators, fabricators, and laborers fell from 20.0 million to 16.8 million, a decline of 15.9 percent, notwithstanding an expanding economy from 1983 to $1985 .{ }^{41}$

As Daniel Hamermesh observes, "each year during the eighties, plant closings in the U.S. displaced roughly one-half million workers with three-plus years on the job." 42 Over the course of the 1980s, the stock market came to react favorably to permanent downsizings of the blue-collar labor force. ${ }^{43}$ As secure middle-class jobs for high-school-educated blue-collar workers

37 Robert A. Burgelman, "Fading Memories: A Process Theory of Strategic Business Exit in Dynamic Environments," Administrative Science Quarterly, 39, 1, 1994: 24-56; Daniel I. Okimoto and Yoshio Nishi, "R\&D Organization in Japanese and American Semiconductor Firms," in Masahiko Aoki and Ronald Dore, eds., The Japanese Firm: The Sources of Competitive Strength, Oxford University Press, 1994: 178-208.

${ }^{38}$ Lazonick, Sustainable Prosperity.

${ }^{39}$ Robert W. Bednarzik, "Layoffs and Permanent Job Losses: Workers' Traits and Cyclical Patterns," Monthly Labor Review, September,1983: 3-12.

${ }^{40}$ Daniel S. Hamermesh, "What Do We Know About Worker Displacement in the U.S.?” Industrial Relations, 28, 1, 1989: 5159; Candee S. Harris, "The Magnitude of Job Loss from Plant Closings and the Generation of Replacement Jobs: Some Recent Evidence," Annals of the American Academy of Political and Social Science, 475, 1984: 15-27.

${ }^{41}$ U.S. Department of Commerce, Bureau of the Census, Statistical Abstract of the United States 1984, 104 ${ }^{\text {th }}$ edition, U.S. Government Printing Office, 1983, p. 416; U.S. Department of Commerce, Bureau of the Census, Statistical Abstract of the United States 1987, 107 ${ }^{\text {th }}$ edition, U.S. Government Printing Office, 1986, p. 386.

${ }^{42}$ Hamermesh, "What Do We Know," p. 53.

${ }^{43}$ John M. Abowd, George T. Milkovich, and John M. Hannon, "The Effects of Human Resource Management Decisions on Shareholder Value," Industrial and Labor Relations Review, 43, Special Issue: 1990: 203S-233S; Oded Palmon, Huey-Lian 
permanently disappeared, there was no commitment on the part of those who managed U.S. industrial corporations, or the Republican administrations that ruled in the 1980s, to invest in the new capabilities and opportunities required to upgrade the quality, and expand the quantity, of well-paid employment opportunities in the United States on a scale sufficient to reestablish conditions of prosperity for these displaced members of the labor force.

Among blue-collar workers, Blacks were extremely hard hit by the rationalization of employment in the 1980s. They were overrepresented in the mass-production sectors of the Old Economy, such as steel, autos, and consumer electronics, and underrepresented in the rising sectors of the New Economy related to the microelectronics revolution. Besides losing jobs when plants were closed, many Blacks had recently moved into unionized jobs, so that when some workers in an establishment were laid off, Blacks were more likely to have been the last hired and hence were the first fired. ${ }^{44}$ The disappearance of these middle-class jobs had devastating impacts on the abilities and incentives of Blacks to accumulate the education and experience required to position themselves for the types of well-paid and stable employment opportunities that remained. ${ }^{45}$

The recoveries that followed the recessions of 1990-1991, 2001, and 2007-2009 were "jobless": macroeconomic growth was not accompanied by job growth. Technically, the recovery from the recessionary conditions of 1980-1982 was not "jobless" because employment opportunities created by the microelectronics boom in the first half of the 1980s offset the joblessness that remained in the traditional manufacturing sector as the U.S. economy began to grow. The halfdecade 1980-1985 saw increases in employment of mathematical and computer engineers from 330,000 to 571,000 and computer programmers from 318,000 to $534,000 .{ }^{46}$ But Blacks made up only about six percent of these occupations and were more highly represented in lower-paid technical jobs. In contrast, Blacks held 14.7 percent of the "operator, fabricator, and laborer" jobs, an occupational category in which employment declined by 3.2 million from 1980 to 1985. Within that broad occupational category, the number of "machine operator, inspector, and assembler" jobs - which tended to be better paid - declined from 10.1 million in 1980 to 7.8 million in 1985 . And at the end of this period, Blacks held 14.3 percent of these jobs. Blacks, that is, had what were at the time still well-paid union jobs, but in blue-collar occupational categories that, for the first time since the end of World War II, were in widespread decline.

The extent to which Blacks held unionized manufacturing jobs in the transition from the 1970s to the 1980s has been documented by John Schmitt and Ben Zipperer, using Current Population Survey data, with statistics for Black participation in manufacturing jobs as well as for a subset of automobile industry jobs from 1979 through 2007 and for Black representation by unions from 1983 through 2007. In Table IV.7, we have used the 1983 data from Schmitt and Zipperer to provide a snapshot of the relative position of Blacks in the U.S. civilian labor force just after the

Sun, and Alex P. Tang, "Layoff Announcements: Stock Market Impact and Financial Performance," Financial Management, 26, 3, 1997: 54-68; Javad Kashefi and Gilbert J. McKee, "Stock Prices' Reactions to Layoff Announcements," Journal of Business and Management, 8, 2, 2002: 99-107.

${ }^{44}$ Lori Kletzer, “Job Displacement,” Journal of Economic Perspectives, 12, 1, 1998: 115-136; Ronald Fairlie and Lori Kletzer, "Jobs Lost, Jobs Regained: An Analysis of Black/White Differences in Job Displacement in the 1980s," Industrial Relations,

37, 4, 1998: 460-477; Rochelle Sharpe, "Unequal opportunity: Losing ground on the employment front," Wall Street Journal, September 14, 1993: A12-A13.

${ }^{45}$ William Julius Wilson, "When Work Disappears," Political Science Quarterly, 111, 4, 1996-97: 567-595.

${ }^{46}$ U.S. Department of Commerce, Statistical Abstract 1984, p. 416; Statistical Abstract 1987, p. 386. 
recession years of 1980-1982 (and the earliest year that we can bring together the data on manufacturing employment and union employment).

What is striking, as shown in Table IV.7, is how well Blacks were represented in both automobile manufacturing and unions in the early 1980s. Blacks, both female and male, were 9.2 percent of the total labor force but 14.2 percent of auto workers and 13.7 percent of unions members. In all manufacturing, however, the representation by Blacks was about the same as the representation by whites. Schmitt and Zipperer do not provide data on the proportions of the manufacturing and auto labor forces that were male and female by race and ethnicity. Table IV.7 shows that, compared with Black males, Black females represented higher proportions of the total labor force (10.4 percent versus 8.3 percent) and union labor force (16.8 percent versus 12.0 percent). While a much higher proportion of Black male workers than Black female workers were in unions (36.0 percent versus 27.4 percent), both Black groups were more highly dependent on unionized jobs than whites, Hispanics, and other groups.

Table IV.8 compares Black and white representation in the total, manufacturing, auto, and union labor forces from 1979 through 2007, using a four-year average for 1979-1982 (for which data on unions are unavailable) and five-year averages thereafter. Black representation in the total labor force increased over time, while its shares of the manufacturing, auto, and union labor forces exhibited stability over the three decades (with some increase in the union proportion during the 1990s). The Black-female share of the total labor force increased from 10.6 percent in 1979-1982 to 12.3 percent in 2003-2007, while the Black-male share increased from 8.3 percent to 9.3 percent. In contrast, white representation in all the categories declined throughout the entire period, giving way to increased representations by Hispanics and "Others," mainly Asians. Hispanics were 5.1 percent of the total labor force in 1979-1982 and 13.2 percent in 2003-2007, while the proportions for Others increased from 2.3 percent to 5.8 percent. From 1993 to 2007, Blacks were somewhat underrepresented in manufacturing but overrepresented in automobiles at 14.0 percent and unions at 13.8 percent of the total. 
Table IV.7: Composition of the U.S. labor force, by race, ethnicity, gender, and union membership, 1983

\begin{tabular}{|c|c|c|c|c|}
\hline Females and Males & Blacks & Whites & Hispanic & Other \\
\hline \multicolumn{5}{|l|}{ Percent of labor force } \\
\hline Total & 9.2 & 83.0 & 5.2 & 2.6 \\
\hline All manufacturing & 9.2 & 82.2 & 6.0 & 2.6 \\
\hline Auto manufacturing & 14.2 & 81.1 & 3.4 & 1.3 \\
\hline Union members & 13.7 & 78.1 & 5.8 & 2.4 \\
\hline \multicolumn{5}{|c|}{ Percent of ethnic/racial group } \\
\hline All manufacturing & 20.6 & 20.5 & 23.8 & 20.7 \\
\hline Auto manufacturing & 1.5 & 1.0 & 0.6 & 1.0 \\
\hline Union members & 31.7 & 22.2 & 24.2 & 23.3 \\
\hline Females & Blacks & Whites & Hispanic & Other \\
\hline \multicolumn{5}{|l|}{ Percent of labor force } \\
\hline Total & 10.4 & 82.2 & 4.8 & 2.6 \\
\hline Union members & 16.8 & 74.7 & 5.6 & 2.9 \\
\hline \multicolumn{5}{|c|}{ Percent of ethnic/racial group } \\
\hline Union members & 27.4 & 16.5 & 20.1 & 18.0 \\
\hline Males & Blacks & Whites & Hispanic & Other \\
\hline \multicolumn{5}{|l|}{ Percent of labor force } \\
\hline Total & 8.3 & 83.7 & 5.6 & 2.4 \\
\hline Union members & 12.0 & 80.0 & 5.9 & 2.1 \\
\hline \multicolumn{5}{|c|}{ Percent of ethnic/racial group } \\
\hline Union members & 36.0 & 27.0 & 27.0 & 27.7 \\
\hline
\end{tabular}

Source: John Schmitt and Ben Zipperer, "The Decline of African-American Representation in Unions and Manufacturing, 1979-2007," Center for Economic Policy and Research Issue Brief, February 2008.

While Blacks maintained relatively high shares of automobile and unionized employment from the late 1970s to 2007, both categories of jobs were disappearing, as is evident in Table IV.9. At the beginning of the period almost 23 percent of Blacks were in manufacturing jobs, whereas in 2003-2007, it was just over 10 percent. In the single year 2007, with the Great Recession in its initial stage, manufacturing jobs as a proportion of all jobs held by Blacks were 9.8 percent, and the comparable figure for whites was 11.1 percent.

The progressive movement of Blacks into unionized blue-collar jobs in mass-production industries in the 1960s and 1970s gave them greatly increased access to what were then middle-class employment opportunities. From the 1980s, however, the decline in the number of these massproduction jobs significantly reduced the quantity of these employment opportunities for highschool-educated workers while declines in real wages and benefits that one could earn in an increasing proportion of these jobs often meant that they ceased to be "middle class." To delve into when, how, and to what extent this unmaking of the Black blue-collar middle class occurred in the United State, we take a closer look at the employment experience of Black workers in the U.S. automobile industry over the past half century. 
Table IV.8: Percentages of Blacks and whites in the U.S. labor force, by total, manufacturing, automobiles, and union membership, 1979-2007

\begin{tabular}{|c|c|c|c|c|c|c|c|c|}
\hline & \multicolumn{2}{|c|}{$\begin{array}{c}\text { Total labor force } \\
\%\end{array}$} & \multicolumn{2}{|c|}{$\begin{array}{c}\text { Manufacturing labor } \\
\text { force } \%\end{array}$} & \multicolumn{2}{|c|}{$\begin{array}{c}\text { Automobile labor force, } \\
\%\end{array}$} & \multicolumn{2}{|c|}{$\begin{array}{c}\text { Union labor force } \\
\%\end{array}$} \\
\hline & Black & White & Black & White & Black & White & Black & White \\
\hline $1979-1982$ & 9.3 & 83.4 & 9.2 & 82.4 & 13.6 & 82.7 & NA & $\mathrm{NA}$ \\
\hline 1983-1987 & 9.6 & 81.6 & 9.6 & 80.4 & 14.2 & 80.1 & 14.0 & 76.8 \\
\hline 1988-1992 & 10.0 & 79.4 & 9.9 & 78.4 & 13.6 & 80.3 & 14.6 & 75.1 \\
\hline 1993-1997 & 10.4 & 77.2 & 9.9 & 76.3 & 14.0 & 78.3 & 14.7 & 73.6 \\
\hline 1998-2002 & 10.9 & 73.9 & 9.9 & 73.4 & 14.2 & 76.3 & 14.8 & 71.8 \\
\hline 2003-2007 & 10.7 & 70.2 & 9.3 & 70.1 & 14.0 & 73.6 & 13.8 & 69.4 \\
\hline
\end{tabular}

Source: Schmitt and Zipperer, “The Decline of African-American Representation"

Table IV.9: Proportions of the Blacks and white labor forces in manufacturing, automobiles, and unions, 1979-2007

\begin{tabular}{|l|c|c|c|c|c|c|c|c|}
\hline & \multicolumn{3}{|c|}{ Percentage of all Black members of the labor force } & \multicolumn{3}{|c|}{ Percentage of all white members of the labor force } \\
\cline { 2 - 10 } & $\begin{array}{c}\text { Manufac- } \\
\text { turing labor } \\
\text { force, \% }\end{array}$ & $\begin{array}{c}\text { Auto } \\
\text { workers, \% }\end{array}$ & $\begin{array}{c}\text { Union } \\
\text { members, } \\
\text { female, \% }\end{array}$ & $\begin{array}{c}\text { Union } \\
\text { members, } \\
\text { male, \% }\end{array}$ & $\begin{array}{c}\text { Manufac- } \\
\text { turing labor } \\
\text { force, \% }\end{array}$ & $\begin{array}{c}\text { Union } \\
\text { workers, \% }\end{array}$ & $\begin{array}{c}\text { Union } \\
\text { members, } \\
\text { members, } \\
\text { female, \% }\end{array}$ & $\begin{array}{c}\text { male, \% } \\
\text { mato }\end{array}$ \\
\hline $\mathbf{1 9 7 9 - 1 9 8 2}$ & 22.6 & 1.5 & NA & NA & 22.5 & 1.0 & NA & NA \\
\hline $\mathbf{1 9 8 3 - 1 9 8 7}$ & 20.2 & 1.6 & 24.4 & 31.6 & 20.0 & 1.1 & 14.8 & 24.2 \\
\hline $\mathbf{1 9 8 8 - 1 9 9 2}$ & 18.3 & 1.4 & 21.9 & 27.6 & 18.3 & 1.0 & 13.7 & 21.1 \\
\hline $\mathbf{1 9 9 3 - 1 9 9 7}$ & 16.1 & 1.3 & 20.0 & 24.2 & 16.6 & 1.0 & 13.4 & 18.8 \\
\hline $\mathbf{1 9 9 8 - 2 0 0 2}$ & 13.5 & 1.2 & 17.2 & 21.3 & 14.8 & 1.0 & 12.5 & 16.9 \\
\hline $\mathbf{2 0 0 3 - 2 0 0 7}$ & 10.4 & 1.3 & 15.4 & 18.0 & 13.8 & 1.0 & 12.2 & 15.1 \\
\hline
\end{tabular}

Source: Schmitt and Zipperer, "The Decline of African-American Representation"

\section{Black employment in the U.S. automobile industry since the 1970s}

The early 1980s was a turbulent period for employment in the U.S. automobile industry, as shown in Figure IV.1. The survey of auto employment in the 1980s in Monthly Labor Review called it "a decade of transition." ${ }^{47}$ Employment in the automobile industry plummeted in the double-dip recession of 1980-1982, and, with the permanent plant closings that marked the new era of rationalization, it only partially recovered in the subsequent eight years of growth.

Indeed, in 1979 the decline in auto employment was already underway, with 1978 marking an alltime peak in the motor vehicles and equipment census classification. ${ }^{48}$ In December 1979, a $\mathrm{New}$ York Times article entitled "A growing despair in Detroit" reported 116,000 auto workers on indefinite layoff throughout the United States. ${ }^{49}$ By June 1980, in the previous year U.S. automakers had permanently shuttered nine major plants, employing 15,000 workers, while the

\footnotetext{
${ }^{47}$ Christopher J. Singleton, “Auto Industry Jobs in the 1980's: A Decade of Transition,” Monthly Labor Review, February 1992 : 18-27.

${ }^{48}$ U.S. Bureau of the Census, Statistical Abstract of the United States, 1980, $101^{\text {st }}$ edition, U.S. Government Printing Office, 1980, p. 413.

49 William Serrin, “A growing despair in Detroit: Jobless rates rise as car sales fall," New York Times, December 13, 1979, at http://www.nytimes.com/1979/12/13/archives/a-growing-despair-in-detroit-jobless-rates-rise-as-car-sales-fall.html.
} 
number of those on indefinite layoff had risen to 239,050 , with another 60,800 temporarily unemployed..$^{50}$

Figure IV.1: Employment in motor vehicles and equipment, seasonally adjusted, 1979-1990

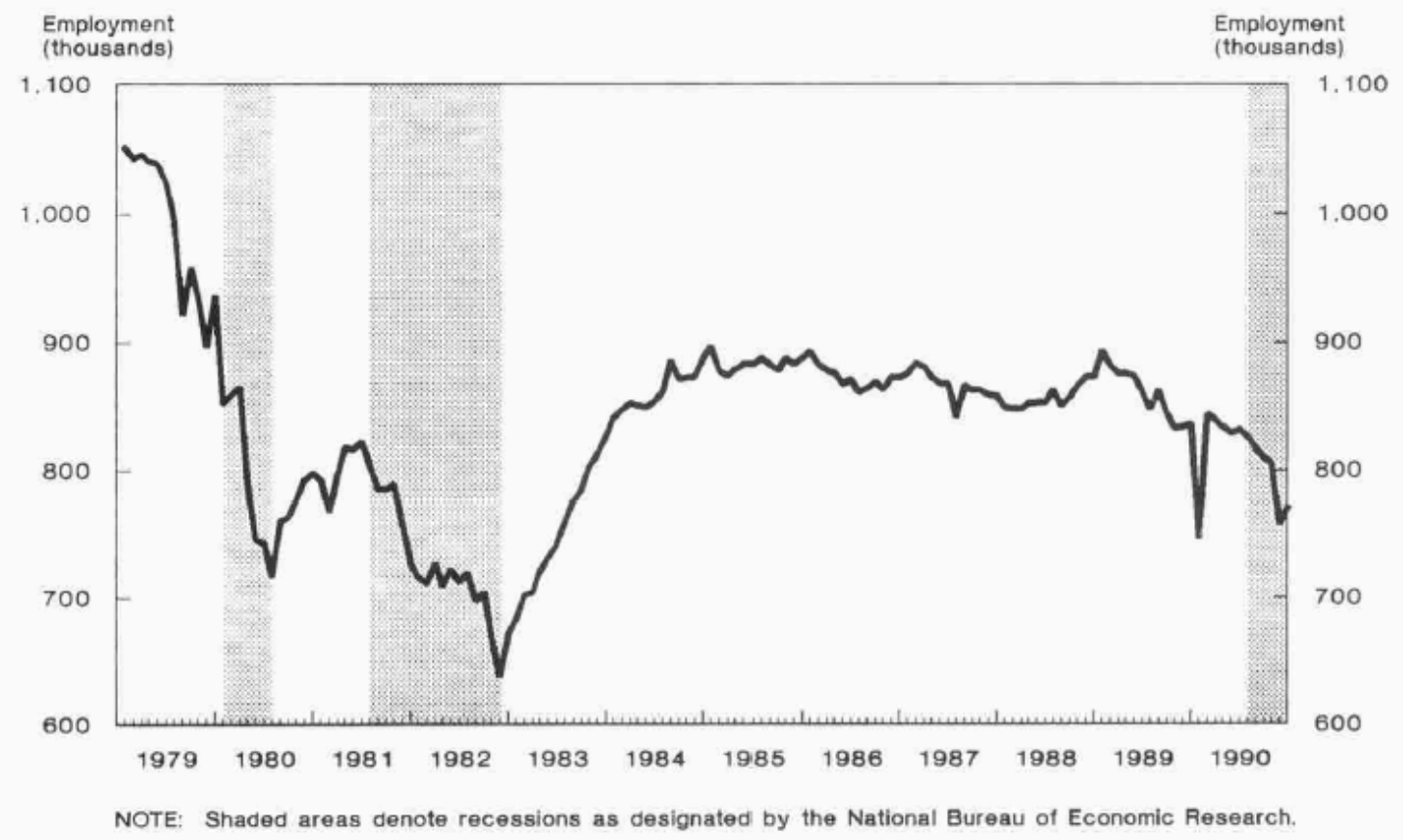

Source: Figure reproduced from Singleton, “Auto industry jobs in the 1980’s,” p. 20.

In the midst of the second oil crisis brought on by the Iranian revolution and the Iran-Iraq war, the problem for U.S. auto manufacturers was the acceleration of Japanese competition with their highquality, fuel-efficient cars and their highly productive model of organizational integration. Over the course of the 1980s, the Japanese competed not only with imports but also by building production facilities in the United States. As shown in Table IV.10, also taken from the Monthly Labor Review "decade in transition" article, during the 1980s sales by the major U.S. automakers were replaced by increased imports and Japanese "transplants" operating in the United States.

Coming into the 1980s, the only foreign car manufacturer in the United States was Volkswagen, which had taken over a partially built Chrysler plant in 1978 to assemble the Rabbit. Volkswagen would pull out of the United States in 1987, eventually to return almost a quarter century later with the opening of a factory in Chattanooga, Tennessee in 2011. In the 1980s, however, a number of Japanese automakers launched manufacturing plants in the United States. The strengthening of the yen against the dollar and rising wages in Japan shifted the economic calculation toward a transplant production model. Voluntary export restraints, adopted as a U.S. policy in trade negotiations to limit Japanese imports in 1981, became effective after 1985, reinforcing the transplant movement. ${ }^{51}$ Japanese imports reached a peak of 2.4 million units in 1986, and by 1990

\footnotetext{
${ }^{50}$ Robert Hanley, "Last Ford leaves Mahwah plant; 4,500 employees lose their jobs," New York Times, June 21, 1980, at https://timesmachine.nytimes.com/timesmachine/1980/06/21/111248141.html?pageNumber=1. As this article detailed: "Those laid off included 155,000 at 29 General Motors plants, 90,100 at 20 Ford plants, 54,500 at 11 Chrysler plants and 10,200 at three American motors plants."

${ }^{51}$ For one of the first media articles on voluntary export restraints (VERs) on automobiles made in Japan, see Clyde Farnsworth, "Car imports: Hints for Japan," New York Times, March 24, 1981. For the experience with VERs, see Daniel K. Benjamin,
} 
the combination of Japanese imports and transplant sales in the United States was almost 3.1 million units, representing one-third of the U.S. car market.

Table IV.10: U.S. car sales by U.S. automakers, imports, and Japanese transplants, 1979-1990

\begin{tabular}{|c|c|c|c|c|c|c|c|c|}
\hline & \multicolumn{2}{|c|}{ U.S. auto companies } & \multicolumn{2}{c|}{ Japanese transplants } & \multicolumn{2}{c|}{ Japanese imports } & \multicolumn{2}{c|}{ Total imports } \\
\cline { 2 - 10 } & $\begin{array}{c}\text { Unit sales } \\
\text { (000s) }\end{array}$ & \% of total & $\begin{array}{c}\text { Unit sales } \\
\text { (000s) }\end{array}$ & \% of total & $\begin{array}{c}\text { Unit sales } \\
\text { (000s) }\end{array}$ & \%nit sales of total & \multicolumn{1}{c|}{ (000s) } & \% of total \\
\hline $\mathbf{1 9 7 9}$ & 8,163 & 76.7 & 0 & 0.0 & 1,848 & 17.4 & 2,328 & 21.9 \\
\hline $\mathbf{1 9 8 0}$ & 6,401 & 71.3 & 0 & 0.0 & 1,977 & 22.0 & 2,397 & 26.7 \\
\hline $\mathbf{1 9 8 1}$ & 6,044 & 70.8 & 0 & 0.0 & 1,892 & 22.2 & 2,326 & 27.3 \\
\hline $\mathbf{1 9 8 2}$ & 5,665 & 71.0 & 0 & 0.0 & 1,801 & 22.5 & 2,222 & 27.9 \\
\hline $\mathbf{1 9 8 3}$ & 6,660 & 72.5 & 50 & 0.5 & 1,916 & 20.9 & 2,386 & 26.0 \\
\hline $\mathbf{1 9 8 4}$ & 7,744 & 74.5 & 164 & 1.3 & 1,906 & 18.3 & 2,442 & 23.5 \\
\hline $\mathbf{1 9 8 5}$ & 7,906 & 71.6 & 221 & 2.0 & 2,218 & 20.1 & 2,841 & 25.7 \\
\hline $\mathbf{1 9 8 6}$ & 7,675 & 67.0 & 466 & 4.1 & 2,386 & 20.8 & 3,249 & 28.3 \\
\hline $\mathbf{1 9 8 7}$ & 6,402 & 62.6 & 618 & 6.0 & 2,173 & 21.3 & 3,144 & 30.7 \\
\hline $\mathbf{1 9 8 8}$ & 6,735 & 63.6 & 766 & 7.2 & 2,103 & 19.8 & 3,067 & 28.9 \\
\hline $\mathbf{1 9 8 9}$ & 6,064 & 62.4 & 1,009 & 10.4 & 1,911 & 19.7 & 2,698 & 27.8 \\
\hline $\mathbf{1 9 9 0}$ & 5,500 & 59.2 & 1,343 & 14.4 & 1,721 & 18.5 & 2,453 & 26.4 \\
\hline
\end{tabular}

Source: Table reproduced from Singleton, "Auto industry jobs in the 1980's," p. 22, citing Automotive News (Crain Communications), various issues, as his source.

Note: U.S. automakers are General Motors, Ford, Chrysler, and American Motors.

In cases in which the Japanese entered into joint ventures with U.S. auto companies, the plants employed blue-collar workers represented by the United Auto Workers (UAW). In 1984 Toyota and General Motors formed New United Motor Manufacturing, Inc. (NUMMI) to apply Japanese management methods to produce small, fuel-efficient cars in a reopened GM plant in Fremont, California. Toyota personnel managed NUMMI's production, and the plant became increasingly focused on producing Toyota cars before it was closed in 2010. In 1987 Mazda became the only Japanese company to produce cars in the Detroit area, rooting its factory in a production facility that had belonged to Ford. In 1992, the Flat Rock assembly became a Mazda-Ford joint venture, and since 2012 it has been wholly owned by Ford. In 1988 Diamond-Star Motors, a joint venture between Mitsubishi and Chrysler, began production in Normal, Illinois. In 1991, Chrysler sold its 50-percent share to Mitsubishi, and in 2016 Mitsubishi closed the plant..$^{52}$

By 1990, the three joint ventures were producing a combined 538,000 cars ${ }^{53}$ and employed a total of 8,400 UAW members. ${ }^{54}$ Much more important to the transplant movement, however, were wholly owned facilities. Honda was the first Japanese company to build a U.S. car manufacturing plant, locating it at a greenfield site in Marysville, Ohio, with the first Accord coming off the line in 1982. Greenfield plants were established by Nissan in Smyrna, Tennessee in 1983; Toyota in Georgetown, Kentucky in 1988; and Subaru-Isuzu in Lafayette, Indiana in 1989. In 1990, these

\footnotetext{
"Voluntary Export Restraints on Automobiles, PERC, 17, 3, 1999, at https://www.perc.org/1999/09/01/voluntary-exportrestraints-on-automobiles/.

${ }^{52}$ For an account of the Japanese transplant movement, see Martin Kenney and Richard Florida, Beyond Mass Production: The Japanese System and Its Transfer to the United States, Oxford University Press, 1993.

${ }^{53}$ Singleton, "Auto Industry Jobs in the 1980's."

${ }^{54}$ Paul C. Judge, "UAW faces test at Mazda plant," New York Times, March 27, 1990; Kathy McKinney, "Diamond-Star UAW race won by challenger," The Pantagraph, June 6, 1991; Frank Swoboda, "UAW election no victory for confrontation," Washington Post, November 10, 1991.
} 
four transplants produced 960,000 vehicles ${ }^{55}$ and employed about 18,000 workers ${ }^{56}$ - none of whom were union members.

By comparison, in 1990 "the Big Three" U.S. automakers - General Motors, Ford, and Chryslerproduced 14.2 million cars in the United States and employed a total of over 437,000 hourly workers in United States, virtually all of whom were UAW members. These shares of U.S. auto employment would, however, shift dramatically over the following decades. In 2016, as a result of plant closings, automation, offshoring, and foreign competition from both transplants and imports, General Motors, Ford, and Fiat Chrysler (the Italian company having acquired the American company in 2014) employed a total of 152,000 hourly workers in the United Statesjust 35 percent of the 1990 total. Motor vehicles produced in the United States fell from an alltime peak of 16.1 million in 1986 to 12.1 million vehicles in $2016 .{ }^{57}$ Table IV.11 shows U.S. production by company in 2016. ${ }^{58}$ The U.S. "Big Three" produced 53 percent of total U.S. motor vehicle units, while the share of the Japanese companies was 33 percent. The Korean company Hyundai, with over six percent of U.S. production, was the seventh largest automaker in the United States, and three German companies had a combined seven-percent share.

Despite many attempts by the UAW from the 1980s to organize the workers in the transplants, none of them has ever had union representation..$^{59}$ UAW membership peaked in 1979 at over 1.5 million workers, but declined with the eroding fortunes of the Big Three, reaching a low of 355,000 members in 2009, with 398,829 members in 2019 (not all of whom worked in the auto industry).$^{60}$ As we have seen, Blacks entered the 1980 s well represented in both the auto industry

\footnotetext{
${ }^{55}$ Singleton, "Auto Industry Jobs in the 1980's."

${ }^{56}$ Nissan Public Relations, "Nissan to celebrate ten years in Tennessee," PRNewswire, October 24, 1990; Warren Brown, "Iacocca, rights groups attack Japanese companies' hiring," Washington Post, November 8, 1990; James R. Healey, "Profitsharing checks top \$1,700 at Honda," USA Today, November 23, 1990; Greg Andrews, "State's labor force subtly shifting to small business," Indianapolis Business Journal, September 2, 1991.

${ }^{57}$ Larry R. Moran, "Motor Vehicles. Model Year 1990," Survey of Current Business, 70, 11, 1990, p. 27; Organisation Internationale des Constructeurs d'Automobiles (OICA), "Production statistics," 1999-2016, at http://www.oica.net/production-statistics/

${ }^{58}$ Note that the OICA total for U.S. motor vehicle production in 2016 is 12.2 million units, whereas production in Table IV.5, which aggregates data in the 13 individual company reports that show some U.S. production, totals only 12.0 million units.

${ }^{59}$ See e.g., Terry Dodsworth, "UAW suffers defeat at Honda plant: Union loses tactical battle at US subsidiary of motor company," Financial Times, Match 19, 1986, p. 4; John Holusha, "U.A.W. pledges to organize employees at Japanese plants in U.S., New York Times, June 8, 1986; Gregory A. Patterson, "Nissan workers reject by 2-1 margin UAW bid to organize Tennessee plant," Wall Street Journal, July 28, 1989; Anon., "UAW moves again to organize Nissan assembly plant in Tennessee, Associated Press, June 19, 1997; Keith Bradsher, "Union moves to hold vote at Nissan plant in Tennessee," New York Times, August 15, 2001, at https://www.nytimes.com/2001/08/15/business/union-moves-to-hold-vote-at-nissan-plant-intennessee.html ; John McElroy, "Don't kiss UAW goodbye just yet,” Ward's Autoworld, August 1, 2010, p. 10; Kathy Jackson, "UAW concedes defeat at transplants - for now," Automotive News, April 27, 1998; David Shepherd and Christine Tierney, "King ups pressure on auto transplants," Detroit News, January 13, 2011; Norm Scheiber, "Nissan workers in Mississippi reject union bid by U.A.W," New York Times, August 5, 2017. The UAW has also failed to organize German plants in the United States. See e.g., Adrian Bridge and Larry Black, "BMW defies union over South Carolina plant," Independent, August 3, 1992; Anon., "Car union tries to flex muscles on Mercedes Drive," Financial Times, September 16, 1999, p. 3; William Lazonick and Tony Huzzard, "Why everyone does better when employees have a say in the workplace," OUPBlog, April 30, 2014, at https://blog.oup.com/2014/04/automobile-manufacturing-employee-voice/; Lydia DePillis, "Volkswagen workers reject UAW in Tenn.; Union looks for Plan B to enter South," Washington Post, February 15, 2014.,at https://www.washingtonpost.com/business/economy/volkswagen-workers-reject-uaw-in-tenn-union-looks-for-plan-b-to-entersouth/2014/02/15/c35c018c-967c-11e3-9616-d367fa6ea99b story.html?utm term=.9aa7470d74a4; Larry P. Vellequette, "VW workers at Tenn. plant reject second UAW organizing bid," Automotive News, June 19, 2019, at https://www .autonews.com/manufacturing/vw-workers-tenn-plant-reject-second-uaw-organizing-bid.

${ }_{60}$ UAW membership was $1,527,858$ in 1979. It was slightly higher at 1,530,870 in 1969 but declined in the 1970 s before recovering to its 1979 peak. As we have seen, U.S. employment in the motor vehicle and equipment industry peaked in 1978. Since 1979, the lowest level of UAW membership was 355,191 in 2009. It then rose to 415,963 in 2016 and 430,871 in 2017
} 
and in unions, and hence the decline of unionized employment as a blue-collar worker in the automobile industry undermined the ability of high-school-educated Blacks to attain levels of pay, employment security, and retirement benefits that could support a middle-class living standard.

Table IV.11: Motor vehicle production (units), in the USA and globally, by company, 2016

\begin{tabular}{|l|r|r|r|r|r|l|}
\hline \multicolumn{1}{|c|}{ Company } & \multicolumn{1}{c|}{ USA } & \multicolumn{1}{c|}{ Global } & $\begin{array}{c}\text { Share of } \\
\text { total US } \\
\text { production }\end{array}$ & $\begin{array}{c}\text { USA as \% of } \\
\text { global } \\
\text { production }\end{array}$ & $\begin{array}{c}\text { Head- } \\
\text { quarters }\end{array}$ & Brands (if specified) \\
\hline Ford & $2,443,474$ & $6,429,485$ & 20.3 & 38.0 & USA & \\
\hline General Motors & $2,409,929$ & $7,793,066$ & 20.0 & 30.9 & USA & \\
\hline Fiat Chrysler & $1,506,168$ & $4,681,457$ & 12.5 & 32.2 & UK* & Chrysler, Jeep, Ram \\
\hline Toyota & $1,392,047$ & $10,213,486$ & 11.6 & 13.6 & Japan & Toyota, Hino \\
\hline Honda & $1,290,052$ & $4,999,266$ & 10.7 & 25.8 & Japan & \\
\hline Nissan & $1,007,321$ & $5,556,241$ & 8.4 & 18.1 & Japan & \\
\hline Hyundai & 749,120 & $7,889,538$ & 6.2 & 9.5 & South Korea & Hyundai, Kia \\
\hline BMW & 441,987 & $2,359,756$ & 3.7 & 18.7 & Germany & \\
\hline Daimler AG & 318,165 & $2,525,450$ & 2.6 & 12.6 & Germany & Mercedes \\
\hline Fuji & 296,863 & $1,024,604$ & 2.5 & 29.0 & Japan & Subaru \\
\hline Volkswagen & 93,539 & $10,126,281$ & 0.8 & 0.9 & Germany & Volkswagen, Audi, Porsche \\
\hline Paccar & 55,547 & 139,431 & 0.5 & 39.8 & USA & \\
\hline Navistar & 17,171 & 48,447 & 0.1 & 35.4 & USA & International \\
\hline TOTAL PRODUCTION & $12,021,383$ & $63,786,508$ & 100.0 & 18.8 & & \\
\hline Big Three** & $6,359,571$ & $18,904,008$ & 52.9 & 33.6 & & \\
\hline Japanese transplants*** & $3,986,283$ & $21,793,597$ & 33.2 & 18.3 & & \\
\hline
\end{tabular}

* Fiat Chrysler Automobiles has its global headquarters in London, UK, but its Chrysler division is run from Auburn Hills, Michigan; ** Ford, General Motors, and Fiat Chrysler Automobiles; *** Toyota, Honda, Nissan, and Fuji.

NOTE: Omitted from Table IV.5 is car production of Tesla, which produced 83,922 vehicles in the United States and the Netherlands in 2016, but which apparently did not submit this information to OICA.

Source: Organisation Internationale des Constructeurs d'Automobiles (OICA), "Production statistics, 2016" at http://www.oica.net/category/production-statistics/2016-statistics/

Moreover, the proportion of the labor force that was Black tended to be much higher at the U.S. companies than at the Japanese companies, and Blacks were particularly poorly represented at Toyota, Honda, Nissan, and Fuji (Subaru), all of which had built plants in rural greenfield locations. While both U.S. and Japanese companies developed greenfield plants, because of agreements with the UAW, U.S. companies, such as GM, maintained the right of workers to retain their jobs should such positions remain available following plant relocation. Management-union agreements also gave priority to recently laid-off employees when staffing new plants.

(just below the 2008 membership level of 431,037 ) but fell back to 395,703 in 2018. United Auto Workers, "UAW grows by almost 15,000 new members in 2017; 75,000 new members since 1979," UAW news release, March 29, 2018, at https://uaw.org/uaw-grows-almost-15000-new-members-2017-75000-new-members-since-2009/; Keith Laing and Ian Thibodeau, "UAW membership dropped by 35,000 in 2018," Detroit News, March 29, 2019, at https://www.detroitnews.com/story/business/autos/2019/03/29/uaw-membership-dropped-last-year/3314861002/; Phoebe Wall Howard, "Many of UAW's newest members aren't traditional autoworkers," Detroit Free Press, April 14, 2020, at https://www.freep.com/story/money/cars/2020/04/14/uaw-membership-2019/2923908001/. 
These agreements dampened the negative impact of plant relocation on many Black auto workers, but, as these workers retired, plants absorbed more local applicants resulting in a declining number of Black employees. With the exception of the jointly operated NUMMI (GM-Toyota) plant in Fremont, California, Japanese companies, by contrast, held no such agreements, and as a result African Americans were from the outset markedly underrepresented in the ranks of their workers. Despite holding a "local employment potential" of 10.5 percent at the Honda Marysville plant in Ohio, for example, as of 1988, Blacks comprised a mere 2.8 percent of the plant's workforce. ${ }^{61}$

The hiring practices of Japanese executives were informed by a variety of considerations. Desiring to replicate Japanese management practices without being encumbered by the pre-existing attitudes and practices of U.S. workers, Japanese firms preferred employees with minimal experience in U.S. firms. Similarly, site locations were also chosen, in part, for their absence of histories of unionization. Meanwhile, geographic dispersion was meant to incentivize long-term career employment by reducing inter-plant competition for workers in a locality. ${ }^{62}$

Additional evidence suggests that Japanese executives also relied on a combination of racial and ethnic stereotypes in selecting plant location, a tendency that was likewise embedded in the desire to recreate the success of Japanese management techniques. According to one auto-industry consultant who undertook numerous studies for Japanese firms seeking to locate in the United States, executives asked for "ethnic," "religious," and "professional" demographic profiles of prospective site locations: "There are demographic aspects that they like. They like a high German content. Germans have a good work ethic - well-trained, easy to train, they accept things..." ${ }^{63}$ In a Japanese External Trade Organization publication, for example, California is noted as a good location due to the high representation of Asians in the local population. And according to one Midwestern state official involved in site location negotiations with Japanese firms in the early1980s, “...many Japanese companies at the time specifically asked to stay away from areas with high minority [i.e., Black and Hispanic] populations." 64

Until the beginning of the 2000s, the UAW hoped that it would be able to justify its traditional increases in pay and benefits through Big Three productivity gains as they closed the gap on the Japanese. When the UAW had been able to bargain for higher pay and benefits, which was the case up to the 2003 bargaining round, the Japanese transplants had to more or less match these gains if only to keep their workforces from being attracted to the UAW's organizing efforts. ${ }^{65}$ From 2003, however, it was clear that the only way in which the Big Three could compete with the Japanese was through cost cutting. That meant a reduction in the bargaining power of the UAW in securing higher wages and benefits for those of its members who remained employed by the

\footnotetext{
${ }^{61}$ Robert E. Cole and Donald R. Deskins, Jr. "Racial Factors in Site Location and Employment Patterns of Japanese Auto Firms in America," California Management Review, 31, 1, 1988: 9-22, especially pp. 14-15.

${ }^{62}$ Andrew Mair, Richard Florida, and Martin Kenney, "The New Geography of Automobile Production: Japanese Transplants in North America," Economic Geography, 64, 4, 1988: 352-373, at pp. 365-368; for greenfield site locations see also James M. Rubenstein, "Changing Distribution of the American Automobile Industry," Geographical Review, 76, 3, 1986: 288-300; James M. Rubenstein, "Further Changes in the American Automobile Industry," Geographical Review, 77, 3, 1987: 359-362.

${ }^{63}$ Cole and Deskins, "Racial Factors in Site Location, p. 17.

${ }^{64}$ Ibid., p. 18. For a statistical analysis of probable site locations for Japanese auto plants based on local characteristics, e.g., education levels and racial demographics, see Douglas P. Woodward, "Locational Determinants of Japanese Manufacturing Start-Ups in the United States," Southern Economic Journal, 58, 3, 1992: 690-708

${ }^{65}$ See David Welch and David Phillips, “Automakers, UAW open contract talks," Salt Lake Tribune, June 15, 1999; Frits K. Pil and John Paul MacDuffie, "What Makes Transplants Thrive: Managing the Transfer of 'Best Practice' at Japanese Auto Plants in North America," Journal of World Business, 34, 4, 1999: 372-391.
} 
Big Three. With UAW bargaining power weakened, it was the transplants that were able to hold the line or even reduce wages and benefits, compelling the UAW to follow suit. ${ }^{66}$

How did Blacks fare with the decline of both employment at the Big Three and the bargaining power of the UAW? The main source of data on Black employment in the automobile industry is contained in annual EEO-1 reports ${ }^{67}$ that each company with 100 or more employees submits to the EEOC on the numbers of people that it employs in the United States by gender, race, and ethnicity for ten different hierarchically-ordered occupational categories: 1) EXECUTIVES/SR OFFICIALS \& MGRS, 2) FIRST/MID OFFICIALS \& MGRS, 3) PROFESSIONALS, 4) TECHNICIANS, 5) SALES WORKERS, 6) OFFICE AND CLERICAL WORKERS, 7) CRAFT WORKERS, 8) OPERATIVES, 9) LABORERS \& HELPERS, 10) SERVICE WORKERS. ${ }^{6}$ Through 2006, the first two categories were combined as "Officials and Managers," while the Office and Clerical Workers category has also been called "Administrative Support." Documentation of the changing diversity of employment at particular companies requires that researchers have access to the actual annual EEO-1 company reports, which in many cases go back half a century. Thus far, however, the EEOC has not made these company reports publicly available. ${ }^{69}$

We can begin the analysis of the changes in Black employment in the U.S. automobile industry from the 1970s using industry-level EEO-1 data for "motor vehicles and equipment" (which we use interchangeably with "auto" in what follows). In most years since 1971, the EEOC has published these statistics in Job Patterns for Minorities and Women in Private Industry (EEO-1). Data from 1996 through 2015 (the most recent year available) are posted online. ${ }^{70}$ The Job Patterns publications combine the first two occupational categories listed above into "Officials and Managers." Note that EEO-1 data do not cover the total labor force because only firms with 100 or more employees are required to submit reports. Compared with Bureau of Labor Statistics employment data for durable goods manufacture, EEO-1 coverage was between 76 percent and 81 percent in the first decade of the publication of the Job Patterns reports (1971-1980) and in the 65-percent to 70 -percent range thereafter. ${ }^{71}$ After assessing this industry-level evidence on changes

\footnotetext{
${ }^{66}$ David Kiley, "Foreign companies cast long shadow on UAW negotiations," USA Today, August 3, 2003; Aaron Bragman, "U.S. Big Three make progress in manufacturing productivity; but Japanese companies still lead," IHS Global Insight, June 1, 2007; David Barkholz and Jamie LaReau, "UAW puts GM on Toyota's heels," Automotive News, October 1, 2007; Steve Eder, "UAW workers' pay on par with Japanese competitors in U.S.," The Blade, December 13, 2008; David Barkholz, "For Detroit 3 and UAW, the last gap with transplants," Automotive News, March 14, 2011.

${ }^{67}$ U.S. Equal Employment Opportunity Commission, "EEO-1: Who Must File”, at https://www.eeoc.gov/employers/eeo1survey/whomustfile.cfm.

${ }^{68}$ See the website of the EEODataNet project, based at University of Massachusetts Amherst, at https://www.umass.edu/eeodatanet/home.

${ }^{69}$ Some EEO-1 data have become available through Freedom of Information Act (FOIA) requests. See Mike Swift, "Blacks, Latinos, and women lose ground at Silicon Valley tech companies," Mercury News, February 11, 2010, at https://www.mercurynews.com/2010/02/11/blacks-latinos-and-women-lose-ground-at-silicon-valley-tech-companies/; Josh Harkinson, "Silicon Valley firms are even whiter and more male than you thought," Mother Jones, May 29, 2014, at https://www.motherjones.com/media/2014/05/google-diversity-labor-gender-race-gap-workers-silicon-valley/. In the forthcoming Working Paper No. 5 of this series, we present data from EEO-1 reports that a number of "tech" companies made public for some or all of the years from 2014 through 2018 as well as from some other reports for other years released by companies.

${ }^{70}$ U.S. Equal Employment Opportunity Commission, "Job Patterns for Minorities and Women in Private Industry," at https://www.eeoc.gov/eeoc/statistics/employment/jobpat-eeo1/. A few of these annual reports prior to 1996 are available as scanned copies from Hathi Trust, at https://catalog.hathitrust.org/Record/012201170. EEO-1 data are unavailable for certain years in the 1970s and 1980s.

${ }^{71}$ These comparisons are found in the introductory pages of the print editions of Job Patterns for Minorities and Women in Private Industry. For example, in the 1990 edition the comparison is found on p. vii.
} 
in employment in the auto industry, we shall gather together company-level data, from a number of sources, for each of the Big Three on how Blacks have fared at each of them since the 1960s.

Table IV.12 shows the increase in Black employment in the auto industry from 1971 to its all-time peak reported to the EEOC of almost 182,000 in 1978. Black employment then declined dramatically between 1978 and 1980, and undoubtedly fell even further in the recession of 1982 (for which we do not have EEO-1 data). ${ }^{72}$ With the mid-1980s recovery, the employment of Blacks increased to a new peak of almost 160,000 in 1986 (consistent with the motor vehicles segment data on employment in Figure IV.7 above), but then auto jobs entered into a long-run decline, with upswings in the boom years of the late 1990s and again since the depths of the Great Recession. At its lowest level on record in 2009, with under 60,000 jobs, total Black employment in the auto industry was just 33 percent of its peak level in 1978.

As can be seen in Table IV.12, throughout the 45-year period for the 37 years for which we have data, the vast majority of the jobs held by Blacks in the auto industry were in the blue-collar occupations (craft, operative, laborer, and service). In 1971, 95.5 percent of the 137,326 jobs that Blacks held were blue collar and, in 2015, 86.3 percent of 104,583 jobs. Over the whole period, the lowest proportion of Black employment that was blue collar occurred in 2009 at 84.4 percent of 59,508 jobs, the lowest level of Black employment in autos, brought on by the Great Recession.

Operative jobs, which were semiskilled positions that with union representation enabled large numbers of blue-collar workers to achieve middle-class standards of living in the post-World War II decades, were 82.6 percent of all blue-collar jobs in 1978, at the peak of Black employment in autos, and from 1988, when the numbers of Blacks employed in the auto industry began its definitive decline, through 2015 ranged from 75 percent to 79 percent.

\footnotetext{
${ }^{72}$ Census data for "motor vehicles and equipment" show total employment of 997,000 in 1978, 763,000 in 1980, and 705,000 in 1982 , and employment of production workers of 776,000 in 1978, 557,000 in 1980, and 516,000 in 1982. Applying the EEO1/BLS coverage proportion for 1971 of 77.8 percent for durable-goods manufacturing (EEOC, Job Patterns, 1971, p. xxxiv), BLS total black employment in autos in 1971 would have been about 176,500 jobs. Applying the coverage proportion for 1978 of 76.2 percent for durable-goods manufacturing (EEOC, Job Patterns, 1978, p. xi), the actual total number of auto jobs held by blacks in that year would have been about 238,400- an increase of about 62,000 jobs over the seven years. Applying the 1978 proportion of 76.9 percent (EEOC, Job Patterns, 1978, p. vii), the BLS extrapolation on the 147,050 EEO-1 jobs in 1980 would have been about 191,200 , for a decline of about 47,200.
} 
Table IV.12: Black employees in EEO motor vehicle and equipment occupational groups as percent of all Black motor vehicle and equipment employees, 1971-2015

\begin{tabular}{|c|c|c|c|c|c|c|c|c|c|c|}
\hline & \multirow[b]{2}{*}{$\begin{array}{l}\text { Total Black } \\
\text { Employees }\end{array}$} & \multicolumn{9}{|c|}{ Percent of all black motor vehicle \& equipment employees } \\
\hline & & $\begin{array}{c}\text { Officials } \\
\text { and } \\
\text { Managers }\end{array}$ & $\begin{array}{l}\text { Profes- } \\
\text { sionals }\end{array}$ & $\begin{array}{l}\text { Techn- } \\
\text { icians }\end{array}$ & $\begin{array}{c}\text { Sales } \\
\text { Workers }\end{array}$ & $\begin{array}{c}\text { Office and } \\
\text { Clerical } \\
\text { Workers }\end{array}$ & $\begin{array}{c}\text { Craft } \\
\text { Workers }\end{array}$ & $\begin{array}{l}\text { Opera- } \\
\text { tives }\end{array}$ & Laborers & $\begin{array}{l}\text { Service } \\
\text { Workers }\end{array}$ \\
\hline 1971 & 137,326 & 1.5 & 0.3 & 0.3 & 0.0 & 2.5 & 3.7 & 79.5 & 8.0 & 4.3 \\
\hline \multicolumn{11}{|l|}{1972} \\
\hline 1973 & 150,872 & 2.4 & 0.5 & 0.5 & 0.1 & 2.5 & 4.9 & 78.0 & 7.3 & 3.9 \\
\hline \multicolumn{11}{|l|}{1974} \\
\hline 1975 & 151,717 & 3.0 & 1.1 & 0.7 & 0.0 & 3.4 & 6.0 & 74.8 & 6.7 & 4.3 \\
\hline \multicolumn{11}{|l|}{1976} \\
\hline \multicolumn{11}{|l|}{1977} \\
\hline 1978 & 181,648 & 3.6 & 1.5 & 0.8 & 0.2 & 3.4 & 6.5 & 74.7 & 5.5 & 3.8 \\
\hline 1979 & 174,509 & 3.5 & 1.6 & 1.0 & 0.1 & 3.7 & 6.1 & 73.8 & 6.5 & 3.5 \\
\hline 1980 & 147,050 & 4.1 & 2.0 & 1.2 & 0.1 & 3.7 & 7.2 & 71.6 & 5.9 & 4.1 \\
\hline 1981 & 152,063 & 4.0 & 2.1 & 1.2 & 0.4 & 4.3 & 8.6 & 69.9 & 5.6 & 3.9 \\
\hline \multicolumn{11}{|l|}{1982} \\
\hline \multicolumn{11}{|l|}{1983} \\
\hline \multicolumn{11}{|l|}{1984} \\
\hline 1985 & 158,360 & 4.1 & 2.6 & 1.2 & 1.5 & 4.1 & 7.6 & 69.8 & 5.5 & 3.7 \\
\hline 1986 & 159,725 & 4.0 & 2.6 & 1.1 & 0.4 & 3.7 & 7.6 & 70.3 & 6.9 & 3.5 \\
\hline \multicolumn{11}{|l|}{1987} \\
\hline 1988 & 136,702 & 4.7 & 3.0 & 1.1 & 0.5 & 3.8 & 8.1 & 68.0 & 7.6 & 3.2 \\
\hline 1989 & 135,831 & 4.0 & 2.9 & 1.2 & 0.4 & 3.4 & 8.3 & 68.2 & 8.5 & 3.1 \\
\hline 1990 & 128,776 & 4.2 & 3.4 & 1.3 & 0.4 & 3.5 & 8.6 & 67.0 & 8.5 & 3.1 \\
\hline \multicolumn{11}{|l|}{1991} \\
\hline 1992 & 123,592 & 4.2 & 3.9 & 1.4 & 0.4 & 3.0 & 9.9 & 66.5 & 7.9 & 2.9 \\
\hline 1993 & 128,665 & 4.0 & 3.8 & 1.3 & 0.3 & 2.7 & 9.0 & 68.0 & 8.0 & 2.8 \\
\hline 1994 & 112,364 & 3.7 & 3.7 & 1.2 & 0.2 & 2.5 & 9.3 & 67.8 & 9.4 & 2.4 \\
\hline 1995 & 115,450 & 3.7 & 4.0 & 1.3 & 0.3 & 2.3 & 8.6 & 67.6 & 10.3 & 2.0 \\
\hline 1996 & 124,553 & 3.9 & 4.1 & 1.3 & 0.2 & 2.9 & 8.7 & 65.6 & 11.2 & 2.0 \\
\hline 1997 & 128,488 & 3.9 & 3.8 & 1.3 & 0.2 & 2.1 & 8.7 & 67.6 & 10.7 & 1.9 \\
\hline 1998 & 129,369 & 4.1 & 4.1 & 1.3 & 0.2 & 2.5 & 8.3 & 66.5 & 11.0 & 1.9 \\
\hline 1999 & 131,730 & 4.2 & 4.4 & 1.5 & 0.1 & 2.5 & 8.1 & 65.8 & 11.8 & 1.7 \\
\hline 2000 & 125,223 & 4.2 & 4.3 & 1.7 & 0.2 & 2.4 & 7.9 & 65.7 & 11.9 & 1.7 \\
\hline 2001 & 120,796 & 4.4 & 4.5 & 1.7 & 0.2 & 2.2 & 7.4 & 66.1 & 11.8 & 1.6 \\
\hline 2002 & 112,365 & 4.6 & 4.6 & 1.7 & 0.2 & 2.5 & 7.9 & 65.2 & 11.6 & 1.6 \\
\hline 2003 & 113,496 & 4.5 & 4.6 & 1.8 & 0.1 & 2.1 & 7.7 & 65.2 & 12.7 & 1.3 \\
\hline 2004 & 110,711 & 4.8 & 5.2 & 1.6 & 0.1 & 2.1 & 7.4 & 63.8 & 13.5 & 1.3 \\
\hline 2005 & 112,428 & 4.6 & 5.1 & 1.6 & 0.1 & 2.0 & 7.2 & 66.1 & 12.1 & 1.3 \\
\hline 2006 & 99,955 & 4.6 & 4.9 & 1.8 & 0.1 & 1.8 & 7.1 & 67.1 & 11.6 & 1.0 \\
\hline 2007 & 95,291 & 4.7 & 5.1 & 1.8 & 0.1 & 2.3 & 6.6 & 66.1 & 12.3 & 0.9 \\
\hline 2008 & 83,002 & 4.9 & 5.7 & 2.0 & 0.1 & 2.4 & 6.5 & 66.5 & 11.3 & 0.6 \\
\hline 2009 & 59,508 & 4.8 & 6.2 & 2.1 & 0.2 & 2.3 & 6.4 & 66.5 & 11.1 & 0.3 \\
\hline 2010 & 60,354 & 4.6 & 5.6 & 2.1 & 0.2 & 2.4 & 6.2 & 66.3 & 12.3 & 0.2 \\
\hline 2011 & 68,712 & 4.4 & 5.8 & 2.2 & 0.1 & 2.2 & 5.9 & 67.2 & 12.0 & 0.2 \\
\hline 2012 & 77,249 & 4.0 & 6.0 & 2.5 & 0.1 & 2.0 & 5.9 & 67.3 & 12.0 & 0.3 \\
\hline 2013 & 87,920 & 3.7 & 6.0 & 2.3 & 0.2 & 1.9 & 5.3 & 67.5 & 12.9 & 0.2 \\
\hline 2014 & 95,798 & 3.7 & 5.8 & 2.5 & 0.2 & 2.0 & 5.6 & 66.2 & 13.6 & 0.4 \\
\hline 2015 & 104,583 & 3.6 & 5.8 & 2.3 & 0.2 & 1.8 & 6.5 & 65.1 & 14.4 & 0.4 \\
\hline
\end{tabular}

Source: EEOC, Job Patterns 1971-2015

Note: Blank rows are years for which EEO-1 data are not available.

Since the 1980s, the proportion of all Black auto employees in operative positions fluctuated in a narrow band around 67 percent. The proportion of Blacks in craft positions, which would generally 
be called skilled, increased from 3.7 percent in 1971 to 6.5 percent in 1978 and then kept climbing to a high of 10.0 percent in 1992, before declining to less than six percent in 2011-2014. The peak number of craft jobs was 13,118 in 1981 and plunged as low as 3,184 in 2010 (see Table IV.13 below). Proportionally, there was a large increase in laborers jobs, classed as unskilled, reaching a high of 14.4 percent in 2015, which was also the peak year for the number of laborers jobs at just over 15,000. Service workers represented three to four percent of Black employees in the 1970s and 1980s, but became of minimal importance in recent years, probably because of outsourcing of facilities maintenance services to independent contractors who are not classified as being employed in motor vehicle and equipment occupations. ${ }^{73}$

In white-collar occupations, the proportion of Black auto employees who were officials and managers tripled from 1.5 percent in 1971 to 4.7 percent in 1988 and remained in the four to five percent range since then. The number of Blacks who were officials and managers reached a peak of 6,510 in 1978, which, as we have seen, was also the peak year for total Black employment in motor vehicle and equipment occupations. Professionals were a miniscule proportion of all Black employees in the 1970s but reached around six percent between 2007 and 2015, with peak Black employment as professionals of just over 6,000 in 2015. In more recent years, a higher proportion of Blacks found employment as technicians, but the occupational classification was never more than 2.5 percent of Black auto employees. Their peak employment was just over 2,400 in both 2014 and 2015. In contrast office and clerical workers reached a peak of 6,576 in 1981, when this category climbed to 4.3 percent of a shrunken Black labor force. As positions held by Black employees, sales work was insignificant throughout, except for an abnormally high number of just over 2,400 jobs in $1985 .^{74}$

As shown in Table IV.13, the expansion of Black employment in the 1970s was particularly advantageous to females. Of the 44,322 additional jobs recorded in 1978 compared with 1971 about one-third went to males and two-thirds went to females. For Black females, almost 60 percent of the job increase was in the operative category, which represented 75 percent of total Black employment in 1971 and 80 percent in 1980. Female operative employment went from 8,343 in 1971 to 32,040 in 1978, with women gaining 89 percent of the additional operative jobs. Another 15 percent of the job increase was as craft workers, a category in which males held 99.5 percent of the jobs in 1971 and 97.7 percent in 1978. In contrast, there was a decline in the employment of laborers of almost 1,000 jobs, although the employment of females as laborers tripled from 720 to 2,102 , while the employment of males as laborers fell by 23 percent.

As a result of the increase in female representation in autos in the 1970s, the proportion of Black females to all Black employees rose from 7.8 percent in 1971 to 25.4 percent in 1979. It kept rising over the next three decades, reaching a peak of 38.3 percent in 2008, and then ranging between 36 and 38 percent through 2015. In 2015, Black female employment in autos stood at just over 38,000, about 2,500 fewer jobs for Black females than in 1978. For Black males, the job deficit in 2015 compared with their peak employment of just over 141,000 in 1978 was 74,500. From 1981 to 2015, 67 percent to 72 percent of all Black female employees were operatives, while for Black

\footnotetext{
${ }^{73}$ On this practice more generally, see David Weil, The Fissured Workplace: Why Work Became So Bad for So Many and What Can Be Done to Improve it, Harvard University Press, 2017.

${ }^{74}$ In EEOC, Job Patterns, 1985, p. 24, the 2,408 Black sales workers represented 15 percent of all Black workers. The previous peak number was 666 in 1981 (with no data available for 1982, 1983 and 1984). In 1986, the number of Black sales workers was 560, with a peak thereafter of 642 in 1988.
} 
males, with their dominance of craft occupations, the proportion who were operatives ranged between 66 percent and 70 percent.

Table IV.13: Black employment in the motor vehicle and equipment industry, all and selected occupational groups, 1971-2015

\begin{tabular}{|c|c|c|c|c|c|c|c|c|c|c|c|c|}
\hline & \multicolumn{3}{|c|}{ All black workers } & \multicolumn{3}{|c|}{ Craft workers } & \multicolumn{3}{|c|}{ Operatives } & \multicolumn{3}{|c|}{ Laborers } \\
\hline & Total & Male & Female & Total & Male & Female & Total & Male & Female & Total & Male & Female \\
\hline 1971 & 137,326 & 126,609 & 10,717 & 5,097 & 5,074 & 23 & 109,208 & 100,865 & 8,343 & 10,947 & 10,227 & 720 \\
\hline \multicolumn{13}{|l|}{1972} \\
\hline 1973 & 150,872 & 132,855 & 18,017 & 7,341 & 7,259 & 82 & 117,721 & 103,693 & 14,028 & 10,963 & 9,603 & 1,360 \\
\hline \multicolumn{13}{|l|}{1974} \\
\hline 1975 & 151,717 & 128,925 & 22,792 & 9,138 & 9,009 & 129 & 113,518 & 96,056 & 17,462 & 10,100 & 8,758 & 1,342 \\
\hline \multicolumn{13}{|l|}{1976} \\
\hline \multicolumn{13}{|l|}{1977} \\
\hline 1978 & 181,648 & 141,030 & 40,618 & 11,782 & 11,513 & 269 & 135,723 & 103,683 & 32,040 & 9,992 & 7,883 & 2,109 \\
\hline 1979 & 174,509 & 130,692 & 44,272 & 10,698 & 10,233 & 465 & 128,788 & 95,516 & 33,727 & 11,411 & 7,998 & 3,413 \\
\hline 1980 & 147,050 & 112,701 & 34,349 & 10,655 & 10,242 & 413 & 105,271 & 79,969 & 25,302 & 8,681 & 6,329 & 2,352 \\
\hline 1981 & 152,063 & 115,168 & 36,895 & 13,118 & 12,328 & 790 & 106,220 & 79,332 & 26,888 & 8,540 & 6,437 & 2,103 \\
\hline \multicolumn{13}{|l|}{1982} \\
\hline \multicolumn{13}{|l|}{1983} \\
\hline \multicolumn{13}{|l|}{1984} \\
\hline 1985 & 158,360 & 114,494 & 43,866 & 12,007 & 11,308 & 699 & 110,604 & 79,185 & 31,419 & 8,667 & 6,122 & 2,545 \\
\hline 1986 & 159,725 & 14,975 & 44,750 & 12,105 & 11,375 & 730 & 112,259 & 79,223 & 33,036 & 11,012 & 588 & 3,424 \\
\hline \multicolumn{13}{|l|}{1987} \\
\hline 1988 & 136,702 & 98,272 & 38,430 & 11,141 & 10,481 & 660 & 92,899 & 65,655 & 27,244 & 10,323 & 7,115 & 3,208 \\
\hline 1989 & 135,831 & 97,656 & 38,175 & 11,314 & 10,568 & 746 & 92,619 & 5,612 & 27,007 & 11,522 & 698 & 824 \\
\hline 1990 & 128,776 & 92,368 & 36,408 & 11,061 & 10,269 & 792 & 86,311 & 61,255 & 25,056 & 10,966 & 7,113 & 3,853 \\
\hline \multicolumn{13}{|l|}{1991} \\
\hline 1992 & 123,592 & 87,958 & 35,634 & 12,230 & 11,203 &, 027 & 82,133 & 7,145 & 24,988 & 9,754 & 6,568 & 3,186 \\
\hline 1993 & 128,665 & 90,916 & 37,749 & 11,582 & 10,712 & 870 & 87,541 & 60,488 & 27,053 & 10,269 & 6897 & 3372 \\
\hline 1994 & 112,364 & 78,398 & 33,966 & 10,421 & 9,546 & 875 & 76,158 & 51,588 & 24,570 & 10,516 & 7020 & 3496 \\
\hline 1995 & 115,450 & 79,029 & 36,421 & 9,963 & 9,076 & 887 & 78,008 & 52,271 & 25,737 & 11,842 & 7375 & 4467 \\
\hline 1996 & 124,553 & 83,312 & 41,241 & 10,868 & 9,559 & 1,309 & 81,655 & 53,374 & 28,281 & 14,004 & 8,692 & 5,312 \\
\hline 1997 & 128,488 & 85,448 & 43,040 & 11,142 & 9,910 & 1,232 & 86,855 & 56,423 & 30,432 & 13,688 & 8,262 & 5,426 \\
\hline 1998 & 129,369 & 84,752 & 44,617 & 10,682 & 9,402 & 1,280 & 86,095 & 55,368 & 30,727 & 14,250 & 8,425 & 5,825 \\
\hline 1999 & 131,730 & 85,042 & 46,688 & 10,701 & 9,226 & 1,475 & 86,640 & 54,926 & 31,714 & 15,481 & 9,090 & 6,391 \\
\hline 2000 & 125,223 & 81,428 & 43,795 & 9,878 & 8,659 & 1,219 & 82,251 & 52,481 & 29,770 & 14,962 & 8,938 & 6,024 \\
\hline 2001 & 120,796 & 77,715 & 43,081 & 8,928 & 7,811 & 1,117 & 79,829 & 50,243 & 29,586 & 14,248 & 8,592 & 5,656 \\
\hline 2002 & 112,365 & 72,402 & 39,963 & 8,825 & 7,605 & 1,220 & 73,290 & 46,195 & 27,095 & 13,035 & 7,689 & 5,346 \\
\hline 2003 & 113,496 & 70,721 & 42,775 & 8,703 & 7,382 & 1,321 & 73,976 & 44,577 & 29,399 & 14,420 & 8,475 & 5,945 \\
\hline 2004 & 110,711 & 69,232 & 41,479 & 8,230 & 7,009 & 1,221 & 70,670 & 42,918 & 27,752 & 14,971 & 8,751 & 6,220 \\
\hline 2005 & 112,428 & 70,300 & 42,128 & 8,072 & 6,896 & 1,176 & 74,363 & 45,190 & 29,173 & 13,565 & 7,909 & 5,656 \\
\hline 2006 & 99,955 & 62,335 & 37,620 & 7,081 & 6,010 & 1,071 & 67,069 & 40,572 & 26,497 & 11,593 & 6,819 & 4,774 \\
\hline 2007 & 95,291 & 58,938 & 36,353 & 6,283 & 5,296 & 987 & 62,986 & 37,801 & 25,185 & 11,744 & 7,059 & 4,685 \\
\hline 2008 & 83,002 & 51,214 & 31,788 & 5,384 & 4,540 & 844 & 55,173 & 33,030 & 22,143 & 9,366 & 5,729 & 3,637 \\
\hline 2009 & 59,508 & 36,979 & 22,529 & 3,836 & 3,218 & 618 & 39,563 & 23,983 & 15,580 & 6,631 & 3,987 & 2,644 \\
\hline 2010 & 60,354 & 37,881 & 22,473 & 3,765 & 3,184 & 581 & 40,010 & 24,601 & 15,409 & 7,449 & 4,529 & 2,920 \\
\hline 2011 & 68,712 & 43,844 & 24,868 & 4,027 & 3,350 & 677 & 46,141 & 28,946 & 17,195 & 8,273 & 5,106 & 3,167 \\
\hline 2012 & 77,249 & 49,443 & 27,806 & 4,578 & 3,756 & 822 & 51,982 & 32,616 & 19,366 & 9,257 & 5,881 & 3,376 \\
\hline 2013 & 87,920 & 55,791 & 32,129 & 4,662 & 3,887 & 775 & 59,360 & 36,782 & 22,578 & 11,316 & 7,180 & 4,136 \\
\hline 2014 & 95,798 & 61,179 & 34,619 & 5,385 & 4,510 & 875 & 63,418 & 39,382 & 24,036 & 13,056 & 8,392 & 4,664 \\
\hline 2015 & 104,583 & 66,512 & 38,071 & 6,767 & 5,612 & 1,155 & 68,033 & 42,123 & 25,910 & 15,058 & 9,326 & 5,732 \\
\hline
\end{tabular}

Source: EEOC, Job Patterns 1971-2015

Note: Blank rows are years for which EEO-1 data are not available. 
Table IV.14 shows the proportional representation of Black men and women in the auto labor force and its various occupational categories in the period 1971-2015. According to these EEO-1 data, Blacks were between 13 percent and 16 percent of all employees in the motor vehicle and equipment industry. In the early 1970s, Black women were a lower proportion of all female workers in autos compared with Black men as a percentage of all male workers, but the proportionate representation of Black females increased considerably from the late 1970s, and since then was 20 to 23 percent of all female auto employees, with the exception of 2008-2011 when the proportion fell to 18 or 19 percent.

Within occupational categories, Blacks were most highly represented among operatives, in which, over the 45-year period, their presence ranged from a low of 19.0 percent in 2010 to 24.0 percent in both 2014 and 2015, and then among laborers, ranging from 14.5 percent in 1985 to 24.1 in 2015. Blacks were less well represented among craft workers. After making progress in the 1970s, Blacks leveled out at seven to eight percent of all craft workers, with that proportion rising from 2012, reaching 11.1 percent in 2015. The number of blue-collar Blacks in autos fell dramatically since the late 1970s, but as of 2015 Blacks remained particularly well-represented as operatives and as laborers. The question is whether, in the twenty-first century, the blue-collar jobs that Blacks hold in this mass-production industry can still deliver a middle-class standard of living - a question to which we shall return.

Of the occupational categories not shown in Table IV.14, Blacks as a proportion of officials and managers went from 2.7 percent in 1971 to 6.4 percent in 1979 and then was between six percent and eight percent through 2015, except for 2009-2011, when the proportion fell to about 5.7 percent. In 2014 and 2015, Blacks as proportion of officials and managers were about the same as in 1979. In 1978, Black officials and managers were 3.6 percent of all Black employees in autos, up from 1.5 percent in 1971. This proportion was around four percent in the 1980s and 1990s, and then increased to as high as 4.9 percent in 2008 and stood at 3.6 percent in 2015.

Within this category, the proportions of Black women of all female officials and managers were between nine and 16 percent from 1975 through 2015, reaching a peak of 15.9 percent in 1988, up from 14.8 percent a decade earlier, but falling below ten percent from 2009 through 2013, and at only 10.1 percent in 2014 and 2015. Over the decades, this Black female representation among all female employees was about double the proportions of Black men of all male officials and managers. But Black men were much more numerous than Black women among officials and managers, with a ratio of about 8.5:1 in 1979-1981 declining to 2.6:1 in 2011-2015.

The proportional representation of Blacks in both the professionals and technicians categories was similar to that of officials and managers over the decades except for a sharp increase in Black representation among technicians in 2012-2015. In 2015, Blacks were 6.5 percent of officials and managers, 5.9 percent of professionals, 10.0 percent of technicians, and 3.7 percent of sales personnel. As proportions of all Black employees in autos in 2015, 3.6 percent of Blacks were officials and managers, 5.8 percent professionals, 2.3 percent technicians and 0.2 percent sales. 
Table IV.14: Blacks as percent of the total motor vehicle and equipment labor force and of selected occupational groups, 1971-2015

\begin{tabular}{|c|c|c|c|c|c|c|c|c|c|c|c|c|}
\hline & \multicolumn{3}{|c|}{ All black workers } & \multicolumn{3}{|c|}{ Craft workers } & \multicolumn{3}{|c|}{ Operatives } & \multicolumn{3}{|c|}{ Laborers } \\
\hline & Total & Male & Female & Total & Male & Female & Total & Male & Female & Total & Male & Female \\
\hline 1971 & 15.0 & 15.3 & 11.8 & 4.1 & 4.1 & 5.9 & 20.7 & 21.1 & 16.4 & 21.8 & 23.7 & 10.4 \\
\hline 1972 & & & & & & & & & & & & \\
\hline 1973 & 16.0 & 15.9 & 17.1 & 5.4 & 5.4 & 7.4 & 21.7 & 21.6 & 22.9 & 21.2 & 22.9 & 13.9 \\
\hline 1974 & & & & & & & & & & & & \\
\hline 1975 & 14.8 & 14.5 & 17.0 & 5.8 & 5.7 & 10.0 & 20.5 & 20.3 & 21.8 & 19.5 & 21.0 & 13.2 \\
\hline 1976 & & & & & & & & & & & & \\
\hline 1977 & & & & & & & & & & & & \\
\hline 1978 & 15.7 & 14.5 & 22.0 & 6.9 & 6.8 & 12.6 & 21.6 & 20.1 & 28.4 & 15.7 & 16.4 & 13.4 \\
\hline 1979 & 15.8 & 14.4 & 22.2 & 7.0 & 6.8 & 15.7 & 21.7 & 20.0 & 28.8 & 15.9 & 15.9 & 15.9 \\
\hline 1980 & 14.4 & 13.3 & 19.8 & 6.7 & 6.6 & 10.1 & 20.3 & 18.9 & 26.3 & 15.2 & 15.8 & 13.7 \\
\hline 1981 & 14.6 & 13.4 & 20.4 & 7.6 & 7.3 & 23.4 & 20.5 & 19.0 & 26.7 & 16.0 & 16.5 & 14.8 \\
\hline 1982 & & & & & & & & & & & & \\
\hline 1983 & & & & & & & & & & & & \\
\hline 1984 & & & & & & & & & & & & \\
\hline 1985 & 15.4 & 13.8 & 22.0 & 7.3 & 7.0 & 16.7 & 22.1 & 20.1 & 29.5 & 14.9 & 14.8 & 15.1 \\
\hline 1986 & 15.9 & 14.2 & 23.4 & 7.4 & 7.1 & 17.3 & 22.5 & 20.4 & 30.3 & 17.8 & 17.2 & 19.5 \\
\hline 1987 & & & & & & & & & & & & \\
\hline 1988 & 15.4 & 13.7 & 22.5 & 7.5 & 7.2 & 16.1 & 21.9 & 19.8 & 29.1 & 17.7 & 16.9 & 20.1 \\
\hline 1989 & 15.3 & 13.7 & 22.2 & 7.6 & 7.3 & 16.8 & 21.5 & 19.6 & 28.5 & 18.4 & 17.1 & 21.6 \\
\hline 1990 & 15.3 & 13.6 & 22.1 & 7.9 & 7.6 & 16.5 & 21.6 & 19.5 & 29.0 & 18.5 & 17.2 & 21.4 \\
\hline 1991 & & & & & & & & & & & & \\
\hline 1992 & 14.8 & 13.1 & 21.3 & 8.4 & 8.0 & 17.2 & 20.9 & 18.8 & 28.4 & 16.8 & 15.9 & 19.1 \\
\hline 1993 & 14.9 & 13.2 & 21.5 & 8.0 & 7.7 & 15.3 & 20.8 & 18.6 & 28.5 & 16.7 & 16.0 & 18.3 \\
\hline 1994 & 14.3 & 12.5 & 21.0 & 8.1 & 7.8 & 16.3 & 19.5 & 17.2 & 27.5 & 16.4 & 15.6 & 18.1 \\
\hline 1995 & 14.1 & 12.3 & 20.4 & 7.8 & 7.5 & 14.3 & 19.3 & 17.1 & 26.2 & 16.8 & 15.5 & 19.6 \\
\hline 1996 & 14.2 & 12.2 & 20.7 & 7.9 & 7.4 & 17.4 & 19.1 & 16.9 & 25.6 & 17.4 & 15.8 & 20.8 \\
\hline 1997 & 14.4 & 12.4 & 21.2 & 7.8 & 7.3 & 16.1 & 19.3 & 16.9 & 26.6 & 17.1 & 15.7 & 19.8 \\
\hline 1998 & 14.5 & 12.4 & 21.5 & 7.7 & 7.2 & 16.2 & 19.2 & 16.7 & 26.6 & 17.9 & 16.0 & 21.6 \\
\hline 1999 & 14.4 & 12.3 & 21.2 & 7.9 & 7.3 & 17.0 & 19.0 & 16.5 & 26.0 & 17.7 & 15.9 & 20.9 \\
\hline 2000 & 14.1 & 12.1 & 20.3 & 7.6 & 7.1 & 14.5 & 18.6 & 16.3 & 25.0 & 17.5 & 16.1 & 20.1 \\
\hline 2001 & 14.6 & 12.4 & 21.1 & 7.4 & 6.9 & 14.5 & 19.5 & 16.9 & 26.6 & 18.6 & 17.6 & 20.4 \\
\hline 2002 & 14.2 & 12.1 & 20.6 & 7.7 & 7.1 & 15.7 & 19.3 & 16.8 & 26.1 & 17.5 & 16.2 & 19.7 \\
\hline 2003 & 15.2 & 12.9 & 21.6 & 8.1 & 7.4 & 16.9 & 21.1 & 18.3 & 27.4 & 18.1 & 17.3 & 19.5 \\
\hline 2004 & 15.1 & 12.8 & 21.4 & 8.0 & 7.4 & 16.2 & 21.2 & 18.4 & 27.6 & 18.6 & 17.9 & 19.6 \\
\hline 2005 & 15.3 & 12.9 & 21.8 & 7.9 & 7.3 & 15.7 & 21.6 & 18.8 & 28.2 & 18.3 & 17.6 & 19.4 \\
\hline 2006 & 15.1 & 12.8 & 21.3 & 7.9 & 7.3 & 15.5 & 21.3 & 18.5 & 28.0 & 17.2 & 16.7 & 18.0 \\
\hline 2007 & 14.5 & 12.3 & 20.3 & 7.7 & 7.0 & 15.4 & 20.8 & 18.1 & 27.0 & 16.3 & 15.7 & 17.1 \\
\hline 2008 & 13.8 & 11.7 & 19.3 & 7.5 & 6.9 & 15.2 & 20.1 & 17.6 & 25.8 & 15.8 & 15.3 & 16.5 \\
\hline 2009 & 12.9 & 11.0 & 18.4 & 7.1 & 6.5 & 15.2 & 19.2 & 16.7 & 24.7 & 16.3 & 15.7 & 17.3 \\
\hline 2010 & 13.0 & 11.0 & 18.5 & 7.0 & 6.4 & 13.9 & 19.0 & 16.6 & 24.8 & 17.0 & 16.1 & 18.7 \\
\hline 2011 & 13.6 & 11.7 & 19.3 & 7.5 & 6.7 & 16.4 & 20.0 & 17.6 & 25.8 & 18.4 & 17.6 & 19.9 \\
\hline 2012 & 15.3 & 13.2 & 21.4 & 8.8 & 7.8 & 21.7 & 22.2 & 19.6 & 28.3 & 19.6 & 18.9 & 20.9 \\
\hline 2013 & 16.0 & 13.7 & 22.6 & 8.5 & 7.6 & 18.7 & 23.4 & 20.6 & 29.9 & 21.9 & 20.8 & 24.0 \\
\hline 2014 & 16.6 & 14.4 & 23.1 & 9.3 & 8.4 & 20.6 & 24.0 & 21.3 & 30.3 & 23.7 & 22.9 & 25.4 \\
\hline 2015 & 17.0 & 14.7 & 23.3 & 11.1 & 10.0 & 23.8 & 24.0 & 21.5 & 29.9 & 24.1 & 22.5 & 27.2 \\
\hline
\end{tabular}

Source: EEOC, Job Patterns 1971-2015

Note: Blank rows are years for which EEO-1 data are not available.

Black employment tended to decline in recessions, although our documentation of the extent of a decline is hampered by the lack of EEO-1 data for the recessionary years of 1982 and 1991. In the Great Recession, total Black employment plummeted from 95,291 in 2007 to 83,002 in 2008 and 59,508 in 2009, the year in which General Motors and Chrysler went bankrupt and were bailed out by the U.S. and Canadian governments and the UAW. Blacks were disproportionately affected by this decline, falling from 14.5 percent of all auto employees in 2007 to 12.9 percent in 2009. By 2015 the Black share had increased to 17.0 percent. Among operatives, the occupation in which 
by far the largest number of Blacks were employed, the Great Recession decline was from 20.8 percent in 2007 to 19.2 percent in 2009

Table IV.15 provides a rare glimpse at company-level EEO-1 data, in this case for 1990 and 1991. In 1993, Rochelle Sharpe used EEO-1 data to investigate the extent to which Blacks were thrown out of work by major companies in the recession of 1990-1991. ${ }^{75}$ Working for the Wall Street Journal, she obtained from the EEOC tapes with company-level EEO-1 data, but with the company names redacted. From this dataset, Sharpe was able to report that "blacks were the only racial group to suffer a net job loss during the 1990-91 economic downturn, at the companies reporting to the Equal Employment Opportunity Commission. Whites, Hispanics and Asians, meanwhile, gained thousands of jobs, according to a Wall Street Journal analysis of EEOC records."76

Sharpe was able to identify a large number of the companies by name by matching the employment data in the EEO-1 files with employment data in records of companies that served as U.S. government contractors, with the names revealed. Table IV.15 shows the top 30 employers of Blacks in 1990 among the companies that Sharpe identified. All 30 companies cut back on employment of Blacks in 1991 compared with 1990, ranging from net reductions of five Black employees at Eastman Kodak to 6,972 at Marriott. Combined these companies employed 456,879 Blacks in 1990 , reduced to 418,872 in $1991 .{ }^{77}$

To our knowledge, the Sharpe article provides the only public information available on the largest corporate employers of Blacks in the United States in any given year. Of the Big Three in autos, General Motors had the largest numbers of Black employees in 1990 and 1991, with Chrysler in sixth place in both years. Missing from the employers in Table IV.15 is Ford Motor Company, presumably because it was not on the list of government contractors that Sharpe used to identify the companies in the EEO-1 tapes. Data published in Ford Annual Reports for 1990 and 1991, however, provide us with the EEO data on Black employees. In 1990, there were 27,336 Blacks employed at Ford, which would place it fifth on the list in Table IV.15, ahead of McDonald's and just behind AT\&T. In 1991, this number fell slightly to 26,539 employees, which would have placed Ford fourth on the list in Table IV.15.78

Of the Big Three, Ford Motor Company has provided, in its annual reports, the most detailed data on the employment of Blacks, drawn from its EEO-1 reports. ${ }^{79}$ From 1978 through 2001, Ford published the proportional representation of Blacks in the nine occupational classifications displayed in Table IV.12 above. But Ford provided no employment numbers. From the data that Ford published, one can only derive Ford's total employment of Blacks from 1978 to 2000, as shown in Table IV.16. ${ }^{80}$

\footnotetext{
${ }^{75}$ Sharpe, "Losing ground."

${ }^{76}$ Ibid. See also Ruth Milkman, Farewell to the Factory: Auto Workers in the Late Twentieth Century, University of California Press, 1997, p. 133.

${ }^{77}$ If we had EEO-1 data for 1991, we could corroborate these findings from that source. Unfortunately, the EEOC did not publish its Jobs Patterns volume for 1991. In the Wall Street Journal article, Sharpe provides data for 96 companies.

${ }^{78}$ Ford Motor Company, Annual Report 1990, p. 40; Ford Motor Company, Annual Report 1991, p. 39.

${ }^{79}$ More limited data in General Motors' annual reports are not useful, while Chrysler did not provide any of its EEO-1 data.

${ }^{80}$ Ford annual reports provided data from 1972 through 1977, but only identified minorities as a group.
} 
Table IV.15: U.S. companies with largest Black workforces, 1990 , and changes in their Black employment, 1990 to 1991

\begin{tabular}{|l|c|c|c|}
\hline & $\begin{array}{c}\text { Black } \\
\text { employees, } \\
\mathbf{1 9 9 0}\end{array}$ & $\begin{array}{c}\text { Blacks as } \\
\text { percent of } \\
\text { total, } \mathbf{1 9 9 0}\end{array}$ & $\begin{array}{c}\text { Black } \\
\text { employees, } \\
\mathbf{1 9 9 1}\end{array}$ \\
\hline General Motors & 69,263 & 16.83 & 68,011 \\
\hline Sears Roebuck & 67,356 & 15.85 & 61,783 \\
\hline Marriott & 48,643 & 22.46 & 41,671 \\
\hline AT\&T & 27,450 & 16.38 & 24,497 \\
\hline McDonald's & 24,741 & 23.19 & 21,816 \\
\hline Chrysler & 20,704 & 20.66 & 20,052 \\
\hline IBM & 20,222 & 9.10 & 18,677 \\
\hline General Electric & 16,574 & 7.86 & 14,574 \\
\hline McDonnell-Douglas & 12,822 & 10.92 & 11,114 \\
\hline Georgia Pacific & 11,629 & 19.80 & 10,716 \\
\hline DuPont & 10,633 & 11.02 & 9,197 \\
\hline United Technologies & 9,265 & 9.00 & 8,882 \\
\hline Allied Signal & 8,648 & 11.44 & 8,232 \\
\hline Dial Corp & 8,274 & 26.29 & 6,829 \\
\hline Boeing & 8,126 & 5.20 & 7,983 \\
\hline Citicorp & 7,689 & 13.76 & 7,532 \\
\hline VF Corp & 7,130 & 16.77 & 6,907 \\
\hline Fruit of the Loom & 7,006 & 27.88 & 6,853 \\
\hline Safeway & 6,840 & 8.62 & 6,736 \\
\hline General Dynamics & 6,414 & 6.35 & 5,699 \\
\hline Chase Manhattan & 6,407 & 21.06 & 6,109 \\
\hline USX & 6,403 & 12.55 & 5,500 \\
\hline Anheuser-Busch & 5,985 & 12.13 & 5,975 \\
\hline Cooper Industries & 5,880 & 13.26 & 5,709 \\
\hline Lockheed & 5,657 & 7.04 & 4,697 \\
\hline Martin Marietta & 5,627 & 8.76 & 5,338 \\
\hline Chemical Bank & 5,582 & 20.52 & 5,536 \\
\hline Eastman Kodak & 5,570 & 7.37 & 5,565 \\
\hline Rockwell International & 5,302 & 6.20 & 4,788 \\
\hline Flour & 5,037 & 11.67 & 1,894 \\
\hline Sour: Rochele Shape, & $0579564 n d$ & \\
\hline
\end{tabular}

Source: Rochelle Sharpe, "Losing ground: In latest recession, only blacks suffered net employment loss," Wall Street Journal, September 14, 1993, A1. 
Table IV.16: Employment of Blacks, Ford Motor Company, 1978-2000

\begin{tabular}{|c|c|c|c|c|c|}
\hline & Total hourly & $\begin{array}{c}\text { Total } \\
\text { salaried }\end{array}$ & $\begin{array}{c}\text { Hourly as } \\
\text { of all } \\
\text { employees }\end{array}$ & Total Black & $\begin{array}{c}\text { Blacks as \% of } \\
\text { all } \\
\text { employees }\end{array}$ \\
\hline $\mathbf{1 9 7 8}$ & 204,100 & 85,300 & 70.5 & 50,934 & 17.6 \\
\hline $\mathbf{1 9 7 9}$ & 160,900 & 82,900 & 66.0 & 39,008 & 16.0 \\
\hline $\mathbf{1 9 8 0}$ & 135,600 & 72,000 & 65.3 & 32,593 & 15.7 \\
\hline $\mathbf{1 9 8 1}$ & 118,200 & 70,900 & 62.5 & 28,176 & 14.9 \\
\hline $\mathbf{1 9 8 2}$ & 106,800 & 69,400 & 60.6 & 24,844 & 14.1 \\
\hline $\mathbf{1 9 8 3}$ & 115,300 & 68,400 & 62.8 & 27,555 & 15.0 \\
\hline $\mathbf{1 9 8 4}$ & 118,600 & 68,800 & 63.3 & 28,860 & 15.4 \\
\hline $\mathbf{1 9 8 5}$ & 116,900 & 67,800 & 63.3 & 29,183 & 15.8 \\
\hline $\mathbf{1 9 8 6}$ & 115,500 & 66,600 & 63.4 & 29,318 & 16.1 \\
\hline $\mathbf{1 9 8 7}$ & 113,900 & 66,600 & 63.1 & 29,422 & 16.3 \\
\hline $\mathbf{1 9 8 8}$ & 113,500 & 66,000 & 63.2 & 29,797 & 16.6 \\
\hline $\mathbf{1 9 8 9}$ & 108,200 & 66,900 & 61.8 & 28,716 & 16.4 \\
\hline $\mathbf{1 9 9 0}$ & 106,000 & 54,800 & 65.9 & 27,336 & 17.0 \\
\hline $\mathbf{1 9 9 1}$ & 102,800 & 52,400 & 66.2 & 26,539 & 17.1 \\
\hline $\mathbf{1 9 9 2}$ & 102,800 & 53,500 & 65.8 & 26,258 & 16.8 \\
\hline $\mathbf{1 9 9 3}$ & 104,700 & 54,900 & 65.6 & 26,813 & 16.8 \\
\hline $\mathbf{1 9 9 4}$ & 109,500 & 55,800 & 66.2 & 28,101 & 17.0 \\
\hline $\mathbf{1 9 9 5}$ & 105,261 & 54,660 & 65.8 & 27,666 & 17.3 \\
\hline $\mathbf{1 9 9 6}$ & 105,472 & 54,999 & 65.7 & 27,761 & 17.3 \\
\hline $\mathbf{1 9 9 7}$ & 103,569 & 53,305 & 66.0 & 27,139 & 17.3 \\
\hline $\mathbf{1 9 9 8}$ & 100,760 & 53,309 & 65.4 & 26,808 & 17.4 \\
\hline $\mathbf{1 9 9 9}$ & 102,964 & 54,796 & 65.3 & 28,712 & 18.2 \\
\hline $\mathbf{2 0 0 0}$ & 103,560 & 45,822 & 69.3 & 27,636 & 18.5 \\
\hline
\end{tabular}

Source: Ford Motor Company, Annual Reports, 1979-2001.

Blacks were hit disproportionately in the recession of 1980-1982. From 1978 to 1982 total employment at Ford fell by 39 percent, hourly employment by 48 percent, and Black employment by 51 percent. In 1978, Ford had employed almost 51,000 Blacks, representing 17.6 percent of Ford's U.S. labor force, as reported to the EEOC. In 1982, the number of Blacks employed at Ford had plummeted to less than 25,000, which was only 14.1 percent of all Ford's U.S. employees. Black employment then increased until 1988, when it was just under 30,000, before it declined steadily by over 3,500 from 1988 to 1992 . It then increased to a new high of just over 28,000 in 1994 and fluctuated between 26,000 and 28,000 through 2000. In that year, blacks were 18.5 percent of Ford's labor force, but the number of Black employees had declined from 289,400 in 1978 to 149,400 in 2000.

Table IV.17 shows the proportions of the different EEO-1 job classifications held by Blacks at Ford for 1978 through 2001. Blacks were consistently around one-quarter of all operatives at Ford, even as there were dramatic reductions in the number of hourly workers whom Ford employed. Over the 24 years, the proportions of laborers and service workers who were Black increased, with Blacks representing about one-third of all employees in 2001. 
Blacks remained a small proportion of all craft workers throughout, ranging from 6.1 percent in 1982 to 9.1 percent in the first half of the 1990s. Black presence among office and clerical workers increased proportionately over the whole period, rising from a low of 13.1 percent in 1983 to 22.2 percent in 2001. Blacks had low but generally rising shares of jobs as officials and managers, professionals, and technicians, with the highest percentages for all three categories being achieved in 2001. At that point, Ford ceased to present the EEO-1 data in its annual reports.

Table IV.17: Ford Motor Company, Black employees in the United States and Blacks as proportions of the company's labor force in EEO-1 job classifications, 1978-2001

\begin{tabular}{|c|c|c|c|c|c|c|c|c|c|c|}
\hline & \multirow{2}{*}{$\begin{array}{c}\text { Number of } \\
\text { Black } \\
\text { employees }\end{array}$} & \multicolumn{9}{|c|}{ Blacks as a percentage of all workers by occupational category } \\
\hline & & $\begin{array}{c}\text { Total } \\
\text { Workforce }\end{array}$ & $\begin{array}{c}\text { Officials and } \\
\text { Managers }\end{array}$ & $\begin{array}{l}\text { Profes- } \\
\text { sionals }\end{array}$ & Technicians & $\begin{array}{c}\text { Office and } \\
\text { Clerical }\end{array}$ & $\begin{array}{c}\text { Craft } \\
\text { Workers }\end{array}$ & Operatives & Laborers & $\begin{array}{c}\text { Service } \\
\text { Workers }\end{array}$ \\
\hline 1979 & 39,008 & 16.0 & 6.4 & 5.3 & 5.1 & 13.3 & 7.0 & 24.9 & 27.6 & 23.7 \\
\hline 1980 & 32,593 & 15.7 & 6.1 & 5.0 & 5.1 & 13.5 & 7.1 & 24.8 & 27.5 & 24.7 \\
\hline 1983 & 27,555 & 15.0 & 6.3 & 4.9 & 6.4 & 13.1 & 6.7 & 24.4 & 25.1 & 25.7 \\
\hline 1984 & 28,860 & 15.4 & 6.9 & 5.2 & 6.4 & 13.7 & 7.2 & 25.0 & 25.5 & 25.8 \\
\hline 1985 & 29,183 & 15.8 & 7.3 & 5.4 & 6.7 & 13.8 & 7.7 & 25.4 & 26.1 & 25.7 \\
\hline 1986 & 29,318 & 16.1 & 7.5 & 5.5 & 6.0 & 13.6 & 7.6 & 26.0 & 27.1 & 25.9 \\
\hline 1987 & 29,422 & 16.3 & 7.5 & 5.8 & 6.2 & 14.4 & 7.8 & 26.2 & 26.8 & 27.0 \\
\hline 1991 & 26,539 & 17.1 & 8.1 & 6.9 & 7.3 & 15.9 & 8.9 & 26.3 & 27.0 & 26.3 \\
\hline 1992 & 26,258 & 16.8 & 8.3 & 6.8 & 7.5 & 16.2 & 9.1 & 25.9 & 27.2 & 26.7 \\
\hline 1993 & 26,813 & 16.8 & 8.4 & 7.0 & 7.3 & 16.5 & 9.0 & 25.4 & 28.1 & 26.5 \\
\hline 1994 & 28,101 & 17.0 & 8.6 & 7.1 & 7.2 & 16.8 & 9.1 & 25.2 & 28.0 & 26.9 \\
\hline 1995 & 27,666 & 17.3 & 8.9 & 7.5 & 6.9 & 17.1 & 9.1 & 26.0 & 30.3 & 27.9 \\
\hline 1996 & 27,761 & 17.3 & 8.7 & 7.7 & 6.9 & 17.4 & 9.0 & 25.8 & 29.3 & 28.6 \\
\hline 1997 & 27,139 & 17.3 & 8.7 & 7.9 & 7.1 & 17.5 & 8.9 & 25.6 & 31.5 & 29.7 \\
\hline 1998 & 26,808 & 17.4 & 9.0 & 8.1 & 7.3 & 18.1 & 8.4 & 25.7 & 30.8 & 31.5 \\
\hline 1999 & 28,712 & 18.2 & 9.7 & 8.9 & 8.5 & 18.7 & 8.3 & 26.7 & 31.4 & 32.3 \\
\hline
\end{tabular}

Source: Ford Motor Company, Annual Reports, 1978-2000.

Ford provided data on average hourly wages and benefits of its unionized employees in its annual reports from 1959 through 2006. In Figure IV.2, we have set both the real hourly wage and real hourly benefits to 100 in 1979, since that was the peak year of membership of the UAW before it entered into its long-run decline. From 1979 through 1997 the average real hourly wage at Ford was stagnant; in 1995, 1996, and 1997 it was at virtually the same level as in 1979. Subsequently, it increased to a level about 14 percent higher in 2002-2006 than the 1979 benchmark. Much more of the gains to UAW members came in the form of retirement and health benefits, which exceeded the 1979 level by 38 percent in 1989, 70 percent in 1999, and 146 percent in 2006.

After 2006, Ford ceased publishing these figures, most likely because, with $\$ 12.6$ billion in losses in 2006 on a decline in revenues from $\$ 176.8$ billion to $\$ 160.1$ billion in that year, the company was in turmoil. Ford slashed its global employment from 300,000 at the end of 2005 to 283,000 a year later, and then kept on reducing its workforce until it reached as low as 164,000 in 2011 and 2012. At the end of 2020, Ford employed 186,000 worldwide. Of these employees, 58,000 were 
hourly workers represented by the UAW, less than 30 percent of the number of UAW members at Ford in 1978.

Figure IV.2: Ford Motor Company, average real hourly wage and benefits, U.S. hourly employees, 1959-2006

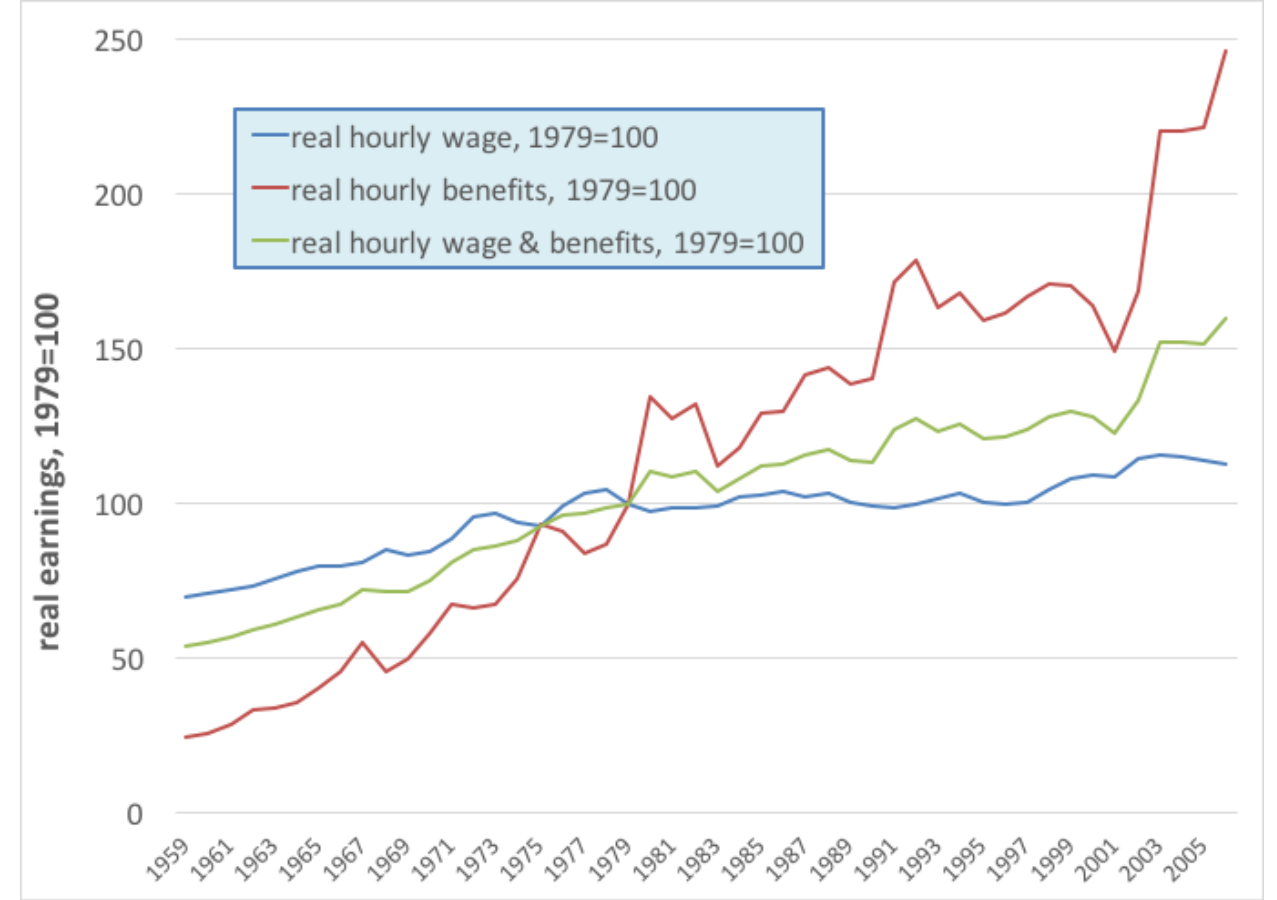

Source: Ford Motor Company Annual Reports or 10-K SEC Filings, 1959-2006.

As we have seen, the UAW's total membership peaked in 1979 at 1.5 million members and over the following three decades declined dramatically, reaching a low of 355,191 members in $2009 .{ }^{81}$ Between 2009 and 2017 membership increased to 430,871. Despite this modest growth, however, the increase in membership largely came from peripheral or unrelated industries, such as auto parts and suppliers, gaming, and higher education. ${ }^{82}$ These jobs either provide far less pay than auto assembly jobs or, due to substantial differences in educational and training requirements, fail to provide the same foothold in a career for high-school-educated blue-collar workers that auto employment once had. The collapse of UAW membership has followed the general process of deunionization in the United States, with employers utilizing substantial bargaining power gained from increased outsourcing and offshoring to achieve concessions in wages, benefits, and working conditions. As Jeffrey Rothstein has documented in three North American GM plants, for example, executives have "...used the threat of plant closure to whipsaw local unions against one another in a competition to match the productivity at the nonunion transplants." 83

\footnotetext{
${ }^{81}$ David Shepardson, "UAW says membership rose 1.8 percent in 2016," Reuters, April 4, 2017, at https://www.reuters.com/article/us-usa-labor/uaw-says-membership-rose-1-8-percent-in-2016-idUSKBN177047

${ }^{82}$ UAW, "UAW Grows by Almost 15,000 New Members in 2017; 75,000 New Members Since 2009," UAW News Release, March 29, 2018, at https://uaw .org/uaw-grows-almost-15000-new-members-2017-75000-new-members-since-2009/. For example, in 2018, the UAW successfully organized graduate students at Harvard University. Danielle Douglas-Gabrielle, "Harvard agrees to negotiate a contract with graduate-student union," Washington Post, May 1, 2018, at https://www.washingtonpost.com/news/grade-point/wp/2018/05/01/harvard-agrees-to-negotiate-a-contract-with-graduatestudent-union/?utm term=.d99391eb4bb1

${ }^{83}$ Jeffrey S. Rothstein, When Good Jobs Go Bad: Globalization, De-unionization, and Declining Job Quality in the North American Auto Industry, Rutgers University Press, 2016, p. 96
} 
In addition to pitting unions against nonunion plants, auto industry executives have also sought to divide unions internally, particularly through the introduction of separate wage tiers. The twotiered wage system was first introduced in the auto industry in the 1980s, when Ford and GM executives sought to limit the pay of UAW members working in auto parts compared to their higher-paid peers working in assembly. ${ }^{84}$ In the 2000s, however, particularly following the government bailout and restructuring of GM and Chrysler in 2009, auto industry executives and government officials aggressively sought to expand two-tier, and even three-tier, wage systems to new hires across departments. ${ }^{85}$ By continuing to provide senior workers with high wages and benefits, the older generation of workers was largely pacified. Meanwhile, younger workers, facing uncertain job prospects, have few if any alternatives to the reduced wages and benefits offered by the auto industry. ${ }^{86}$

At present, the state of auto-industry employment remains stark. As plants have followed cheap labor, both across national borders and to the largely non-union South, job quality has continued to deteriorate. According to a 2014 analysis by Catherine Ruckelshaus and Sarah Leberstein, 72 percent of autoworkers were employed in the parts sector, where median wages are 36 percent less than those in assembly ${ }^{87}$ Between 2003 and 2013, in fact, adjusting for inflation, while wages in manufacturing overall declined by 4.4 percent, wages in auto parts and assembly fell by 13.7 and 21.0 percent, respectively. ${ }^{88}$

Indeed, ten years after the onset of the Great Recession, despite having increased by roughly $\$ 2$ per hour since their 2013 low, the average hourly earnings of auto industry production and nonsupervisory workers stood at approximately $\$ 22.50$ per hour, precisely where the wage was in late 2008.$^{89}$ As Peter Waldman reported in Bloomberg Businessweek, while some have sought to cast the emergence of automotive manufacturing in the American South as the "New Detroit," the reality is that this employment is characterized by low pay, marginal benefits, and a paucity of

\footnotetext{
${ }^{84}$ See, e.g., Paul A. Eisenstein, “GM's housecleaning goes beyond closings,” Michigan Business, April 1, 1987; “GM's top negotiator says automakers considering two-tier wages," Associated Press, May 28, 1987; Janet Braunstein, "GM's first contract proposal not well-received by UAW," Associated Press, August 12, 1987.

${ }^{85}$ Jim Stanford, "The Geography of Auto Globalization and the Politics of Auto Bailouts," Cambridge Journal of Regions, Economy, and Society, 3, 3, 2010: 383-405; Austan D. Goolsbee and Alan B. Krueger, "A Retrospective Look at Rescuing and Restructuring General Motors and Chrysler," Journal of Economic Perspectives, 29, 2, 2015: 2-23; Joseph R. Szczensy, “Third wage tier gains foothold at four GM plants," Wards Auto, March 30, 2015, at https://www.wardsauto.com/industry/third-wagetier-gains-foothold-four-gm-plants

${ }^{86}$ Louis Uchitelle, "Diminishing expectations: 'Two-tier' union contracts have opened a gulf between generations," The Nation, February 25, 2013: 18-20; Greg Gardner and Brent Snavely, "UAW, FCA officials miscalculated young worker angst," Detroit Free Press, October 5, 2015, at https://www.freep.com/story/money/cars/chrysler/2015/10/03/uaw-fca-officials-miscalculatedyoung-worker-angst-united-auto-workers/73291332/. For a journalistic account of the effect of the bailout of auto workers in Detroit, see Jonathan Mahler, "G.M., Detroit and the fall of the black middle class," New York Times, June 28, 2009, at http://www.nytimes.com/2009/06/28/magazine/28detroit-t.html. See also William Lazonick and Matt Hopkins, "GM's Stock Buyback Is Bad for America and the Company," Harvard Business Review, March 11, 2015, at https://hbr.org/2015/03/gmsstock-buyback-is-bad-for-america-and-the-company.

${ }^{87}$ Catherine Ruckelshaus and Sarah Leberstein, "Manufacturing Low Pay: Declining Wages in the Jobs That Built America's Middle Class," National Employment Law Project, November 2014, p. 9, at https://www.nelp.org/publication/manufacturinglow-pay-declining-wages-in-the-jobs-that-built-americas-middle-class/.

${ }^{88}$ Ibid., pp. 10-11

${ }^{89}$ Bureau of Labor Statistics, "Employment, Hours, and Earnings from the Current Employment Statistics Survey (National)," data gathered August 19, 2018, at https://data.bls.gov/timeseries/CEU3133600108?amp\%253bdata tool=XGtable\&output view=data\&include graphs=true
} 
workforce training. Unsurprisingly, such conditions have resulted in a host of disfiguring and even fatal industrial accidents..$^{00}$

\section{The decline of government-sector employment opportunity}

As with employment in the business sector, the auspicious developments of the $1960 \mathrm{~s}$ and the 1970s that led to improved access to better jobs for African Americans in state and local government and civil-society organizations in large part reversed course from the 1980s. Many metropolitan areas in which Blacks were concentrated had a substantial manufacturing base going into the 1980s. As we have discussed, this industrial base shrank in the 1980-1982 recessionary period, throughout the rest of the 1980s, and beyond. ${ }^{91}$ As a result, the tax bases of state and local governments contracted in many key cities for Black employment. State and local governments had to cut back employment as, unlike the federal government, state and local agencies cannot deficit spend for operating expenses.

Several policy choices during this time also had a dampening effect on employment of African Americans in state and local government agencies. President Reagan initiated budgets that cut federal spending for aid to state and local governments. Federal spending for social welfare declined in particular, as Reagan led an effort to roll back the Great Society programs and related initiatives of the previous two decades for redressing discrimination and low incomes. ${ }^{92}$ In addition, the Reagan administration encouraged declines in the enforcement of anti-discrimination legislation and equal employment opportunity policy. To make matters worse, the movement to restrict the growth of local property taxes, and hence state and local budgets, gained traction with the passage of Proposition 13 in California in 1978. Since that time, a majority of states have instituted some form of tax or expenditure limitation. ${ }^{93}$

The combined result of these changes in policy and funding was an end to the exceptional growth of employment in state and local governments that had occurred in the previous two decades. The percent growth rate of state and local government employment was 61.5 percent in the 1960s and 35.0 percent in the $1970 \mathrm{~s}$, but then declined to just 13.8 percent in the $1980 \mathrm{~s}, 17.8$ percent in the 1990 s, and 8.9 percent in the 2000s. ${ }^{94}$

The proportion of all non-agricultural employment that was employment in state and local government was 11.2 percent in 1960, 12.6 percent in 1965, and 13.8 percent in 1970 . The highwater mark was 15.5 percent in 1975, and then declined to 14.8 percent in $1980,14.0$ percent in 1984 and 13.7 percent in 1989. From 1990 to the Great Recession, the percent hovered around

\footnotetext{
${ }^{90}$ Peter Waldman, “Inside Alabama's auto jobs boom: Cheap wages, little training, crushed limbs," Bloomberg Businessweek, March 23, 2017, at https://www.bloomberg.com/news/features/2017-03-23/inside-alabama-s-auto-jobs-boom-cheap-wageslittle-training-crushed-limbs

${ }^{91}$ Manufacturing employment fell 6.8 percent from 1979 to 1989. See Lois M. Plunkert, "The 1980s: A Decade of Job Growth and Industry Shifts," Monthly Labor Review, September 1990: 3-16, at https://www.bls.gov/opub/mlr/1990/09/art1full.pdf.

${ }^{92}$ D. Lee Bawden and John L. Palmer, "Social Policy: Challenging the Welfare State," in John L. Palmer and Isabel Sawhill, eds., The Reagan Record: An Assessment of America's Changing Domestic Priorities, Ballinger, 1984: 177-216

${ }^{93}$ Kim S. Rueben and Megan Randal, "Tax and Expenditure Limits: How States Restrict Revenues and Spending," Urban Institute, November 27, 2017.

${ }^{94}$ Our calculations from U.S. Council of Economic Advisers, The Economic Report of the President 2000, Government Printing Office 2000, TABLE B-44: Employees on nonagricultural payrolls, by major industry, 1950-99; U.S. Council of Economic Advisers, The Economic Report of the President 2016, Government Printing Office 2016, TABLE B-14: Employees on nonagricultural payrolls, by major industry, 1972-2015.
} 
14.0 percent. ${ }^{95}$ As noted in our Working Paper No. 2 of this series,${ }^{96}$ employment in state and local government declined significantly because of the Great Recession, with disproportionate suffering for Blacks. ${ }^{97}$

The federal government funded much of the spending by state and local government agencies on social welfare activities as well as the social programs administered by civil-society organizations during the 1960s and 1970s, each of which were an advantageous source of professional and administrative jobs for Blacks. ${ }^{98}$ Part of the so-called "Reagan Revolution" was a reorientation of the social policy of the previous two decades. The president attempted to reduce the scope of social programs, change the emphasis from services and assistance to promoting work, and devolve responsibility for social programs from the federal government to the states. ${ }^{99}$ The changes in federal spending in the first four years of the Reagan administration in the areas most favorable to generating professional and administrative jobs for Blacks in state and local government agencies and government-funded programs run by civil society organizations are given in Table IV.18. The cuts were substantial.

Detroit, Baltimore, St. Louis, Cleveland, Cincinnati, and Milwaukee are cities that have particularly large populations of African Americans. ${ }^{100}$ Manufacturing industries, which played an important role providing industrial bases for these cities during the 1960s, took a beating in the late 1970s and 1980s. The loss of manufacturing jobs, many of which paid relatively well, reduced the tax bases of these cities, squeezing the budgets of local governments that had helped provide good jobs to Black residents.

\footnotetext{
${ }^{95}$ Our calculations from U.S. Council of Economic Advisers, The Economic Report of the President 2000, TABLE B-44.Employees on nonagricultural payrolls, by major industry, 1950-99; U.S. Council of Economic Advisers, The Economic Report of the President 2016, TABLE B-14. Employees on nonagricultural payrolls, by major industry, 1972-2015.

${ }^{96}$ Philip Moss, William Lazonick, and Joshua Weitz, "Employment and Earnings of African Americans Fifty Years After: Progress?" Institute for New Economic Thinking Working Paper No. 129. July 13, 2020, at https://www.ineteconomics.org/research/research-papers/employment-and-earnings-of-african-americans-fifty-years-afterprogress.

${ }^{97}$ David Cooper, Mary Gable, and Algernon Austin "The public-sector jobs crisis: Women and African Americans hit hardest by job losses in state and local governments," Economic Policy Institute Briefing Paper \#339, May 2012. See, in particular, Figures $\mathrm{B}$ and $\mathrm{G}$.

${ }^{98}$ See, e.g., Bennett Harrison, "Ghetto Employment and the Model Cities Program," Journal of Political Economy. 82, 2, Part 1, 1974: 353-371.

${ }^{99}$ Bawden and Palmer, The Reagan Record.

${ }^{100}$ U.S. Bureau of the Census, "The Black Population: 2010," 2010 Census Briefs, C2010BR-06, September, 2011, Tables 6 and 7, pp. 14-15, at https://www.census.gov/prod/cen2010/briefs/c2010br-06.pdf; "Metro Areas with Largest African American Population," Black Demographics, African American Population Report, at http://blackdemographics.com/population/blackcity-population/.
} 
Table IV.18: Change in U.S. federal spending, 1980 and 1984

\begin{tabular}{|c|c|c|c|}
\hline \multirow{2}{*}{ Social Welfare } & \multicolumn{2}{|c|}{ \$billions in 1980 dollars } & $\begin{array}{c}\text { \% change } \\
\text { 1980-1984 }\end{array}$ \\
\cline { 2 - 3 } & $\mathbf{1 9 8 0}$ & $\mathbf{1 9 8 4}$ & -35 \\
\hline Social Services & 28.5 & 18.6 & -22 \\
\hline Employment and Training & 10.3 & 5.7 & -60 \\
\hline Community Development & 10.8 & 8.1 & -19 \\
\hline Education and Research & 27.0 & 17.1 & -37 \\
\hline Elementary, Secondary & 7.0 & 5.4 & -23 \\
\hline Higher Education & 10.4 & 6.9 & -34 \\
\hline Research & 4.7 & 4.8 & 2 \\
\hline Health Services & 4.0 & 3.1 & -23 \\
\hline
\end{tabular}

Source: Lester M. Salamon, "Non-Profit Organizations:

The Lost Opportunity,' in John L. Palmer and Isabel

V. Sawhill, eds., The Reagan Record: An Assessment

of America's Changing Domestic Priorities, The

Urban Institute, 1984, Table 8.2, p. 277.

The experience of St. Louis provides a particularly useful case study for observing the impact of city cutbacks on Black municipal employment because in 1990 Blacks were 47.1 percent of the city's population and 44.8 percent of its workforce. ${ }^{101}$ At the beginning of 1970 , manufacturing employment in St. Louis was 288,300. At the end of 2002, it was 167,100, a decline of 121,000 jobs, of which 54,000 were lost from 1980 to $1990 .{ }^{102}$ This loss of employment undercut the city and state tax bases. To make raising revenue for city and state government even more difficult, Missouri amended its constitution in 1980 to put limits on the growth of expenditures and tax collections..$^{103}$

Using EEO-4 data, Lana Stein conducted a study of municipal employment in St. Louis, including the employment of African Americans in city government from 1979 to $1990 .{ }^{104}$ A combination of service reductions, contracting out, and privatization led to a drop in full-time employment by city government in St. Louis by 58 percent from 8,523 jobs in 1979 to 3,618 in 1990. Blacks absorbed a 66-percent decline in this employment while for whites it was 37 percent. As a result, the Black share of these municipal jobs fell from 55.5 percent in 1979 to 44.0 percent in 1990, representing a loss of 3,138 jobs. ${ }^{105}$ Stein argues that lack of seniority was a prime reason why Blacks were hurt more than whites when cities such as St. Louis slashed their labor forces during the 1980s. ${ }^{106}$

\footnotetext{
${ }^{101}$ Lana Stein, "Privatization, Work-Force Cutbacks, and African-American Municipal Employment,"American Review of Public Administration. 24, 2, 1994: 181-186, at 182.

${ }^{102}$ U.S. Bureau of Labor Statistics, "State and Area Employment Hours and Earnings (SIC) (Not seasonally adjusted)," Current Employment Statistics, at https://data.bls.gov/pdq/SurveyOutputServlet.

103 This amendment is known as the Hancock Amendment. Bridget Kevin-Myers and Russ Hembree, "The Hancock Amendment: Missouri's Tax Limitation Measure," Missouri Legislative Academy, Institute of Public Policy, University of Missouri, November 2012, at https://truman.missouri.edu/sites/default/files/publication/17-2012-hancock-amendment.pdf

${ }^{104}$ Stein, "Privatization."

${ }^{105}$ Our calculations based on the data presented in Lane, "Privatization," p. 185. It is impossible from this information to estimate how many Blacks regained employment by transfer elsewhere in city government or at non-government establishments.

${ }^{106}$ Stein, "Privatization," p. 184.
} 
A major source of job loss for Black municipal employees in St. Louis during this period occurred when the city closed its two city-owned hospitals and its health clinics. ${ }^{107}$ In 1979, Blacks comprised 74 percent of the employees in the city hospitals and 53 percent of all African American city employees worked in the hospital division. Only 23 percent of white city employees worked in the hospital division. Stein estimates that closing the city hospitals eliminated the jobs of almost half of the Black municipal employees of St. Louis. ${ }^{108}$

From the 1980s on, the reversal of opportunity in St. Louis for Blacks to find jobs with the city government was very harsh. While not necessarily of the same magnitude, Blacks in cities such as Detroit, Baltimore, Cleveland, Milwaukee as well as many smaller cities with substantial manufacturing employment prior to the 1980s suffered a similar fate. The study of St. Louis was done with EEO-4 data on state and local government employees, which have not been readily available for research. If the EEOC permitted broader access to these data, comparative studies of the experience across cities could be carried out.

In our Working Paper No. 2 of this series, Figures II.4 and II.5 show the time path of African American representation in state and local government employment continuing into the $2000 \mathrm{~s} .{ }^{109}$ Figure II.3 displays the African American share of jobs in the state and local government sector and the business sector from 1980 to 2011 and shows a government-sector steady decline from 15.1 percent in 1997 to 12.8 percent in 2011. The Great Recession precipitated a sharp fall. Figure II.5 shows the Black share of lower-earning and higher-earning state and local jobs in the 100 largest metropolitan areas from 1960 to 2008. The Black share of lower-earning jobs peaked in the late 1970s and began a steady decline in the mid-1990s. For higher-earning jobs, the Black share started to drop in the early 1990s. In sum, the government sector continues to provide Blacks with more opportunity than the business sector for better jobs and higher pay, given education and experience. The scope of this opportunity expanded following the Civil Rights Act of 1964 but has declined since the 1980s.

\section{Blacks in the military}

On July 26, 1948, President Harry Truman signed Executive Order 9981, mandating the racial desegregation of the U.S. Armed Forces. ${ }^{110}$ Nevertheless, research on the experience of Black soldiers in the military prior to the Vietnam War has documented their segregation, disparate deployment, and maltreatment in wartime. Despite these high hurdles, there has been recognition of the heroism shown by many Black soldiers. ${ }^{111}$

\footnotetext{
${ }^{107}$ The city entered into a shared funding privatization arrangement with surrounding county hospitals and health facilities. Ibid.

${ }^{108}$ Ibid. Lane estimates that roughly two-thirds of all hospital employees displaced by the closing found employment elsewhere. She does not give figures on reemployment of Black versus white employees, nor on the likely wages in the new jobs compared to the city hospital jobs. Although she does not indicate how she derived these estimates, it appears that they are based on interviews with hospital administrators.

${ }^{109}$ Moss et al., "Employment and Earnings of African Americans."

${ }^{110}$ President Harry S. Truman, Executive Order 9981, "Desegregation of the Armed Forces," July 26, 1948; General Records of the United States Government; Record Group 11; National Archives, at https://www.ourdocuments.gov/doc.php?flash=false\&doc=84.

111 See Gerry J. Gilmore, “African-Americans continue tradition of distinguished service,” U.S. Army News Service, Feb. 2 , 2007, at https://www.army.mil/article/1681/african americans continue tradition of distinguished service; "Military history of African Americans," Wikipedia, at https://en.wikipedia.org/wiki/Military history of African Americans; "Racial segregation in the United States Armed Forces, Wikipedia, at https://en.wikipedia.org/wiki/Racial segregation in the United States Armed Forces; "Racism against African Americans in the U.S. military," Wikipedia, at https://en.wikipedia.org/wiki/Racism against African Americans in the U.S. military.
} 
In our previous Black-employment working paper, we discussed the differential situation and experience of Blacks during the Vietnam War. ${ }^{112}$ Shrunken levels of benefits from the G.I. Bill and the slack employment situation in the 1970s resulted in high levels of unemployment and low earnings for Blacks as well as whites upon return from duty. By 1973, a little less than half of white veterans and only one-quarter of Black veterans claimed education benefits, and college graduation rates by 1980 among those who did claim these benefits were estimated to be 60.2 percent for whites but only 36.4 percent for Blacks. ${ }^{113}$ During the 1970 s and early 1980s, Vietnamera veterans realized no gains in their earnings from having served. Using longer run data, Joshua Angrist, Stacey Chen, and Jae Song found that by the 1990s, the difference in earnings between Vietnam veterans and non-veterans was negligible. White Vietnam veterans earned less than white non-veterans, while Black veterans earned slightly more than Black non-veterans. ${ }^{114}$

The end of conscription in 1973 brought a significant change in the rates of Black enlistment in the military. As shown in the top panel of Table IV.19, in 1973 Blacks comprised 14.0 percent of active enlisted members across all branches of the Armed Forces and 19.1 percent members in the Army, the service branch in which Blacks have been best represented. The total number of enlisted Blacks was 269,583, with just under half of them in the Army.

During the remainder of the 1970s, the numbers of Black enlistees rose dramatically, opening up a potential path to upward mobility for much larger numbers of African Americans. By 1980, 22.0 percent of all enlistees were Black, up from 14.0 percent just seven years earlier, with Black representation among enlistees in the Army rising to fully 32.9 percent. During the 1980 s, the total number of Black enlistees rose modestly, from about 387,000 in 1980 to 402,000 in 1990, bringing the proportion of enlistees who were Black to a peak of 23.2 percent. Since 1990, as the size of the military has been cut back, the number of Black enlistees has fallen steadily, to the point at which the total number of black enlistees in 2017 was just slightly over half the number in 1990. The proportion of Blacks among all Armed Forces enlistees declined from 23.2 percent in 1990 to 19.1 percent in 2017. Nevertheless, Blacks remained the demographic group most likely to serve in the military. ${ }^{115}$

\footnotetext{
112 Weitz et al., "Employment Mobility and the Belated Emergence of the Black Middle Class": "Black men were less likely to be granted medical exemptions, student deferments, or to become reservists or guardsmen. Blacks were more likely to be trained for combat, to be placed in low-level jobs, and to reenlist in order to gain a reenlistment bonus as a means of augmenting their family's income, thereby increasing their likelihood of serious physical and mental harm or death."

113 Ibid., p. 62.

114 Joshua D. Angrist, Stacey H. Chen, and Jae Song, "Long-term Consequences of Vietnam-Era Conscription: New Estimates Using Social Security Data," American Economic Review, 101, 3, 2011: 334-338; Mark C. Berger and Barry T. Hirsch, "The Civilian Earnings Experience of Vietnam-Era Veterans," Journal of Human Resources, 18, 4, 1983: 455-479.

115 Richard Reeves and Sarah Nzau, "Black Americans are much more likely to serve the nation, in the military and civilian roles." Brookings, August 27, 2020, at https://www.brookings.edu/blog/up-front/2020/08/27/black-americans-are-much-morelikely-to-serve-the-nation-in-military-and-civilian-roles/.
} 
Table IV.19: Black active enlisted members and officers in the U.S. Armed Forces, selected years, 1973-2017

\begin{tabular}{|c|c|c|c|c|}
\hline & \multicolumn{2}{|c|}{ All Armed Services } & \multicolumn{2}{c|}{ Army Only } \\
\cline { 2 - 5 } & $\begin{array}{c}\text { Number of } \\
\text { Blacks }\end{array}$ & $\begin{array}{c}\text { Blacks as \% } \\
\text { of total }\end{array}$ & $\begin{array}{c}\text { Number of } \\
\text { Blacks }\end{array}$ & $\begin{array}{c}\text { Blacks as \% } \\
\text { of total }\end{array}$ \\
\hline & \multicolumn{4}{|c|}{ Enlisted } \\
\hline $\mathbf{1 9 7 3}$ & 269,583 & 14.0 & 125,538 & 18.4 \\
\hline $\mathbf{1 9 7 7}$ & 317,463 & 17.8 & 178,945 & 26.3 \\
\hline $\mathbf{1 9 8 0}$ & 386,785 & 22.0 & 221,442 & 32.9 \\
\hline $\mathbf{1 9 8 5}$ & 385,864 & 21.1 & 198,981 & 29.9 \\
\hline $\mathbf{1 9 9 0}$ & 401,733 & 23.2 & 200,300 & 32.1 \\
\hline $\mathbf{1 9 9 5}$ & 276,806 & 21.8 & 127,056 & 30.1 \\
\hline $\mathbf{2 0 0 0}$ & 258,845 & 22.4 & 116,925 & 29.1 \\
\hline $\mathbf{2 0 0 5}$ & 228,731 & 19.9 & 96,872 & 23.9 \\
\hline $\mathbf{2 0 1 0}$ & 218,206 & 18.5 & 100,660 & 21.5 \\
\hline $\mathbf{2 0 1 5}$ & 204,442 & 19.1 & 94,423 & 24.1 \\
\hline $\mathbf{2 0 1 7}$ & 203,005 & 19.1 & 91,497 & 24.1 \\
\hline & & & & 11 \\
\hline $\mathbf{1 9 7 3}$ & 7,212 & 2.4 & 3,968 & 3.9 \\
\hline $\mathbf{1 9 7 7}$ & 10,001 & 3.9 & 5,185 & 6.1 \\
\hline $\mathbf{1 9 8 0}$ & 12,913 & 5.0 & 6,273 & 7.4 \\
\hline $\mathbf{1 9 8 5}$ & 18,458 & 6.4 & 9,666 & 10.2 \\
\hline $\mathbf{1 9 9 0}$ & 19,213 & 6.9 & 10,045 & 11.2 \\
\hline $\mathbf{1 9 9 5}$ & 16,195 & 7.4 & 7,980 & 11.3 \\
\hline $\mathbf{2 0 0 0}$ & 16,269 & 8.1 & 7,457 & 11.4 \\
\hline $\mathbf{2 0 0 5}$ & 18,232 & 8.7 & 8,611 & 12.5 \\
\hline $\mathbf{2 0 1 0}$ & 18,868 & 8.8 & 10,090 & 12.8 \\
\hline $\mathbf{2 0 1 5}$ & 17,719 & 8.4 & 9,347 & 11.7 \\
\hline $\mathbf{2 0 1 7}$ & 17,328 & 8.2 & 8,828 & 11.4 \\
\hline
\end{tabular}

Source: U.S. Department of Defense, Population

Representation in the Military Services, 2015, Table B-17, and 2017, Tables B-17, D-17, D36, at https://www .cna.org/research/pop-rep

It appears that since the 1980s Blacks have benefitted from military service in terms of subsequent civilian employment opportunity and earnings. As Angrist sums up his statistical study of U.S. military enlistees in the early 1980s:

The empirical results suggest that soldiers who served in the early 1980 s were paid considerably more than comparable civilians while in the military, and that military service is associated with higher employment rates for veterans after service. In spite of this employment gain, however, military service led to only a modest longrun increase in the civilian earnings of nonwhite veterans while actually reducing the civilian earnings of white veterans. ${ }^{116}$

116 Joshua Angrist, "Estimating the Labor Market Impact of Voluntary Military Service Using Social Security Data on Military Applicants," Econometrica, 66: 2, 1998: 249-288. 
A study by P. Wesley Routon of veterans who served during the time of the Afghanistan and Iraq wars finds that, subsequently in civilian employment, minority veterans had higher wages than similar non-veterans, but there was no difference for whites. Minorities and female veterans also increased their enrollment in college compared to minority and female non-veterans, with military financial benefits playing a significant role. The minority and female veterans primarily chose twoyear degrees rather than four-year degrees. ${ }^{117}$

Meredith Kleycamp also finds that Black veterans from the post-9/11 era had higher earnings their non-veteran counterparts, but that both Black and white veterans experienced higher rates of unemployment than comparable non-veterans. ${ }^{118}$ Kleycamp confirms the finding that veterans had higher rates of enrollment in college than comparable non-veterans. The enrollment effect was somewhat higher for whites.

The size of the differential in earnings due to military service varies across studies but is invariably modest. The largest effect among the studies reviewed was about 10 percent. The effect on enrollment in college was also estimated to be fairly small in size. Since 2008, much more generous financial benefits, including funding of higher education, have been available to veterans who served after September 11, 2001, and were discharged before January 1, 2013. The studies of veterans from this period show that Black men who had access to these benefits were significantly more likely to enroll in college. But, as we have seen in Table IV.19, what benefits there are to military service for increased earnings and college enrollment have accrued to a smaller and smaller number of Blacks since the 1980s, even as their proportional representation in the military has increased.

A long-term longitudinal study by W. Bradford Wilcox, Wendy R. Wang, and Ronald B. Mincy enhances the insights that can be drawn from the results of the research that we have reviewed. ${ }^{119}$ They use data from the National Longitudinal Survey of Youth for 1979, which began interviewing young men in 1979 when they were aged 14 to 22 and followed as many as possible with subsequent interviews. The authors look at the latest wave of data, taken in 2014, when the men were 50 to 58 years old. They separate the sample of Black men in the data in 2014 into three groups, those whose family income is in the middle third of the family income distribution in 2014, and who can hence be labeled "middle class"; those who are in poverty, measured by the federal poverty line; and those with other family income levels. They then analyze the situation of these Black men in 1979, when they were young, and the factors that are associated with making it to the middle class or are associated with falling into poverty.

As one might expect, going to college, being employed, and being married at age 22 increase the likelihood that a Black man will be in the middle class of income in 2014. Having served in the military also increases the likelihood that a Black man will make it to the middle class. The predicted effect is substantial. Wilcox et al. estimate that, controlling for other characteristics one

\footnotetext{
117 P. Wesley Routon, “The Effect of 21st Century Military Service on Civilian Labor and Educational Outcomes," Journal of Labor Research, 35, 2014: 15-38.

118 Meredith Kleykamp, “Unemployment, Earnings and Enrollment Among Post 9/11 Veterans,” Social Science Research, 42, 2013: 836-851.

${ }^{119}$ W. Bradford Wilcox, Wendy R. Wang, and Ronald B. Mincy, "Black Men Making It in America: The Engines of Economic Success for Black Men in America," Institute for Family Studies, American Enterprise Institute, 2018, at https://www.aei.org/research-products/report/black-men-making-it-in-america-the-engines-of-economic-success-for-blackmen-in-america/.
} 
might expect to be influential, the odds of making it to the middle class are 72 percent higher for Black men who served in the military, while military service cuts in half the odds of ending up in poverty. They explain that the effect of the military is mediated by its positive association with whether a young man is working or is married because both of these factors exert a strong influence on whether the man attains a middle-class income.

Following the end to conscription in 1973, Blacks also began to make progress moving up the ladder within the military. Their numbers increased and their proportional representation among officer ranks within the military rose markedly through the 1970s and have subsequently continued to rise. The lower panel of Table IV.19, above, shows the numbers and percentages of Black officers in all branches of the Armed Forces and in the Army over the period 1973-2017. In 1973, there were 7,212 active Black officers in all branches of the military, accounting for only 2.4 percent of all officers. Blacks were 3.9 percent of all officers in the Army, representing 55.0 percent of all Black officers in that year. The number of Black officers in the Armed Forces increased by 1.7 times from 1973 and 1990, as their percentage of the total increased by 2.9 times, from 2.4 percent to 6.9 percent. Even when the number of Black officers fell by over 3,000 from 1990 to 1995 , in the context of a substantial cutback in military spending, Blacks as a proportion of all officers increased to 7.4 percent. This proportion reached as high as 8.8 percent in 2010, although the number of Black officers in that year was less than in 1990.

While Blacks have been overrepresented as enlistees, they have been underrepresented as officers, although substantial progress has been made among the officer ranks since the 1970s. Black men have a higher percentage of officer assignments in the military, around eight percent, than they do in management and professional jobs in the non-military sectors, around four percent. ${ }^{120}$ Furthermore, in civilian employment, Black men have been more likely to find managerial and professional jobs in the government sector than the business sector, in which much more substantial barriers prevent Blacks from filling higher-level posts. ${ }^{121}$ Note that one needs to use some caution with this type of comparison because those individuals who decide to enter the military may be different from those who do not in ways that are not measured in these data.

Relatively higher representation by Black men as officers in the military than as professionals in the business sector notwithstanding, the military has had a history of difficult racial relations, persisting to the current time. There continue to be charges of discrimination, harassment, differential rates of discipline, and differential rates of promotion. ${ }^{122}$ Not surprisingly, the percentage of Black officers at the top ranks is lower than for officers as a whole. ${ }^{123}$ One problem is that a military-academy education increases the likelihood of becoming a high-ranking officer,

${ }^{120}$ Moss et al., "Employment and Earnings of African Americans Fifty Years After," Table II.3.

121 Weitz, et al., "Employment Mobility and the Belated Emergence of the Black Middle Class."

122 See, for example, Barry K. Robinson and Edgar Chen, "Déjà vu all over again: Racial disparity in the military justice system," Just Security, 2020 at https://www.justsecurity.org/72424/deja-vu-all-over-again-racial-disparity-in-the-militaryjustice-system/.

123 Irving Smith III, “Why Black Officers Still Fail,” U.S. Army War College, 2010: Table 1, at https://apps.dtic.mil/sti/pdfs/ADA538597.pdf; Kristy N. Kamarck, "Diversity, Inclusion, and Equal Opportunity in the Armed Services: Background and Issues for Congress," Congressional Research Service, June 9, 2019, Table 6, at https://fas.org/sgp/crs/natsec/R44321.pdf; Helene Cooper, "African-Americans are highly visible in the military, but almost invisible at the top," New York Times, June 9, 2020 at https://www.nytimes.com/2020/05/25/us/politics/military-minoritiesleadership.html. 
and the military academies were late in integrating. Complaints of racist treatment at West Point, for example, have recently come to the fore. ${ }^{124}$

In addition, qualitative research and attitude surveys from military personnel indicate that Black junior officers receive less mentorship than do white junior officers, and it is more difficult for them to be accepted into the officer culture and social networks that make referral and recommendations for promotion to higher rank more likely. ${ }^{125}$ We return in our next working paper in this study to the roles of culture and social networks in helping to explain the difficulties Blacks have had in penetrating high-technology industries, particularly in Silicon Valley.

\section{From mass production to mass incarceration}

Our discussion in this working paper has thus far centered on the declining availability of middleclass jobs for high-school-educated African Americans in business and government since the 1970s. We now turn to a separate but related set of questions. What new types of middle-class jobs have become available to high-school-educated Blacks in this period? And, more specifically, which jobs most closely approximate those lost with respect to wages, benefits, security, and the potential for intergenerational employment mobility?

The standard answer to these questions is well represented, as we noted at the beginning of this paper, in William Julius Wilson's classic monograph, When Work Disappears, published in 1996. As Wilson puts it, “...most of the new jobs for workers with limited training and education are in the service sector and are disproportionately held by women. This is even more true for those who work in social services, which include the industries of health, education, and welfare." ${ }^{126}$ Wilson's assessment remains largely accurate. However, over time it has become increasingly incomplete. As we document in Table II.6 of Working Paper No. 2, African Americans, particularly Black men, are not only disproportionately represented among those people subject to excessive policing and mass imprisonment; they are also overrepresented, in some cases dramatically, among the ranks of jailers, bailiffs, security guards, and police officers. These are the new semiskilled and skilled "blue collar" jobs in what we call "mass incarceration industries" (MII). With the growth of MII, Blacks are overrepresented as both jailers and jailed.

The mass movement of ethnic whites into middle-class business-sector jobs in the postwar era, particularly Irish Americans who had historically had high concentrations in municipal employment, opened space for Black workers to move into semiskilled positions in police departments. While the initial stages of this process preceded the widespread implementation of affirmative-action policies, its advent accelerated the flow of African Americans into the ranks of law enforcement. In the following decades, the socioeconomic restructuring of inner-city

\footnotetext{
124 Alex Horton, "A racial reckoning arrived at West Point, where being black is a 'beautifully painful experience'," Washington Post, July 10, 2020, at https://www.washingtonpost.com/national-security/2020/07/10/west-point-black-cadets/. Horton writes: "The academy takes the long view in minority admissions. In 1968, when the equal opportunity admissions office opened, only 68 African Americans had graduated since the U.S. Military Academy's founding in 1802...There were 72 black graduates in [the] Class of 2008...This year's incoming class saw 214 admitted African Americans out of 1,240 total cadets."

125 Smith, "Why Black Officers Still Fail"; Irving Smith (interview), "Lloyd Austin breaks 'brass ceiling' as first Black defense secretary,” PBS News Hour, January 22, 2021, at https://www .pbs.org/newshour/show/lloyd-austin-breaks-brass-ceiling-asfirst-black-defense-secretary; Horton, "A racial reckoning arrived at West Point"; Cooper "African Americans are highly visible."

${ }^{126}$ Wilson, When Work Disappears, p. 32.
} 
communities coincided with the HIV and crack epidemics to create a massive public health crisis. As federal, state, and local governments responded with increasingly punitive measures, workingclass Blacks found expanding employment opportunities in MII, particularly in state prisons and jails. Since the 1990s, the mass-incarceration complex of organizations and networks, involving politicians, prosecutors, correctional-officers unions, and prison-service companies, has exerted continuous political pressure to maintain the flow of funds into the system of mass incarceration, despite nearly twenty years of declining crime.

In 1996, Calvin J. Beale suggested that the combined effects of deindustrialization and rural prison expansion implied that the punishment of urban crime had become a "rural growth industry." 127 But it was not until the 2017 publication of James Forman, Jr.'s Locking Up Our Own that the employment of Blacks in the MII began to receive serious attention. ${ }^{128}$ The lack of serious consideration of Blacks working in MII is interesting in itself, given that a cursory review of prominent journalistic accounts of some of the major flashpoints of public debate-police brutality, the private prison industry, and the conditions of state and local prisons and jailsprovide an abundance of anecdotal evidence to illustrate the fact that African Americans from impoverished, inner-city communities are frequently found on opposing sides of the criminal justice system.

Reporting for the Washington Post, for example, the journalist Michael Fletcher remarked that Freddie Grey, who died of injuries sustained in the custody of Baltimore police, and one of the six arresting officers involved in his death, William G. Porter - both African Americans - "were born 11 blocks and less than two months apart in a city notoriously perilous for black males." ${ }^{29}$ In the PBS documentary, Rikers, former inmates Damien Stapleton and Marcell Neal are both quoted to similar effect. As Stapleton observes: "The majority of the officers on Rikers Island are minorities. They come from where we come from. They grew up where we grew up at. Somehow they just never made it to prison." Meanwhile, Neal states: "My aunts and my sister, captives on Rikers Island. And my dad and my mom, federal court officers." 130 And in an undercover investigation of the Winn Parish Correctional Center in Louisiana for Mother Jones, the journalist Shane Bauer comments: "Like the prisoners, the majority of the [correctional officers] at Winn are African American. More than half are women, many of them single moms." 131

How did MII come to supersede industrial manufacturing in the provision of viable employment options for working-class Blacks? The public unavailability of detailed historical EEO-4 data precludes charting the growth of black employment in mass incarceration in as granular a fashion as for the industries profiled in the Racial Policies of American Industry (RPAI) volumes, as we

${ }^{127}$ Calvin J. Beale, "Prisons, Populations and Jobs in Nonmetro America," Rural Development Perspectives, 8, 1, 1996: 6-19; see also Heather Ann Thompson, "The Prison Industrial Complex: A Growth Industry in a Shrinking Economy," New Labor Forum, 21, 3, 2012: 38-47; David F. Greenberg and Valerie West, "State Prison Populations and Their Growth, 1971-1991," Criminology, 39, 3, 2001: 615-654; and Rebecca U. Thorpe, "Perverse Politics: The Persistence of Mass Imprisonment in the Twenty-first Century," Perspectives on Politics, 13, 3, 2015: 618-637.

128 James Forman, Jr., Locking Up Our Own: Crime and Punishment in Black America, Farrar, Straus and Giroux, 2017.

${ }_{129}$ Michael A. Fletcher, "Freddie Gray and William Porter: Two sons of Baltimore whose lives collided," Washington Post, September 3, 2015, at https://www.washingtonpost.com/local/freddie-gray-and-william-porter-two-sons-of-baltimore-whoselives-collided/2015/09/03/a6273e5c-4a66-11e5-846d-02792f854297 story.html.

130 Damien Stapleton and Marcell Neal quoted in Rikers: An American Jail, produced by Mark Benjamin and Marc Levin, New York, Schumann Media Center Inc., 2016, minute 30:18-30:44 at https://www.pbs.org/video/rikers-rikers/.

131 Shane Bauer, American Prison: A Reporter's Undercover Journey into the Business of Punishment, Penguin Press, $2018, \mathrm{p}$. 43 
have done in Working Paper No. 3 of this series. ${ }^{132}$ However, available evidence suggests that mass-incarceration employment evolved along strikingly similar lines.

In outlining the growing presence of Blacks in state and local law enforcement, Forman draws on a series of studies of police departments in major U.S. cities. ${ }^{133}$ Nicholas Alex's ethnographic study of Black police officers in 1964-1965 New York City provides considerable insight in this regard. ${ }^{134}$ Alex highlights two factors that brought increasing numbers of Blacks into the ranks of the New York City police department. First, the long-standing distrust between Black inner-city residents and the police had come to be seen as a problem worthy of redress among politicians and government officials. The immediate causes of this change in attitude appear to have been the combined effects of pressure coming from the civil-rights movement and the practical need to reduce violence and social unrest following the wave of urban rebellions that included the Harlem riot of 1964. Second, in contrast to the late-nineteenth and early-twentieth centuries, during which time city officials could reliably draw on a vast pool of poor and working-class Irish Americans to staff police and fire departments, by the postwar era the big city political machines such as Tammany Hall were losing ground in local politics. Many Irish Americans had begun to seek and gain access to career-with-one-company (CWOC) employment in the growing business corporations. For many younger Irish Americans, the social networks that facilitated entry into police work had become tenuous. Meanwhile, for those with a college degree and access to better paying jobs in the business sector, municipal employment was now perceived as occupational stasis or decline. For Black workers, however, it represented a clear opportunity for gainful and secure employment. ${ }^{135}$ As one Black officer put it to Alex: "The reasons I became a policeman was simply two things: money and security."136

In the following years, the implementation and enforcement of affirmative action policies further facilitated the movement of African Americans into law enforcement. As Forman suggests, the founding of the National Organization of Black Police Executives in 1976 attests to the extent of the demographic change. ${ }^{137}$ But, as he details, increasing diversity in the 1970s was quickly followed by a severe public-health crisis across urban America. ${ }^{138}$ The widespread erosion of middle-class blue-collar jobs that we have documented contributed to the downward mobility that was central to the new urban crisis. In combination with the HIV epidemic, the proliferation of the crack trade, and the dismantling of New Deal and Great Society social programs, the collapse of gainful employment opportunities left many inner-city neighborhoods in a state of near-total social collapse.

Numerous research articles from the 1980 s to the present demonstrate the devastating socioeconomic consequences. ${ }^{139}$ Most notable among these, particularly in light of recent events,

${ }^{132}$ Weitz, et al., "Employment Mobility and the Belated Emergence of the Black Middle Class."

133 Forman, Locking Up Our Own, ch. 3.

${ }_{134}$ Nicholas Alex, Black in Blue: A Study of the Negro Policeman, Meredith Corporation, 1969.

135 Ibid., ch. 2; Steven P. Erie, Rainbow's End, Irish-Americans and the Dilemmas of Urban Machine Politics, 1840-1985, University of California Press, 1990, pp. 7-8.

136 Alex, Black in Blue, p. 38.

137 Forman, Locking Up Our Own, p. 114.

138 Ibid., chs. 4-6.

139 Gregory Pappas, Susan Queen, Wilbur Hadden, and Gail Fisher, "The Increasing Disparity in Mortality Between Socioeconomic Groups in the United States, 1960 and 1986," New England Journal of Medicine, 329, 2, 1993: 103-109; Kenneth D. Kochanek, Jeffrey D. Maurer, and Harry M. Rosenberg, "Why Did Black Life Expectancy Decline from 1984 through 1989 in the United States?," American Journal of Public Health, 84, 6, 1994: 938-944; Kim Hopper, Ezra Susser, 
was the unprecedented decline in Black life expectancy between 1984 and 1989, which the authors attribute to "...the negative impact of HIV infection, homicide, diabetes, and pneumonia..."140 Just as Anne Case and Angus Deaton argue that "the prescription of opioids for chronic pain added fuel to the flames" of cumulative job loss and social decay among working-class white communities today, in 1993 the criminologist Elliot Currie observed that "crack was like a match thrown on dry tinder," following the deindustrialization of America's inner cities. ${ }^{141}$

\section{Employment in Mass Incarceration Industries}

The political response to the social crisis of America's cities is now widely known. Rather than implementing a multi-faceted approach to community development, including long-term investment in education, housing, job training, and law enforcement, government officials pursued punitive measures with a near-singular focus. ${ }^{142}$ The rapid growth of prison and jail admissions in the 1980 s was followed in the 1990 s by a prison construction boom. ${ }^{143}$ Table IV.20 shows government-sector employment in mass-incarceration industries (MII) for 1982 to 2017. From 1982 to 1987 , the proportion of these MII employees in corrections rose from 24 percent to 34 percent, while the proportion in policing fell from 57 percent to 46 percent. Total employment in government-sector MII peaked in 2007 at a level nearly double the 1.3 million employees in 1982. There were substantial cutbacks in the Great Recession of 2007-2009, and from 2007 to 2017 the smallest percent reduction was in corrections.

and Sarah Conover, "Economies of Makeshift: Deindustrialization and Homelessness in New York City," Urban Anthropology and Studies of Cultural Systems and World Economic Development, 14, 1/3, 1985: 183-236; Peter H. Rossi and James D. Wright, "The Urban Homeless: A Portrait of Urban Dislocation," Annals of the American Academy of Political and Social Science, 501, 1, 1989: 132-142; Rick A. Matthews, Michael O. Maume, and William J. Miller, "Deindustrialization, Economic Distress, and Homicide Rates in Midsized Rustbelt Cities," Homicide Studies, 5, 2, 2001: 83-113; Tim Wadsworth, "Industrial Composition, Labor Markets, and Crime," Sociological Focus, 37, 1, 2004: 1-24; Eric D. Gould, "Torn Apart? The Impact of Manufacturing Employment Decline on Black and White Americans," Discussion Paper DP12992, Centre for Economic Policy Research, 2018.

${ }^{140}$ Kochanek et al, "Why Did Black Life Expectancy Decline," p. 943.

${ }^{141}$ Case and Deaton, "Mortality and Morbidity," p. 4; Elliot Currie, Reckoning: Drugs, the Cities, and the American Future, Hill \& Wang, 1993,p. 124.

${ }^{142}$ Forman, Locking Up Our Own; Jeremy Travis and Bruce Western, eds., The Growth of Incarceration in the United States: Exploring Causes and Consequences, The National Academies Press, 2014, ch. 4.

143 On the increase in admission rates, see Alfred Blumstein, “The Racial Disproportionality of United States' Prison Populations," Journal of Criminal Law \& Criminology, 73, 3, 1982: 1259-1281; Alfred Blumstein, "Racial Disproportionality of U.S. Prison Populations Revisited," University of Colorado Law Review, 64, 1993: 743-760; Thomas P. Bonczar, "Prevalence of Imprisonment in the U.S. Population, 1974-2001," Bureau of Justice Statistics, 2003, at https://www.bjs.gov/content/pub/pdf/piusp01.pdf; Alfred Blumstein and Allen J. Beck, "Population Growth in U.S. Prisons, 1980-1996," Crime and Justice, 26, 1999: 17-61; on the prison building boom, see John Eason, "Mapping Prison Proliferation: Region, Rurality, Race and Disadvantage in Prison Placement," Social Science Research, 39, 2010: 1015-1028; Sarah Lawrence and Jeremy Travis, "The New Landscape of Imprisonment: Mapping America's Prison Expansion,” Urban Institute, 2004, at http://www.urban .org/research/publication/new-landscape-imprisonment. 
Table IV.20: Government-sector employment in massincarceration industries by function, 19822017

\begin{tabular}{|c|c|c|c|c|}
\hline & Total & Judicial & Police & Corrections \\
\hline & \multicolumn{4}{|c|}{ Number of employees } \\
\hline 1982 & $1,270,342$ & 247,697 & 723,923 & 298,722 \\
\hline 1987 & $1,524,976$ & 312,331 & 792,831 & 419,814 \\
\hline 1992 & $1,797,704$ & 373,611 & 857,593 & 566,500 \\
\hline 1997 & $2,078,192$ & 419,072 & 950,877 & 708,243 \\
\hline 2002 & $2,304,201$ & 488,841 & $1,065,078$ & 750,280 \\
\hline 2007 & $2,450,195$ & 508,985 & $1,163,412$ & 777,798 \\
\hline 2012 & $2,118,073$ & 432,346 & 970,976 & 714,751 \\
\hline \multirow[t]{2}{*}{2017} & $2,144,392$ & 440,129 & 984,957 & 719,306 \\
\hline & \multicolumn{4}{|c|}{ Percentage of total employment } \\
\hline 1982 & 100.0 & 19.5 & 57.0 & 23.5 \\
\hline 1987 & 100.0 & 20.5 & 52.0 & 27.5 \\
\hline 1992 & 100.0 & 20.8 & 47.7 & 31.5 \\
\hline 1997 & 100.0 & 20.2 & 45.8 & 34.1 \\
\hline 2002 & 100.0 & 21.2 & 46.2 & 32.6 \\
\hline 2007 & 100.0 & 20.8 & 47.5 & 31.7 \\
\hline 2012 & 100.0 & 20.4 & 45.8 & 33.7 \\
\hline \multirow[t]{2}{*}{2017} & 100.0 & 20.5 & 45.9 & 33.5 \\
\hline & \multicolumn{4}{|c|}{ Percent change in employment } \\
\hline 1982-2007 & 92.9 & 105.5 & 60.7 & 160.4 \\
\hline 2007-2017 & -12.5 & -13.5 & -15.3 & -7.5 \\
\hline
\end{tabular}

Note: Employment includes both full-time and part-time employees

Source: U.S. Census Bureau, Annual Survey of Public Employment \& Payroll (ASEP), Datasets \& Tables, at https://www .census.gov/programssurveys/apes/data/datasetstables.html.

Recall again the data on non-blue-collar occupations with high representation of Blacks from Table II.4 of our Working Paper No. 2. ${ }^{144}$ Table IV.21 compares median weekly wage and mean annual salary data for selected occupations with high rates of Black representation in mass incarceration and assorted industries. Aside from postal service clerks, social workers, and licensed practical and vocational nurses, few mass service-sector jobs outside the criminal justice system offer remuneration comparable to semiskilled work in the MII. Our review of cross-industry employment growth in Working Paper No. 3 showed that high-school-educated Blacks made the greatest gains from unskilled to semiskilled employment in firms and industries that were experiencing high levels of growth, that were geographically clustered near majority-Black communities, and for which they had sufficient education and training to qualify. ${ }^{145}$ If the Racial Policies of American Industries studies are any guide, we should observe similar patterns in the MII as well.

\footnotetext{
${ }^{144}$ Moss et al., "Employment and Earnings of African Americans

${ }^{145}$ Weitz et al., "Employment Mobility and the Belated Emergence of the Black Middle Class."
} 


\section{Table IV.21: Median hourly wages and mean annual salaries for high-Black-representation occupations in mass- incarceration and selected non-mass-incarceration occupations, May 2018}

\begin{tabular}{|c|c|c|}
\hline & $\begin{array}{c}\text { Median } \\
\text { hourly } \\
\text { wage, \$ }\end{array}$ & $\begin{array}{c}\text { Mean } \\
\text { annual } \\
\text { salary, \$ }\end{array}$ \\
\hline \multicolumn{3}{|l|}{ Mass-Incarceration Occupations } \\
\hline First-Line Supervisors of Correctional Officers & 30.45 & 68,350 \\
\hline Police Officers & 29.56 & 65,460 \\
\hline Probation Officers and Correctional Treatment Specialists & 25.49 & 58,790 \\
\hline Bailiffs & 22.00 & 49,870 \\
\hline Correctional Officers and Jailers & 21.31 & 49,300 \\
\hline \multicolumn{3}{|l|}{ Selected Non-Mass Incarceration Occupations } \\
\hline Postal Service Clerks & 26.58 & 50,860 \\
\hline Social Workers & 23.79 & 53,060 \\
\hline Licensed Practical and Licensed Vocational Nurses & 22.23 & 47,050 \\
\hline Miscellaneous Healthcare Support Occupations & 16.63 & 35,830 \\
\hline Phlebotomists & 16.58 & 35,560 \\
\hline Bus Drivers & 16.56 & 36,280 \\
\hline Security Guards and Gaming Surveillance Officers & 13.72 & 32,090 \\
\hline Nursing, Psychiatric, and Home Health Aides & 12.89 & 28,180 \\
\hline Taxi Drivers and Chauffers & 12.49 & 28,450 \\
\hline Cooks & 12.12 & 26,560 \\
\hline Personal Care Aides & 12.06 & 25,090 \\
\hline Retail Salespersons & 11.63 & 28,310 \\
\hline Cashiers & 10.78 & 23,240 \\
\hline
\end{tabular}

Source: U.S. Bureau of Labor Statistics, "National Occupational

Employment and Wage Estimates, United States May 2018," at https://www.bls.gov/oes/current/oes nat.htm\#33-0000

Note: Annual salary is based on 2,080 hours.

We now trace in greater detail the process by which African Americans came to be overrepresented in mass-incarceration occupations. Because of problems with data availability and the distribution of Black occupational representation, we restrict our analysis to, first, police and, second, corrections.

\section{Police Employment}

Samuel Walker's 1989 study used EEO-4 data on police employment in the 50 largest cities in the United States between 1983 and 1988 to assess the extent of demographic change. Overall, Walker found uneven growth in minority employment across departments. As a result of municipal budget cuts and an entrenched seniority system, many departments were simply not in a position to bring Black officers into their ranks. ${ }^{146}$ Others, meanwhile, experienced substantial gains, including 13

\footnotetext{
${ }^{146}$ Samuel Walker, "Employment of Black and Hispanic Police Officers, 1983-1988: A Follow-Up Study,” Occasional Paper No. 89-1, Center for Applied Urban Research, 1989, p. 7.
} 
departments which saw "an increase of 50.0 percent or more in the representation of black officers between 1983 and 1988." ${ }^{147}$

Figure IV.3 shows comparative data collected by David Sklansky on the percent of Black officers in selected city departments for available years in the 1960s and the year 2000. ${ }^{148}$ Comparing municipal employment data in America's largest cities in 1967 and 2000, Sklansky observes substantial growth in the percentage of minority police officers, with some cities undergoing shifts of over 60 percentage points, as occurred in Detroit and Washington, D.C. ${ }^{149}$ In Sklansky's view, "the overwhelming weight of the evidence suggests affirmative action played a pivotal role in the diversification of American police departments." ${ }^{150}$ Justin McCrary estimates that court-ordered affirmative action quotas caused an overall increase of 14 percent more Black police officers between 1960 and 1999. ${ }^{151}$

\section{Figure IV.3: Black officers as a percent of total officers in select major city departments, 1960s and 2000}

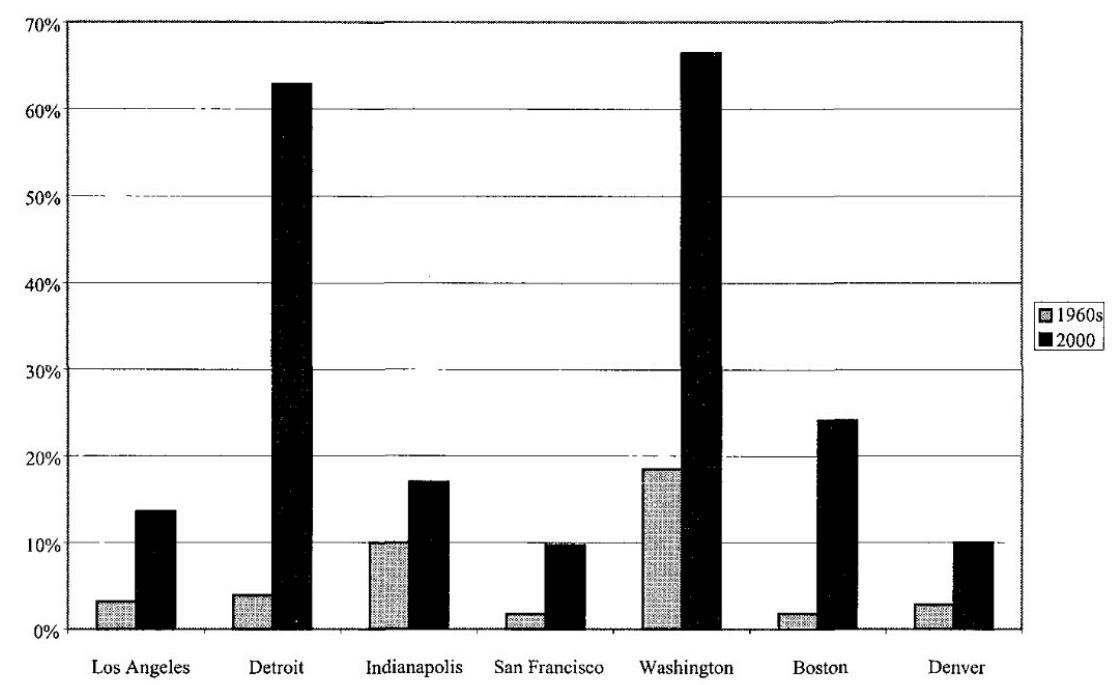

Source: Sklansky, “Not Your Father’s Police Department,” p. 1216.

A recent report by the Department of Justice and EEOC reflects similarly uneven growth in minority employment across police departments. Analyzing data from 1987 to 2013, the authors found that Blacks remain underrepresented relative to their local population in 60 percent of the 1,061 police departments studied. ${ }^{152}$ But while individual cases vary, in aggregate, as of 2013, Blacks comprised 12.2 percent of local police department employment, which is about the same percentage of the representation of Black workers in the U.S. economy. ${ }^{153}$ And as Figure IV .4

\footnotetext{
${ }^{147}$ Ibid., pp. 2-3.

148 David Alan Sklansky, "Not Your Father's Police Department: Making Sense of the New Demographics of Law Enforcement," Journal of Criminal Law \& Criminology, 96, 3, 2005: 1209-1244

149 Ibid., p. 1214.

${ }^{150}$ Ibid., p. 1235.

151 Justin McCrary, "The Effect of Court-Ordered Hiring Quotas on the Composition and Quality of Police," American Economic Review, 97, 1, 2007: 318-353.

152 Vanita Gupta and Jenny Yang, “Advancing Diversity in Law Enforcement,” US Department of Justice, 2016, pp. 13-14; see also Will Miller, Brinck Kerr, and Margaret Reid, "Descriptive Representation by Gender and Race/Ethnicity in Municipal Bureaucracies: Change in US Multiethnic Cities, 1987-2001," Journal of Women, Politics, \& Policy, 31: $217-242$.

${ }^{153}$ Gupta and Yang, "Advancing Diversity in Law Enforcement," p. 11.
} 
shows, between 1987 and 2016, racial and ethnic minorities working in police departments with fifty or more employees nearly doubled their total representation, increasing from 15 to 27 percent of all employees in the dataset. Thus, while demographic parity within the majority of police departments remains elusive, overall and in a selection of departments (particularly larger ones), there has been a notable increase in Black officers.

Figure IV.4: Percent minority employment in local police departments, 1987-2016

14

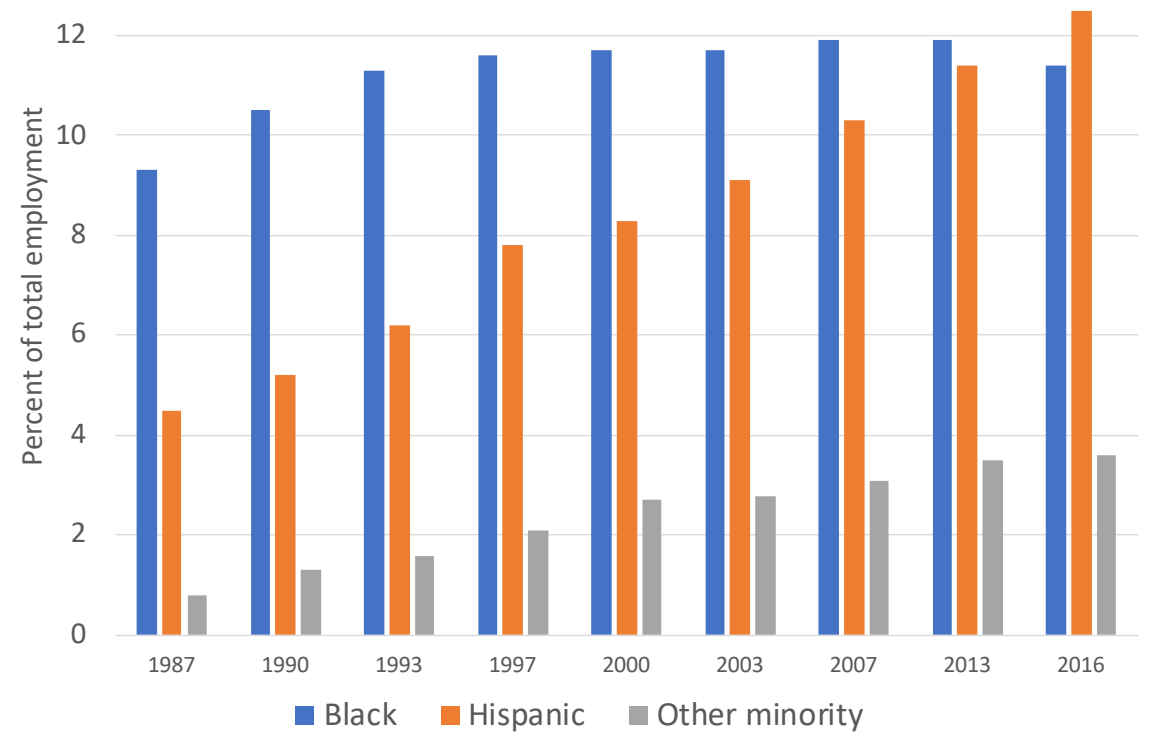

Note: "Other minority" includes Asians, Native Hawaiians, Other

Pacific Islanders, American Indians, Alaska Natives, or persons of two or more races. Beginning in 2013, the LEMAS survey included the option for respondents to indicate "two or more races" for law enforcement personnel.

Source: U.S. Bureau of Justice Statistics, Law Enforcement Management and Administrative Statistics survey, "Local Police Departments, Personnel, 2013," Bulletin, May 2015 (for 1987-2013), at https://www.bjs.gov/content/pub/pdf/lpd13ppp.pdf, and "Local Police Departments, Personnel, 2016," Bulletin, October 2019 (for 2016), at https://www.bjs.gov/content/pub/pdf/lpd16p.pdf.

\section{Corrections Employment}

While corrections employment is the second largest category in the government-sector massincarceration industry, it underwent the highest rate of employment growth. Following the rapid increase in jail admissions and incarceration rates in the 1980s, the 1990s saw a substantial prison 
construction boom. ${ }^{154}$ The proliferation of new prison jobs created opportunity for corrections employment for high-school-educated workers seeking upward mobility.

Table IV.22 shows historical data on corrections employment from 1984 to 2005. While we are aware of no previous use of EEO-4 data disaggregated by race/ethnicity, gender, and occupational category, the Census of State and Federal Adult Correctional Facilities series does permit us to trace general trends. And in combination with other available sources, a clearer, if still blurred, picture emerges.

Table IV.22: State and federal adult correctional facility employment by race/ethnicity and gender, 1984-2005

\begin{tabular}{|l|r|r|r|r|r|c|}
\hline \multirow{2}{*}{} & \multicolumn{7}{|c|}{ Correctional facility employment } \\
\cline { 2 - 7 } & 1984 & 1990 & $1995^{*}$ & 2000* & 2005* & $\begin{array}{c}\text { \% change, } \\
\mathbf{1 9 8 4 - 2 0 0 5}\end{array}$ \\
\hline Race/ethnicity & & & & & & \\
\hline White, non-Hispanic & 108,459 & 187,093 & 228,211 & 264,900 & 244,322 & 125 \\
\hline Black, nonHispanic & 25,134 & 49,226 & 62,495 & 78,739 & 76,285 & 204 \\
\hline Hispanic & 5,219 & 13,148 & 20,317 & 30,105 & 22,080 & 323 \\
\hline Other & 2,147 & 3,930 & 6,422 & 7,601 & 7,066 & 229 \\
\hline Gender & & & & & & \\
\hline Male & 112,457 & 190,564 & 241,315 & 278,725 & 296,852 & 164 \\
\hline Female & 28,502 & 62,833 & 97,675 & 135,189 & 148,203 & 420 \\
\hline
\end{tabular}

* Data are restricted to "confinement facilities", which includes prisons, prison hospitals, boot camps, and alcohol/drug treatment centers. Data exclude "community-based" facilities, such as halfway houses and work release centers. Because the distinction among correctional facilities is not made for previous years, data may slightly underestimate employment increases from 1984.

Source: U.S. Bureau of Justice Statistics, "Census of State and Federal Adult Correctional Facilities Series," at https://www.bjs.gov/index.cfm?ty=dcdetail\&iid=255.

Between 1984 and 2005 there was a net increase of 51,000 Black workers who found employment in correctional facilities, an increase of 204 percent over 21 years. Meanwhile, Hispanic employees increased by 323 percent and the percentage female employees grew by 420 percent. For nonHispanic whites and males, these increases were 125 percent and 164 percent, respectively. The most common perspective on prison employment holds that, on the whole, whites living in rural communities disproportionately benefit from corrections employment, while Blacks and Hispanics from metropolitan areas are disproportionately found in the ranks of the incarcerated. ${ }^{155}$ Available data support this contention in absolute terms, but the data in Table IV .22 show that by 2005 the corrections labor force had become much more diversified over the previous two decades. As of 2015, Blacks comprised 26 percent of U.S. corrections officers compared to 37 percent of the U.S.

\footnotetext{
${ }^{154}$ On arrest and incarceration rates see Travis and Western., The Growth of Incarceration, in the United States, ch.2; on prison expansion and construction see Eason, "Mapping Prison Proliferation"; Lawrence and Travis, "The New Landscape of Imprisonment."

155 See, e.g., Thorpe, "Perverse Politics"; Rachel Gandy, "In prison, Blacks and Latinos do the time Whites get the jobs," Prison Policy Initiative, July 10, 2015, at https://www.prisonpolicy.org/blog/2015/07/10/staff disparities/.
} 
prison population. ${ }^{156}$ With Blacks making up 12 percent of the U.S. population, Blacks are substantially overrepresented among corrections employees as well as prison inmates.

We have seen that Black entry into police employment has tended to concentrate in large, municipal departments where employee turnover and growth were pronounced. In a study of prison expansion, however, John Eason shows that 70 percent of all rural prison construction in this period took place in poor regions of the South, with higher-than-average representation of Black and Hispanic residents. ${ }^{157}$ In a recent analysis of inmate and correctional staff demographics for the Prison Policy Initiative, Rachel Gandy shows that according to 2005 data from the Census of State and Federal Adult Correctional Facilities, correctional facilities with demographic parity for Blacks are overwhelmingly concentrated in the South, with additional pockets found in the post-industrial metropolitan areas of the Northeast, Midwest, and West Coast (see Figure IV.5). Likewise, correctional facilities in which Hispanics hold demographic parity between jailers and jailed are overwhelmingly concentrated in the southwest. Taken together, these studies strongly suggest that, particularly relative to their shares in the total population, the mass expansion of correctional facilities from the 1980s through the 2000s was a growth industry for Blacks as much as for whites.

Figure IV. 5: Correctional facilities disaggregated by demographic parity, 2005

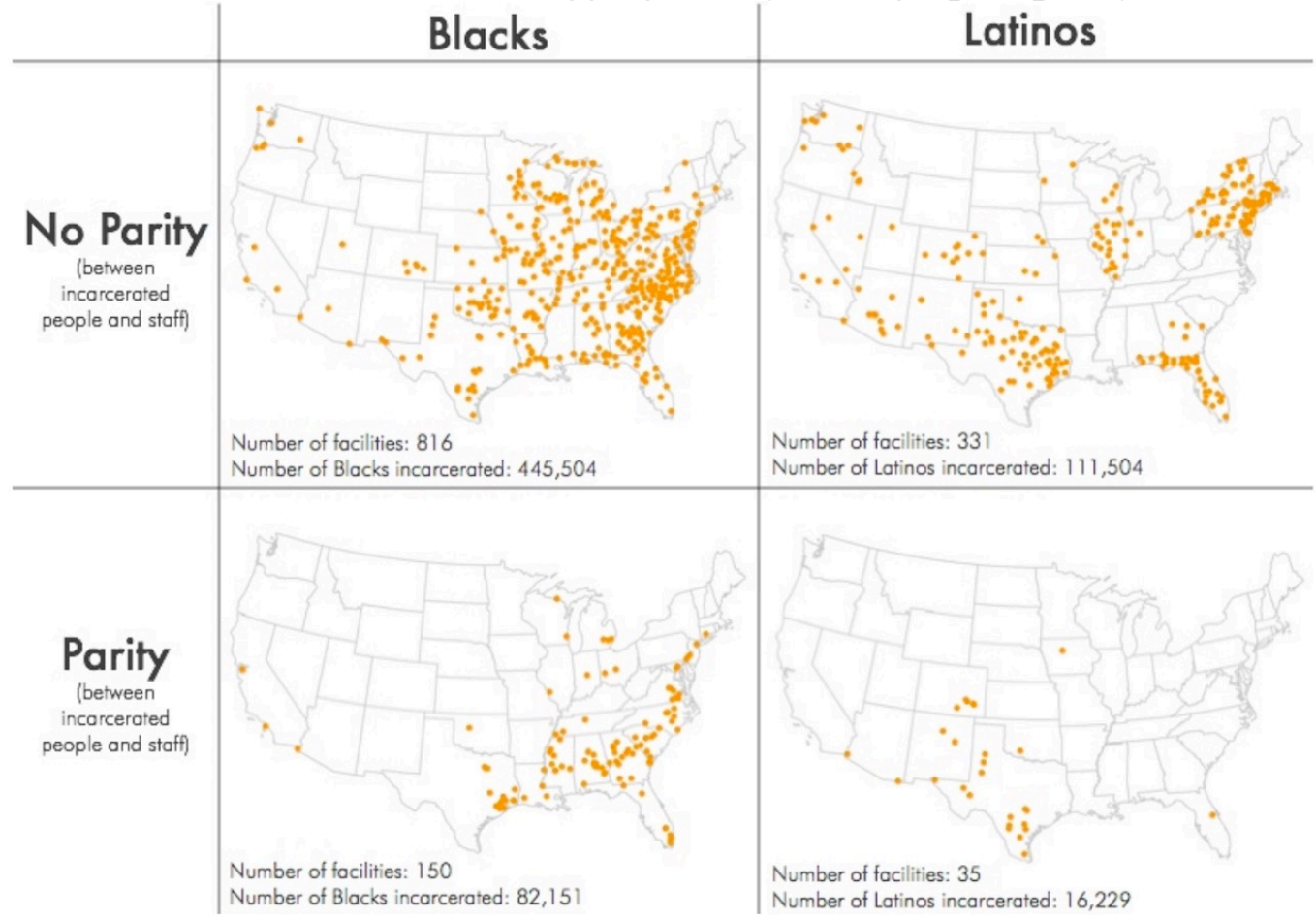

Source: Gandy, "In prison.”

An important implication of Black overrepresentation in MII is that many Black police and correctional officers, the latter in particular, have formed an important interest group opposing progressive criminal justice reform and promoting punitive policies as a guarantor of

\footnotetext{
156 Austin McCoy, "Prison Guard Unions and Mass Incarceration: Prospects for an Improbable Alliance," New Labor Forum, 26, 1, 2017: 74-83, at p. 77.

157 Eason, "Mapping Prison Proliferation," p. 1025.
} 
employment. ${ }^{158}$ As Joshua Page notes of the California Correctional Peace Officers Association (CCPOA), perhaps the most influential correctional officers union in the nation, the growth of California's prison system gave the CCPOA an increasingly large supply of manpower, money, and political clout. And while the CCPOA has used its influence to defend the system of mass incarceration and attack potential reform efforts, as its ranks diversified in the 1990s CCPOA came to embrace racial/ethnic minorities and women, supporting numerous "ethnic- and gender-based criminal justice organizations, including the Association of Black Correctional Workers, the Chicano Correctional Workers Association, and the Women Peace Officers Association of California... [as well as promoting] Hispanic and African American Officers to its own leadership positions." 159

Recent efforts to plan the closure of the Rikers Island jail in New York City underscore this point. The Correction Officers' Benevolent Association (COBA) has operated as a formidable obstacle. As reported in the New York Times, under the leadership of the now-imprisoned former COBA president Norman Seabrook:

...corrections officers, long overlooked among the city's uniformed services, have seen large gains in salary and pension benefits, reaching parity with firefighters and police officers. Like Mr. Seabrook, the overwhelming majority of his members are black. They have risen to dominate the top ranks of the department, making it far more diverse than the Police and Fire Departments, where most of the leadership is white. ${ }^{160}$

\section{Implications}

There currently exists a wealth of literature documenting the deleterious effects of mass incarceration on the socioeconomic prospects for the incarcerated, their families, and communities. ${ }^{161}$ But what are the implications of Black overrepresentation as employees in MII for current and future employment mobility? In concluding this discussion, we suggest that the weight of the evidence points toward serious obstacles to the kind of intergenerational career mobility that has been at the center of our analysis. We also argue that Black overrepresentation in MII holds implications for any policy initiatives aimed at reducing the number of incarcerated

158 See John Pfaff, Locked In: The True Causes of Mass Incarceration and How to Achieve Real Reform, Basic Books, 2017, ch.3, for a general discussion of government-sector mass incarceration industry interest-group influence.

159 Joshua Page, "Prison Officer Unions and the Perpetuation of the Penal Status Quo," Criminology \& Public Policy, 10, 3, 2011: 735-770, at p. 742.

160 Michael Schwirtz and Michael Winerip, “At Rikers Island, union chief's clout is a roadblock to reform," New York Times, December 14, 2014, at https://www.nytimes.com/2014/12/15/nyregion/at-rikers-a-roadblock-to-reform.html?module=inline. See also Benjamin Weiser and Zoe Greenberg, "Norman Seabrook was once a union power broker in New York. Now he is going to prison," New York Times, February 8, 2019, at https://www.nytimes .com/2019/02/08/nyregion/seabrooksentencing.html

161 See, in particular, Bruce Western, Jeffrey R. King, and David F. Weiman, "The Labor Market Consequences of Incarceration," Crime \& Delinquency, 47, 1, 2001: 410-427; Bruce Western, "The Impact of Incarceration on Wage Mobility and Inequality," American Sociological Review, 67, 4, 2002: 526-546; Bruce Western and Becky Pettit, "Black-White Wage Inequality, Employment Rates, and Incarceration," American Journal of Sociology, 111, 2, 2005: 553-578; Devah Pager, Marked: Race, Crime, and Finding Work in an Era of Mass Incarceration, University of Chicago Press, 2008; Darren Wheelock, Christopher Uggen, and Heather Hlavka, "Employment Restrictions for Individuals with Felon Status and Racial Inequality in the Labor Market," in Ikponwosa Ekunwe and Richard S. Jones, eds., Global Perspectives on Re-entry, Tampere University Press, 2011: 278-310. For a general review of literature see Travis and Western, The Growth of Incarceration in the United States, ch. 8. 
in the absence of additional measures to offset lost income and job security. In other words, should prison reform movements succeed in dismantling the system of mass incarceration but fail to provide middle-class employment alternatives for displaced workers and the formerly incarcerated, these initiatives may actually cause a further reduction in Black socioeconomic status.

We have already discussed how prison construction came to be seen as a source of economic growth by state and local officials in the 1980s and 1990s. But while politicians and distressed workers came to perceive correctional facilities as such, available research suggests this view is inaccurate. Although prison employment may help to reduce poverty in depressed, rural communities, the effect of prison construction on communities as a whole appears to be negligible, and perhaps even counterproductive. ${ }^{162}$ Gregory Hooks and his coauthors, for example, find "no evidence that prison construction stimulates economic growth." 163 They suggest further that rural prison construction may impede regional growth by crowding out public budgets required to provide a variety of essential services, such as electrical and transportation infrastructure, thereby limiting the capacity of state and local governments to support the construction and maintenance of alternative investments and attract more fruitful employers from the business sector. ${ }^{164}$

A second issue arises when considering this question with reference to the historical experience of the Irish in America. The majority of Irish Americans remained confined to the lower-middle class until the postwar era, when the big city political machines they relied on for employment collapsed and middle-class jobs became available in the business sector. In the approximate period between the Civil Rights Act of 1964 and the rise of mass incarceration in the 1980s, African Americans who gained access to government-sector jobs were largely concentrated in social services. As we have shown, however, the growth of the MII has altered this pattern, seeing important gains in large municipal police departments and even greater levels of employment growth in correctional facilities. While these jobs provide many Black workers greater income and security than other viable employment options, they may, as they did for many Irish Americans, entail the additional consequence of impeding the development of an upwardly mobile Black middle class by concentrating employment in lower-status jobs. ${ }^{165}$

The growth of Black employment in MII, as with much of government-sector employment, also leaves Black workers vulnerable to the future transformation of government resulting from changes in the distribution of political power. We previously outlined how policy changes beginning in the 1980s reduced the government-sector opportunity structure for upwardly mobile Blacks. We see no reason why mass-incarceration jobs may not become subject to similar downsizing should sufficient political will arise. The calls to "defund the police" by Black Lives Matter activists in the aftermath of the police murder of George Floyd is a case in point. As we noted previously, while the number of Black and Hispanic police officers has grown considerably over the past half century, white officers continue to dominate leadership positions in the majority of police departments and unions. Should police departments undergo significant downsizing, it is

\footnotetext{
162 Amy K. Glasmeier and Tracey Farrigan, "The Economic Impacts of the Prison Development Boom on Persistently Poor Rural Places," International Regional Science Review, 30, 3, 2007: 274-299.

${ }^{163}$ Gregory Hooks, Clayton Mosher, Thomas Rotolo, and Linda Lobao, "The Prison Industry: Carceral Expansion and Employment in U.S. Counties, 1969-1994," Social Science Quarterly, 85, 1, 2004: 37-57, at p. 37.

164 Ibid., p. 54.

165 See Steven P. Erie, "Two Faces of Ethnic Power: Comparing the Irish \& Black Experiences," Polity, 13, 2, 1980: 261-284, at p. 269.
} 
likely that those officers who lack seniority and occupy lower ranking positions will be most likely to face reduced working hours, salary cuts, or layoffs.

Mass incarceration has been a powerfully destructive force in American society. Yet the evidence that we have outlined also points to the simple fact that many Black workers and their families have become as dependent on these jobs as they have in other areas of high-Black representation, such as healthcare, social welfare, and education. The rise and persistence of mass incarceration can largely be explained by the decisions of political leaders to pursue punitive policies disproportionately in the face of a massive public health crisis, rooted in part in the disappearance of the Black blue-collar middle class. Any policies aimed at reversing the system of mass incarceration must provide the comprehensive approach, long demanded across Black communities, to the creation of new middle-class employment opportunities - ones designed to serve the socioeconomic needs of African Americans rather than jobs that all too often reflect America's persistent denial that Black lives matter. 


\section{Bibliographic references:}

Abowd, John M., George T. Milkovich, and John M. Hannon, "The Effects of Human Resource Management Decisions on Shareholder Value," Industrial and Labor Relations Review, 43, Special Issue: 1990: 203S-233S

Alex, Nicholas, Black in Blue: A Study of the Negro Policeman, Meredith Corporation, 1969.

Alexander, Brian, Glass House: The 1\% Economy and the Shattering of the All-American Town, St. Martin's Press, 2017.

Andrews, Greg, "State's labor force subtly shifting to small business," Indianapolis Business Journal, September 2, 1991.

Angrist, Joshua, "Estimating the Labor Market Impact of Voluntary Military Service Using Social Security Data on Military Applicants," Econometrica, 66: 2, 1998: 249-288.

Angrist, Joshua D., Stacey H. Chen, and Jae Song, "Long-term Consequences of Vietnam-Era Conscription: New Estimates Using Social Security Data," American Economic Review, 101, 3 , 2011: 334-338.

Anon., "Car union tries to flex muscles on Mercedes Drive, Financial Times, September 16, 1999.

Anon., "GM's top negotiator says automakers considering two-tier wages," Associated Press, May 28, 1987.

Anon., "Metro Areas with Largest African American Population,' Black Demographics, African American Population Report, at http://blackdemographics.com/population/black-citypopulation/.

Anon., "Military history of African Americans," Wikipedia, at https://en.wikipedia.org/wiki/Military_history_of_African_Americans.

Anon., "Racial segregation in the United States Armed Forces, Wikipedia, at https://en.wikipedia.org/wiki/Racial segregation in the United States Armed Forces.

Anon., "Racism against African Americans in the U.S. military," Wikipedia, at https://en.wikipedia.org/wiki/Racism against African Americans in the U.S. military.

Anon., "UAW moves again to organize Nissan assembly plant in Tennessee," Associated Press, June 19, 1997.

Barkholz, David, "For Detroit 3 and UAW, the last gap with transplants," Automotive News, March 14, 2011.

Barkholz, David, and Jamie LaReau, "UAW puts GM on Toyota's heels," Automotive News, October 1, 2007.

Bauer, Shane, American Prison: A Reporter's Undercover Journey into the Business of Punishment, Penguin Press, 2018.

Bawden, D. Lee, and John L. Palmer, "Social Policy: Challenging the Welfare State," in John L. Palmer and Isabel Sawhill, eds., The Reagan Record: An Assessment of America's Changing Domestic Priorities, Ballinger, 1984: 177-216 
Beale, Calvin J., "Prisons, Populations and Jobs in Nonmetro America," Rural Development Perspectives, 8, 1, 1996: 6-19.

Bednarzik, Robert W., "Layoffs and Permanent Job Losses: Workers' Traits and Cyclical Patterns," Monthly Labor Review, September 1983: 3-12.

Benjamin, Daniel K., "Voluntary Export Restraints on Automobiles, PERC, 17, 3, 1999, at https://www.perc.org/1999/09/01/voluntary-export-restraints-on-automobiles/.

Benjamin, Mark, and Marc Levin, producers, Rikers: An American Jail, New York, Schumann Media Center Inc., 2016, at https://www.pbs.org/video/rikers-rikers/.

Berger, Mark C., and Barry T. Hirsch, "The Civilian Earnings Experience of Vietnam-Era Veterans," Journal of Human Resources, 18, 4, 1983: 455-479.

Blumstein, Alfred, "Racial Disproportionality of U.S. Prison Populations Revisited," University of Colorado Law Review, 64, 1993: 743-760.

Blumstein, Alfred, “The Racial Disproportionality of United States' Prison Populations," Journal of Criminal Law \& Criminology, 73, 3, 1982: 1259-1281.

Blumstein, Alfred, and Allen J. Beck, "Population Growth in U.S. Prisons, 1980-1996," Crime and Justice, 26, 1999: 17-61.

Bonczar, Thomas P., "Prevalence of Imprisonment in the U.S. Population, 1974-2001," Bureau of Justice Statistics, 2003, at https://www.bjs.gov/content/pub/pdf/piusp01.pdf.

Bradsher, Keith, "Union moves to hold vote at Nissan plant in Tennessee," New York Times, August 15, 2001, at https://www.nytimes.com/2001/08/15/business/union-moves-to-hold-voteat-nissan-plant-in-tennessee.html.

Bragman, Aaron, "U.S. Big Three make progress in manufacturing productivity; but Japanese companies still lead,” IHS Global Insight, June 1, 2007.

Braunstein, Janet, "GM's first contract proposal not well-received by UAW," Associated Press, August 12, 1987.

Bridge, Adrian, and Larry Black, "BMW defies union over South Carolina plant," Independent, August 3, 1992.

Brown, Warren, “Iacocca, rights groups attack Japanese companies' hiring," Washington Post, November 8, 1990.

Bureau of Labor Statistics, "Employment, Hours, and Earnings from the Current Employment Statistics Survey (National)," data gathered August 19, 2018, at https://data.bls.gov/timeseries/CEU3133600108?amp\%253bdata tool=XGtable\&output view=d ata\&include graphs=true.

Burgelman, Robert A., "Fading Memories: A Process Theory of Strategic Business Exit in Dynamic Environments," Administrative Science Quarterly, 39, 1, 1994: 24-56.

Case, Anne, and Angus Deaton, "Mortality and Morbidity in the $21^{\text {st }}$ Century," and "Comments and Discussion," Brookings Papers on Economic Activity, Spring 2017: 397-476.

Chandler, Jr., Alfred D., Inventing the Electronic Century: The Epic Story of the Consumer Electronics and Computer Industries, Free Press, 2001. 
Chetty, Raj, David Grusky, Maximilian Hell, Nathanial Hendren, Robert Manduca, and Jimmy Narang, "The Fading American Dream: Trends in Absolute Income Mobility since 1940," Science, 356, 6336, 2017: 398-406.

Clark, Kim B., and Takahiro Fujimoto, Product Development Performance: Strategy, Organization, and Management in the World Auto Industry, Harvard Business School Press, 1991.

Cole, Robert E., and Donald R. Deskins, Jr. "Racial Factors in Site Location and Employment Patterns of Japanese Auto Firms in America," California Management Review, 31, 1, 1988: 9-22.

Conrad, Cecilia A., "Changes in the Labor Market Status of Black Women, 1960-2000," in Cecilia A. Conrad, John Whitehead, Patrick Mason, and James Stewart, eds. African Americans in the U.S. Economy, Rowman \& Littlefield, 2005: 157-162.

Conrad, Cecilia A., and Mary C. King, "Single-Mother Families in the Black Community: Economic Context and Policies," in Cecilia A. Conrad, John Whitehead, Patrick Mason, and James Stewart, eds. African Americans in the U.S. Economy, Rowman \& Littlefield, 2005: 163 174.

Cooper, David, Mary Gable, and Algernon Austin "The public-sector jobs crisis: Women and African Americans hit hardest by job losses in state and local governments," Economic Policy Institute Briefing Paper \#339, May 2012.

Cooper, Helene, "African-Americans are highly visible in the military, but almost invisible at the top,“"New York Times, June 9, 2020 at https://www.nytimes.com/2020/05/25/us/politics/militaryminorities-leadership.html.

Currie, Elliot, Reckoning: Drugs, the Cities, and the American Future, Hill \& Wang, 1993.

DePillis, Lydia, "Volkswagen workers reject UAW in Tenn.; Union looks for Plan B to enter South," Washington Post, February 15, 2014.,at https://www.washingtonpost.com/business/economy/volkswagen-workers-reject-uaw-in-tennunion-looks-for-plan-b-to-enter-south/2014/02/15/c35c018c-967c-11e3-9616d367fa6ea99b_story.html?utm_term=.9aa7470d74a4;

Dodsworth, Terry, "UAW suffers defeat at Honda plant: Union loses tactical battle at US subsidiary of motor company," Financial Times, Match 19, 1986.

Douglas-Gabrielle, Danielle, "Harvard agrees to negotiate a contract with graduate-student union," Washington Post, May 1, 2018, at https://www.washingtonpost.com/news/gradepoint/wp/2018/05/01/harvard-agrees-to-negotiate-a-contract-with-graduate-studentunion/?utm term=.d99391eb4bb1.

Eason, John, "Mapping Prison Proliferation: Region, Rurality, Race and Disadvantage in Prison Placement," Social Science Research, 39, 2010: 1015-1028.

Eder, Steve, "UAW workers' pay on par with Japanese competitors in U.S.," The Blade, December 13, 2008.

EEODataNet, University of Massachusetts Amherst, at https://www.umass.edu/eeodatanet/home.

Eisenstein, Paul A., "GM's housecleaning goes beyond closings," Michigan Business, April 1, 1987. 
Ellwood, David, and Jonathan Crane, "Family Change Among Black Americans: What Do We Know?" Journal of Economic Perspectives, 4, 4, 1990: 65-84.

Erie, Steven P., "Two Faces of Ethnic Power: Comparing the Irish \& Black Experiences," Polity, 13, 2, 1980: 261-284, at p. 269.

Erie, Steven P., Rainbow's End: Irish-Americans and the Dilemmas of Urban Machine Politics, 1840-1985, University of California Press, 1990.

Fairlie, Ronald, and Lori Kletzer, "Jobs Lost, Jobs Regained: An Analysis of Black/White Differences in Job Displacement in the 1980s," Industrial Relations, 37, 4, 1998: 460-477.

Farnsworth, Clyde, “Car imports: Hints for Japan,” New York Times, March 24, 1981.

Fletcher, Michael A., "Freddie Gray and William Porter: Two sons of Baltimore whose lives collided," Washington Post, September 3, 2015, at

https://www.washingtonpost.com/local/freddie-gray-and-william-porter-two-sons-of-baltimorewhose-lives-collided/2015/09/03/a6273e5c-4a66-11e5-846d-02792f854297_story.html.

Ford Motor Company, Annual Reports, 1979-2001.

Forman, Jr., James, Locking Up Our Own: Crime and Punishment in Black America, Farrar, Straus and Giroux, 2017.

Freeman, Richard B., The Overeducated American, Academic Press, 1976.

Gandy, Rachel, "In prison, Blacks and Latinos do the time Whites get the jobs," Prison Policy Initiative, July 10, 2015, at https://www.prisonpolicy.org/blog/2015/07/10/staff disparities/.

Gardner, Greg, and Brent Snavely, "UAW, FCA officials miscalculated young worker angst," Detroit Free Press, October 5, 2015, at https://www.freep.com/story/money/cars/chrysler/2015/10/03/uaw-fca-officials-miscalculatedyoung-worker-angst-united-auto-workers/73291332/.

Gene Gruver, Frank Giarratani, and Randall Jackson, “Clusters, Agglomeration, and Economic Development Potential: Empirical Evidence Based on the Advent of Slab Casting by U.S. Steel Minimills," Economic Development Quarterly, 21,2, 2007: 148 -164.

Gilmore, Gerry J., "African-Americans continue tradition of distinguished service," U.S. Army News Service, Feb. 2, 2007, at

https://www.army.mil/article/1681/african_americans_continue_tradition_of_distinguished_servi ce.

Glasmeier, Amy K., and Tracey Farrigan, "The Economic Impacts of the Prison Development Boom on Persistently Poor Rural Places," International Regional Science Review, 30, 3, 2007: 274-299.

Glasser, Susan B., and Glenn Thrush, "What's going on with America's white people?" Politico, September/ October 2016, at https://www.politico.com/magazine/story/2016/09/problems-whitepeople-america-society-class-race-214227;

Goolsbee, Austan D., and Alan B. Krueger, "A Retrospective Look at Rescuing and Restructuring General Motors and Chrysler," Journal of Economic Perspectives, 29, 2, 2015: 223. 
Gould, Eric D., “Torn Apart? The Impact of Manufacturing Employment Decline on Black and White Americans," Discussion Paper DP12992, Centre for Economic Policy Research, 2018.

Greenberg, David F., and Valerie West, "State Prison Populations and Their Growth, 19711991," Criminology, 39, 3, 2001: 615-654.

Gupta, Vanita, and Jenny Yang, “Advancing Diversity in Law Enforcement," US Department of Justice, 2016.

Hamermesh, Daniel S., "What Do We Know About Worker Displacement in the U.S.?"

Industrial Relations, 28, 1, 1989: 51-59

Hanley, Robert, "Last Ford leaves Mahwah plant; 4,500 employees lose their jobs," New York Times, June 21, 1980, at https://timesmachine.nytimes.com/timesmachine/1980/06/21/111248141.html?pageNumber=1.

Harkinson, Josh, "Silicon Valley firms are even whiter and more male than you thought," Mother Jones, May 29, 2014, at https://www.motherjones.com/media/2014/05/google-diversitylabor-gender-race-gap-workers-silicon-valley/.

Harris, Candee S., "The Magnitude of Job Loss from Plant Closings and the Generation of Replacement Jobs: Some Recent Evidence," Annals of the American Academy of Political and Social Science, 475, 1984: 15-27.

Harrison, Bennett, "Ghetto Employment and the Model Cities Program," Journal of Political Economy. 82, 2, Part 1, 1974: 353-371.

Healey, James R., "Profit-sharing checks top \$1,700 at Honda," USA Today, November 23, 1990.

Hogan, Lloyd, and Harry Harris, “The Occupational-Industrial Structure of Black Employment in the United States," Review of Black Political Economy, 6, 1, 1975.

Holusha, John, “U.A.W. pledges to organize employees at Japanese plants in U.S., New York Times, June 8, 1986.

Hooks, Gregory, Clayton Mosher, Thomas Rotolo, and Linda Lobao, "The Prison Industry: Carceral Expansion and Employment in U.S. Counties, 1969-1994," Social Science Quarterly, 85, 1, 2004: 37-57.

Hopper, Kim, Ezra Susser, and Sarah Conover, "Economies of Makeshift: Deindustrialization and Homelessness in New York City," Urban Anthropology and Studies of Cultural Systems and World Economic Development, 14, 1/3, 1985: 183-236.

Horton, Alex, "A racial reckoning arrived at West Point, where being black is a 'beautifully painful experience'," Washington Post, July 10, 2020, at https://www.washingtonpost.com/national-security/2020/07/10/west-point-black-cadets/.

Howard, Phoebe Wall, "Many of UAW's newest members aren't traditional autoworkers," Detroit Free Press, April 14, 2020, at https://www.freep.com/story/money/cars/2020/04/14/uawmembership-2019/2923908001/.

Jackson, Kathy, "UAW concedes defeat at transplants - for now," Automotive News, April 27, 1998.

Judge, Paul C., “UAW faces test at Mazda plant,” New York Times, March 27, 1990. 
Kalafsky, Ronald V., and Alan D. MacPherson, "The Competitive Characteristics of U.S. Manufacturers in the Machine Tool Industry," Small Business Economics, 19, 4, 2002: 354-369.

Kamarck, Kristy N., "Diversity, Inclusion, and Equal Opportunity in the Armed Services: Background and Issues for Congress," Congressional Research Service, June 9, 2019, at https://fas.org/sgp/crs/natsec/R44321.pdf.

Kashefi, Javad, and Gilbert J. McKee, "Stock Prices’ Reactions to Layoff Announcements," Journal of Business and Management, 8, 2, 2002: 99-107.

Kenney, Martin, and Richard Florida, Beyond Mass Production: The Japanese System and Its Transfer to the United States, Oxford University Press, 1993.

Kevin-Myers, Bridget, and Russ Hembree, “The Hancock Amendment: Missouri's Tax Limitation Measure," Missouri Legislative Academy, Institute of Public Policy, University of Missouri, November 2012, at https://ruman.missouri.edu/sites/default/files/publication/17-2012hancock-amendment.pdf.

Kiley, David, "Foreign companies cast long shadow on UAW negotiations," USA Today, August 3, 2003.

Kletzer, Lori, “Job Displacement,” Journal of Economic Perspectives, 12, 1, 1998: 115-136

Kleykamp, Meredith, "Unemployment, Earnings and Enrollment Among Post 9/11 Veterans," Social Science Research, 42, 2013: 836-851.

Kochanek, Kenneth D., Jeffrey D. Maurer, and Harry M. Rosenberg, "Why Did Black Life Expectancy Decline from 1984 through 1989 in the United States?," American Journal of Public Health, 84, 6, 1994: 938-944.

Laing, Keith, and Ian Thibodeau, "UAW membership dropped by 35,000 in 2018," Detroit News, March 29, 2019, at https://www .detroitnews.com/story/business/autos/2019/03/29/uawmembership-dropped-last-year/3314861002/.

Lawrence, Sarah, and Jeremy Travis, “The New Landscape of Imprisonment: Mapping America's Prison Expansion," Urban Institute, 2004, at http://www.urban.org/research/publication/new-landscape-imprisonment.

Lazonick, William, "Book review of Glass House: the 1\% and the Shattering of the AllAmerican Town," Industrial and Labor Relations Review, 70, 5, 2017: 1285-1287.

Lazonick, William, Competitive Advantage on the Shop Floor, Harvard University Press, 1990.

Lazonick, William, "Innovative Business Models and Varieties of Capitalism: Financialization of the US Corporation," Business History Review, 84, 4, 2010: 675-702.

Lazonick, William, "Organizational Learning and International Competition," in Jonathan Michie and John Grieve Smith, eds., Globalization, Growth, and Governance, Oxford University Press, 1998: 204-238

Lazonick, William, “The Institutional Triad and Japanese Development” [translated into Japanese] in Glenn Hook and Akira Kudo, eds., The Contemporary Japanese Enterprise, Yukikaku Publishing, 2005, Volume 1: 55-82. 
Lazonick, William, and Matt Hopkins, "GM's Stock Buyback Is Bad for America and the Company," Harvard Business Review, March 11, 2015, at https://hbr.org/2015/03/gms-stockbuyback-is-bad-for-america-and-the-company.

Lazonick, William, and Tony Huzzard, "Why everyone does better when employees have a say in the workplace," OUPBlog, April 30, 2014, at https://blog.oup.com/2014/04/automobilemanufacturing-employee-voice/

Mahler, Jonathan, "G.M., Detroit and the fall of the black middle class," New York Times, June 28, 2009, at http://www.nytimes.com/2009/06/28/magazine/28detroit-t.html.

Mair, Andrew, Richard Florida, and Martin Kenney, "The New Geography of Automobile Production: Japanese Transplants in North America," Economic Geography, 64, 4, 1988: 352373.

Matthews, Rick A., Michael O. Maume, and William J. Miller, "Deindustrialization, Economic Distress, and Homicide Rates in Midsized Rustbelt Cities," Homicide Studies, 5, 2, 2001: 83113.

McCoy, Austin, "Prison Guard Unions and Mass Incarceration: Prospects for an Improbable Alliance," New Labor Forum, 26, 1, 2017: 74-83.

McCrary, Justin, "The Effect of Court-Ordered Hiring Quotas on the Composition and Quality of Police," American Economic Review, 97, 1, 2007: 318-353.

McElroy, John, “Don't kiss UAW goodbye just yet," Ward's Autoworld, August 1, 2010.

McKinney, Kathy, "Diamond-Star UAW race won by challenger,” The Pantagraph, June 6, 1991.

Milkman, Ruth, Farewell to the Factory: Auto Workers in the Late Twentieth Century, University of California Press, 1997.

Miller, Will, Brinck Kerr, and Margaret Reid, "Descriptive Representation by Gender and Race/Ethnicity in Municipal Bureaucracies: Change in US Multiethnic Cities, 1987-2001," Journal of Women, Politics, \& Policy, 31: 217-242.

Moran, Larry R., “Motor Vehicles. Model Year 1990,” Survey of Current Business, 70, 11, 1990.

Moss, Philip, William Lazonick, and Joshua Weitz, "Employment and Earnings of African Americans Fifty Years After: Progress?" Institute for New Economic Thinking Working Paper No. 129. July 13, 2020, at https://www.ineteconomics.org/research/research-papers/employmentand-earnings-of-african-americans-fifty-years-after-progress.

Nissan Public Relations, "Nissan to celebrate ten years in Tennessee," PRNewswire, October 24, 1990.

Okimoto, Daniel I., and Yoshio Nishi, "R\&D Organization in Japanese and American Semiconductor Firms," in Masahiko Aoki and Ronald Dore, eds., The Japanese Firm: The Sources of Competitive Strength, Oxford University Press, 1994: 178-208.

Organisation Internationale des Constructeurs d'Automobiles (OICA), "Production statistics," 1999-2016, at http://www.oica.net/production-statistics/.

Page, Joshua, "Prison Officer Unions and the Perpetuation of the Penal Status Quo,"

Criminology \& Public Policy, 10, 3, 2011: 735-770. 
Pager, Devah, Marked: Race, Crime, and Finding Work in an Era of Mass Incarceration, University of Chicago Press, 2008.

Palmon, Oded, Huey-Lian Sun, and Alex P. Tang, "Layoff Announcements: Stock Market Impact and Financial Performance," Financial Management, 26, 3, 1997: 54-68

Pappas, Gregory, Susan Queen, Wilbur Hadden, and Gail Fisher, "The Increasing Disparity in Mortality Between Socioeconomic Groups in the United States, 1960 and 1986," New England Journal of Medicine, 329, 2, 1993: 103-109.

Patterson, Gregory A., "Nissan workers reject by 2-1 margin UAW bid to organize Tennessee plant," Wall Street Journal, July 28, 1989.

Pfaff, John, Locked In: The True Causes of Mass Incarceration-and How to Achieve Real Reform, Basic Books, 2017.

Pil, Frits K., and John Paul MacDuffie, "What Makes Transplants Thrive: Managing the Transfer of 'Best Practice' at Japanese Auto Plants in North America," Journal of World Business, 34, 4, 1999: 372-391.

Platzer, Michaela D., and Glennon J. Harrison, "The U.S. Automotive Industry: National and State Trends in Manufacturing Employment," Congressional Research Service, R40746, 2009, at http://digitalcommons.ilr.cornell.edu/key workplace/666.

Plunkert, Lois M., "The 1980s: A Decade of Job Growth and Industry Shifts," Monthly Labor Review, September 1990: 3-16, at https://www.bls.gov/opub/mlr/1990/09/art1full.pdf.

President Harry S. Truman, Executive Order 9981, "Desegregation of the Armed Forces," July 26, 1948; General Records of the United States Government; Record Group 11; National Archives, at https://www .ourdocuments.gov/doc.php?flash=false\&doc=84.

Reeves, Richard, and Sarah Nzau, "Black Americans are much more likely to serve the nation, in the military and civilian roles." Brookings, August 27, 2020, at

https://www.brookings.edu/blog/up-front/2020/08/27/black-americans-are-much-more-likely-toserve-the-nation-in-military-and-civilian-roles/.

Robinson, Barry K., and Edgar Chen, "Déjà vu all over again: Racial disparity in the military justice system," Just Security, 2020 at https://www.justsecurity.org/72424/deja-vu-all-overagain-racial-disparity-in-the-military-justice-system/ .

Rossi, Peter H., and James D. Wright, "The Urban Homeless: A Portrait of Urban Dislocation," Annals of the American Academy of Political and Social Science, 501, 1, 1989: 132-142.

Rothstein, Jeffrey S., When Good Jobs Go Bad: Globalization, De-unionization, and Declining Job Quality in the North American Auto Industry, Rutgers University Press, 2016.

Routon, P. Wesley, “The Effect of 21st Century Military Service on Civilian Labor and Educational Outcomes," Journal of Labor Research, 35, 2014: 15-38.

Rubenstein, James M., "Changing Distribution of the American Automobile Industry," Geographical Review, 76, 3, 1986: 288-300.

Rubenstein, James M., "Further Changes in the American Automobile Industry," Geographical Review, 77, 3, 1987: 359-362. 
Ruckelshaus, Catherine, and Sarah Leberstein, "Manufacturing Low Pay: Declining Wages in the Jobs That Built America's Middle Class," National Employment Law Project, November 2014, at https://www.nelp.org/publication/manufacturing-low-pay-declining-wages-in-the-jobsthat-built-americas-middle-class/.

Rueben, Kim S., and Megan Randal, "Tax and Expenditure Limits: How States Restrict Revenues and Spending," Urban Institute, November 27, 2017.

Salamon, Lester M., "Non-Profit Organizations: The Lost Opportunity," in John L. Palmer and Isabel V. Sawhill, eds., The Reagan Record: An Assessment of America's Changing Domestic Priorities, The Urban Institute, 1984:

Scheiber, Norm, "Nissan workers in Mississippi reject union bid by U.A.W," New York Times, August 5, 2017.

Schmitt, John, and Ben Zipperer, "The Decline of African-American Representation in Unions and Manufacturing, 1979-2007," Center for Economic Policy and Research Issue Brief, February 2008.

Schwirtz, Michael, and Michael Winerip, “At Rikers Island, union chief's clout Is a roadblock to reform," New York Times, December 14, 2014, at

https://www.nytimes.com/2014/12/15/nyregion/at-rikers-a-roadblock-toreform.html?module=inline.

Serrin, William, “A growing despair in Detroit: Jobless rates rise as car sales fall," New York Times, December 13, 1979, at http://www.nytimes.com/1979/12/13/archives/a-growing-despairin-detroit-jobless-rates-rise-as-car-sales-fall.html.

Sharpe, Rochelle, "Losing ground: In latest recession, only blacks suffered net employment loss," Wall Street Journal, September 14, 1993, A1.

Sharpe, Rochelle, "Unequal opportunity: Losing ground on the employment front," Wall Street Journal, September 14, 1993: A12-A13.

Shepardson, David, "UAW says membership rose 1.8 percent in 2016," Reuters, April 4, 2017 , at https://www.reuters.com/article/us-usa-labor/uaw-says-membership-rose-1-8-percent-in-2016idUSKBN177047

Shepherd, David, and Christine Tierney, "King ups pressure on auto transplants," Detroit News, January 13, 2011.

Singleton, Christopher J., "Auto Industry Jobs in the 1980's: A Decade of Transition," Monthly Labor Review, February 1992: 18-27.

Sklansky, David Alan, "Not Your Father's Police Department: Making Sense of the New Demographics of Law Enforcement," Journal of Criminal Law \& Criminology, 96, 3, 2005: 1209-1244.

Smith, Irving, PBS News Hour interview, "Lloyd Austin breaks 'brass ceiling' as first Black defense secretary," January 22, 2021, at https://www.pbs.org/newshour/show/lloyd-austinbreaks-brass-ceiling-as-first-black-defense-secretary.

Smith III, Irving, "Why Black Officers Still Fail,” U.S. Army War College, 2010: Table 1, at https://apps.dtic.mil/sti/pdfs/ADA538597.pdf.Stanford, Jim, “The Geography of Auto 
Globalization and the Politics of Auto Bailouts," Cambridge Journal of Regions, Economy, and Society, 3, 3, 2010: 383-405.

Smith, James P., and Finis R. Welch, "Black-White Male Wage Ratios: 1960-70," American Economic Review, 67, 3, 1977: 323-338.

Stein, Lana, "Privatization, Work-Force Cutbacks, and African-American Municipal Employment,"American Review of Public Administration. 24, 2, 1994: 181-186.

Stein, Robert L., and Janice Neipert Hedges, "Blue-Collar/White-Collar Pay Trends: Earning and Family Income," Monthly Labor Review, 94, 6, 1971: 13-24.

Swift, Mike, "Blacks, Latinos, and women lose ground at Silicon Valley tech companies," Mercury News, February 11, 2010, at https://www.mercurynews.com/2010/02/11/blacks-latinosand-women-lose-ground-at-silicon-valley-tech-companies/.

Swoboda, Frank, "UAW election no victory for confrontation," Washington Post, November 10, 1991.

Szczensy, Joseph R., "Third wage tier gains foothold at four GM plants," Wards Auto, March 30, 2015, at https://www.wardsauto.com/industry/third-wage-tier-gains-foothold-four-gm-plants

Thiede, Brian C., and Shannon M. Monnat, “The Great Recession and America's Geography of Unemployment," Demographic Research, 30, Article 35, 2016: 891-928.

Thompson, Heather Ann, "The Prison Industrial Complex: A Growth Industry in a Shrinking Economy," New Labor Forum, 21, 3, 2012: 38-47.

Thorpe, Rebecca U., "Perverse Politics: The Persistence of Mass Imprisonment in the Twentyfirst Century," Perspectives on Politics, 13, 3, 2015: 618-637.

Travis, Jeremy, and Bruce Western, eds., The Growth of Incarceration in the United States: Exploring Causes and Consequences, The National Academies Press, 2014.

U.S. Bureau of Justice Statistics, "Census of State and Federal Adult

Correctional Facilities Series," at https://www.bjs.gov/index.cfm?ty=dcdetail\&iid=255.

U.S. Bureau of Justice Statistics, Law Enforcement Management and Administrative Statistics survey, "Local Police Departments, Personnel, 2013," Bulletin, May 2015, at https://www.bjs.gov/content/pub/pdf/lpd13ppp.pdf.

U.S. Bureau of Justice Statistics, Law Enforcement Management and Administrative Statistics survey, "Local Police Departments, Personnel, 2016," Bulletin, October 2019, at https://www.bjs.gov/content/pub/pdf/lpd16p.pdf.

U.S. Bureau of Labor Statistics, "National Occupational Employment and

Wage Estimates, United States May 2018," at https://www.bls.gov/oes/current/oes_nat.htm\#33-0000

U.S. Bureau of Labor Statistics, "State and Area Employment Hours and Earnings (SIC) (Not seasonally adjusted)," Current Employment Statistics, at https://data.bls.gov/pdq/SurveyOutputServlet.

U.S. Bureau of the Census, Statistical Abstract of the United States, 1980, $101^{\text {st }}$ edition, U.S. Government Printing Office, 1980. 
U.S. Census Bureau, Statistical Abstract of the United States, 1984, 105 ${ }^{\text {th }}$ edition, Government Printing Office, 1984.

U.S. Bureau of the Census, "The Black Population: 2010," 2010 Census Briefs, C2010BR-06, September, 2011, at https://www .census.gov/prod/cen2010/briefs/c2010br-06.pdf

U.S. Census Bureau, Annual Survey of Public Employment \& Payroll (ASEP), Datasets \& Tables, at https://www.census.gov/programs-surveys/apes/data/datasetstables.html.

U.S. Council of Economic Advisers, The Economic Report of the President 2000, Government Printing Office 2000.

U.S. Council of Economic Advisers, The Economic Report of the President 2016, Government Printing Office 2016.

U.S. Department of Commerce, Bureau of the Census, Statistical Abstract of the United States 1984, 104 ${ }^{\text {th }}$ edition, U.S. Government Printing Office, 1983.

U.S. Department of Commerce, Bureau of the Census, Statistical Abstract of the United States 1987, 107 th edition, U.S. Government Printing Office, 1986.

U.S. Department of Defense, Population Representation in the Military

Services, 2015, at https://www.cna.org/research/pop-rep.

U.S. Equal Employment Opportunity Commission, "EEO-1: Who Must File”, at https://www.eeoc.gov/employers/eeo1survey/whomustfile.cfm.

U.S. Equal Employment Opportunity Commission, "Job Patterns for Minorities and Women in Private Industry," various years, at https://www.eeoc.gov/eeoc/statistics/employment/jobpat-eeo1/.

Uchitelle, Louis, "Diminishing expectations: 'Two-tier' union contracts have opened a gulf between generations," The Nation, February 25, 2013: 18-20.

United Auto Workers, "UAW grows by almost 15,000 new members in 2017; 75,000 new members since 1979," UAW news release, March 29, 2018, at https://uaw .org/uaw-growsalmost-15000-new-members-2017-75000-new-members-since-2009/

United Auto Workers, "UAW Grows by Almost 15,000 New Members in 2017; 75,000 New Members Since 2009," UAW News Release, March 29, 2018, at https://uaw.org/uaw-growsalmost-15000-new-members-2017-75000-new-members-since-2009/.

Vellequette, Larry P., "VW workers at Tenn. plant reject second UAW organizing bid," Automotive News, June 19, 2019, at https://www.autonews.com/manufacturing/vw-workerstenn-plant-reject-second-uaw-organizing-bid.

Wadsworth, Tim, "Industrial Composition, Labor Markets, and Crime," Sociological Focus, 37, 1, 2004: 1-24.

Waldman, Peter, “Inside Alabama's auto jobs boom: Cheap wages, little training, crushed limbs," Bloomberg Businessweek, March 23, 2017, at

https://www.bloomberg.com/news/features/2017-03-23/inside-alabama-s-auto-jobs-boom-cheapwages-little-training-crushed-limbs.

Walker, Samuel, "Employment of Black and Hispanic Police Officers, 1983-1988: A Follow-Up Study," Occasional Paper No. 89-1, Center for Applied Urban Research, 1989. 
Weil, David, The Fissured Workplace: Why Work Became So Bad for So Many and What Can Be Done to Improve it, Harvard University Press, 2017.

Weiser, Benjamin, and Zoe Greenberg, "Norman Seabrook was once a union power broker in New York. Now he Is going to prison," New York Times, February 8, 2019, at https://www.nytimes.com/2019/02/08/nyregion/seabrook-sentencing.html

Weitz, Joshua, William Lazonick, and Philip Moss, "Employment Mobility and the Belated Emergence of the Black Middle Class," Institute for New Economic Thinking Working Paper No. 143, January 2, 2021, at https://www.ineteconomics.org/research/researchpapers/employment-mobility-and-the-belated-emergence-of-the-black-middle-class.

Welch, David, and David Phillips, “Automakers, UAW open contract talks," Salt Lake Tribune, June 15, 1999.

Westcott, Diane Nilsen, "Blacks in the 1970's: Did They Scale the Job Ladder," Monthly Labor Review, 105, 6, 1982: 29-38.

Western, Bruce, “The Impact of Incarceration on Wage Mobility and Inequality," American Sociological Review, 67, 4, 2002: 526-546.

Western, Bruce, and Becky Pettit, "Black-White Wage Inequality, Employment Rates, and Incarceration," American Journal of Sociology, 111, 2, 2005: 553-578.

Western, Bruce, Jeffrey R. King, and David F. Weiman, “The Labor Market Consequences of Incarceration," Crime \& Delinquency, 47, 1, 2001: 410-427.

Wheelock, Darren, Christopher Uggen, and Heather Hlavka, "Employment Restrictions for Individuals with Felon Status and Racial Inequality in the Labor Market," in Ikponwosa Ekunwe and Richard S. Jones, eds., Global Perspectives on Re-entry, Tampere University Press, 2011: 278-310.

Wilcox, W. Bradford, Wendy R. Wang, and Ronald B. Mincy, "Black Men Making It in America: The Engines of Economic Success for Black Men in America," Institute for Family Studies, American Enterprise Institute, 2018, at https://www .aei.org/research-

products/report/black-men-making-it-in-america-the-engines-of-economic-success-for-blackmen-in-america/.

Wilson, William Julius, The Declining Significance of Race: Blacks and Changing American Institutions, University of Chicago Press, 1978.

Wilson, William Julius, “When Work Disappears,” Political Science Quarterly, 111, 4, 1996-97: 567-595.

Wilson, William Julius, When Work Disappears: The World of the New Urban Poor, Vintager Books, 1996.

Wilson, William Julius, and Kathryn Neckerman, "Poverty and Family Structure: The Widening Gap between Evidence and Public Policy Issues," in Sheldon Danziger and Daniel Weinberg, eds., Fighting Poverty: What Works and What Doesn't, Harvard University Press: 232-259.

Wood, Robert G., "Marriage Rates and Marriageable Men: A Test of the Wilson Hypothesis," Journal of Human Resources, 5, 20, 1995: 163-193. 
Woodward, Douglas P., "Locational Determinants of Japanese Manufacturing Start-Ups in the United States," Southern Economic Journal, 58, 3, 1992: 690-708. 